\title{
ISOLAMENTO, CARACTERIZAÇÃO GENÉTICA POR RAPD E RESISTÊNCIA A ANTIBIÓTICOS EM Xylella fastidiosa
}

\section{PAULO TEIXEIRA LACAVA}

Engenheiro Agrônomo

Orientador: Prof. Dr. JOÃO LÚCIO DE AZEVEDO

Dissertação apresentada à Escola Superior de Agricultura "Luiz de Queiroz", Universidade de São Paulo, para obtenção do título de Mestre em Agronomia, Área de Concentração: Microbiologia Agrícola.

PIRACICABA

Estado de São Paulo - Brasil

Setembro - 2000 
Dados Internacionais de Catalogação na Publicação (CIP) DIVISÃO DE BIBLIOTECA E DOCUMENTAÇÃO - Campus "Luiz de Oueiroz"/USP

\author{
Lacava, Paulo Teixeira \\ Isolamento, caracterizaçāo genética por RAPD e resistência a antibióticos em Xy/ella \\ fastidiosa / Paulo Teixeira Lacava. - - Piracicaba, 2000. \\ 108 p. : il. \\ Dissertaçāo (mestrado) - - Escola Superior de Agricultura Luiz de Queiroz, 2000. \\ Bibliografia. \\ 1. Bactéria gram-negativa 2. Clorose-variegada-dos-citros 3. Isolamento 4. \\ Marcador genético 5. Resistência ao antibiótico 6 . Variabilidade genética I. Título
}

CDD 589.9

"Permitida a copia total ou parcial deste documento, desde que citada a fonte - $\mathbf{O}$ autor" 
Aos meus Pais,

Pedro M. Lacava e Zilda T. Lacava

pela amor, confiança, estímulos,

dedicação e apoio

\section{DEDICO}

Ao meu irmão e cunhada,

Pedro T. Lacava e Laís M. A. Lacava

pelo amor, amizade e confiança

e

À Karin S. Righetti

pelo amor, carinho, compreensão, paciência e motivação 


\section{AGRADECIMENTOS}

- Ao Departamento de Genética da Escola Superior de Agricultura "Luiz de Queiroz" ESALQ/USP, e em especial ao Prof. Dr. João Lúcio de Azevedo pela orientação, amizade e possibilidade de realização deste trabalho.

- À Profa. Dra. Aline Ap. Pizzirani-Kleiner, pela amizade e facilidades concedidas no Lab. de Genética de Microrganismo - ESALQ/USP.

- Ao Prof. Dr. Pedro M. Lacava pelas discussões e sugestões, além do exemplo como pessoa e profissional.

- Ao Dr. Walter Maccheroni Júnior pela amizade, sugestões, correções e apoio incondicional a este trabalho

- Ao Dr. Welington L. de Araújo pela amizade, sugestões e correções.

- Aos amigos e colegas de laboratório: Ándre Lima, Ágata Giancoli, Cláudia Gai, Carlos Vildoso, Fernando Andreote, Fernando Barcelos, Joelma Marcon, Jucimary Marques, Júlia Sobral, Leonardo de Sousa, Marcelo Gullo, Priscila Rosseto, Ricardo Yara pela ajuda e convivência agradável.

- Ao José Antônio da Silva pelo apoio técnico durante a execução deste trabalho no Lab. de Genética de Microrganismos.

- Aos funcionários do Depto. de Genética da ESALQ/USP, em especial à Adriana, Léia, Neusa, Silvana, Berdã, e Fernando.

- À CAPES pela concessão de bolsa de estudo.

- À FUNDECITRUS pela ajuda na coleta de material e financiamento de parte do trabalho. 


\section{ÍNDICE}

Página

LISTA DE TABELAS _................................................................................. vii

LISTA DE FIGURAS .................................................................................. viii

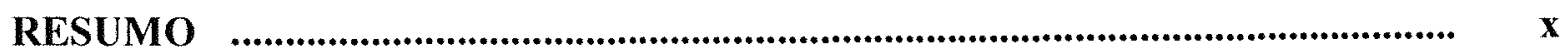

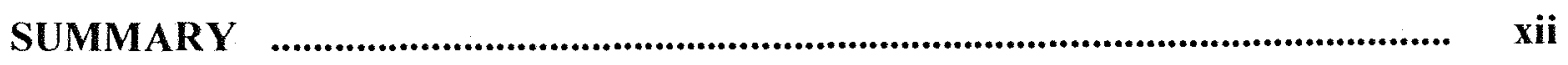

1. INTRODUÇÃO

2. REVISÃO DA LITERATURA ….................................................................

2.1. O Gênero Xylella ......................................................................................... 04

2.1.1. X. fastidiosa e a Clorose Variegada dos Citros (CVC) $\quad$..................................

2.1.2. Sintomas da Clorose Variegada dos Citros (CVC) $\quad$.......................................... 09

2.1.3. Isolamento e cultivo de $X$. fastidiosa

2.1.4. Métodos de Deteç̧ão de $X$. fastidiosa $\quad$................................................................. 12

2.1.5. Variabilidade Genética em $X$. fastidiosa $\quad$...................................................... 14

2.1.6. Seqüenciamento do Fitopatôgeno $X$. fastidiosa .............................................. 17

2.2. Marcadores Moleculares ........................................................................... 18

2.2.1. PCR ("Polymerase Chain Reaction") ........................................................ 18

2.2.2. RAPD ("Random Amplified Polymorphic DNA")

2.2.2.1 Utilização de RAPD em estudos bacteriológicos .......................................... 25

2.3. Resistência à drogas $\quad$................................................................................................ 27

2.3.1. Genética da resistência à drogas $\quad$................................................................. 27

2.4. Modo de ação dos antibióticos .............................................................................. 28

2.5. Antibióticos como Marcas Genéticas ............................................................. 32

2.6. Metodologias para Antibiogramas $\quad$............................................................. $\quad 32$

2.7. Microrganismos endofiticos de citros $\quad$............................................................... 34

3. MATERIAIS E MÉTODOS …................................................................. 36

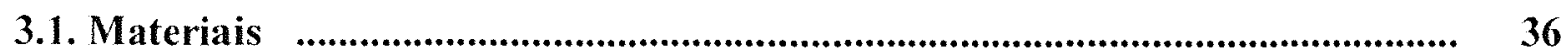


3.1.1. Coleta das amostras vegetais $\quad$.......................................................................... 36

3.1.2. Plantas cítricas empregadas no isolamento _....................................................... 36

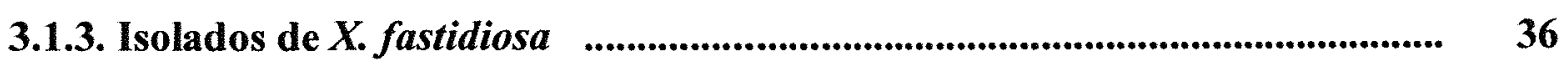

3.1.4. Microrganismos endofíticos de citros $\quad$................................................................... 37

3.2. Meios de Cultura $\quad$................................................................................................................ 37

3.2.1. Meio PW - "Periwinkle Wilt Agar" ............................................................ 37

3.2.2. Meio BCYE ........................................................................................................ 38

3.3. Soluções e Tampões $\quad$............................................................................................. 38

3.3.1. Solução de Glutamina 4 \%

3.3.2. Solução de Soro albumina bovina $10 \%$............................................................. 38

3.3.3. Solução de Hemina clorada $0,1 \%$................................................................ 38

3.3.4. Solução de Vermelho de fenol $0,2 \% \quad$...................................................................... 39

3.3.5. Solução de Hipoclorito de Sódio 1\% ............................................................. 39

3.3.6. Solução Álcool etílico $70 \%$.......................................................................... 39

3.3.7. Solução de cristal violeta

3.3.8. Solução de lugol ..................................................................................... 39

3.3.9. Solução de Safranina $\quad$........................................................................................... 40

3.3.10. Solução de RNase ............................................................................. 40

3.3.11. Solução de fenol saturado

3.3.12. Clorofane ................................................................................................................. 40

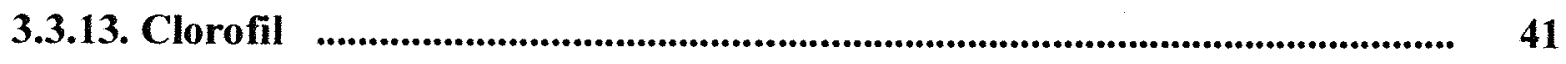

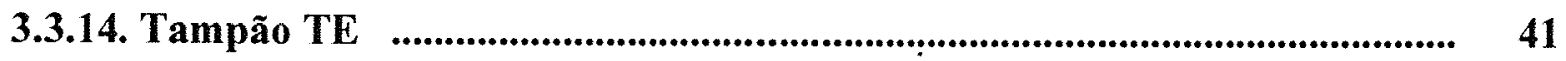

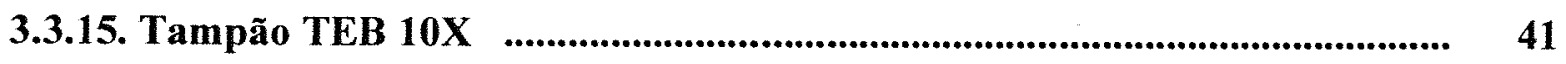

3.3.16. SDS 10\%

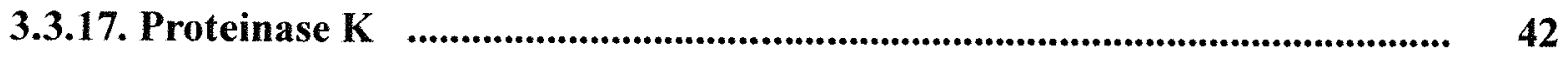

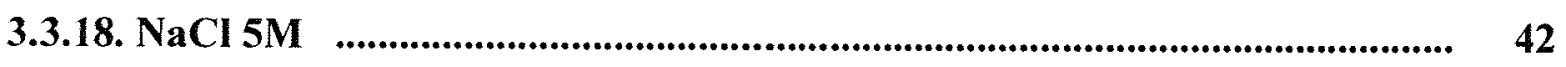

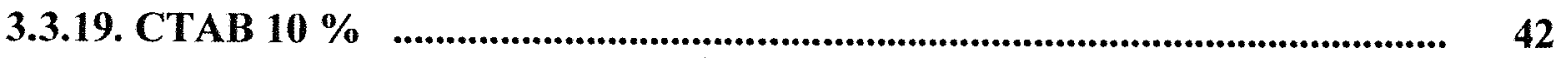

3.3.20.Tampão de amostra $\quad$.................................................................................... 42

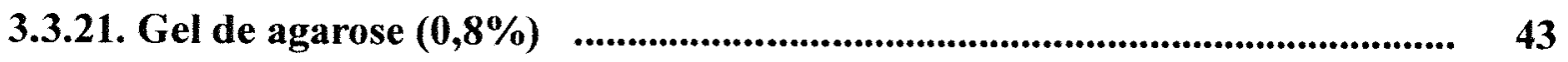

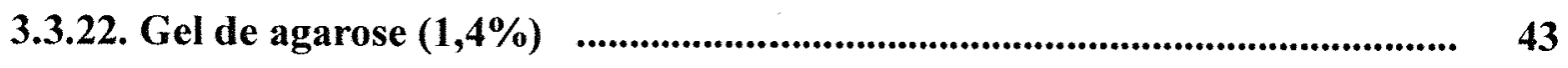


3.3.23. Solução estoque de dNTP's ……..................................................................... 43

3.3.24. Solução estoque de brometo de etídio $(1,0 \%)$............................................... 43

3.3.25. Solução Tris-HCl 1 M ................................................................................... 43

3.3.26. Solução de EDTA 0,5 M (pH 7,5) …………….................................................. 44

3.3.27. Tampão TAE 50X ……....................................................................................... 44

3.4. Marcador de peso molecular ...................................................................... 44

3.4.1. DNA Ladder 100 pb (GIBCO) .......................................................................... 44

3.5. Componentes da Reação de RAPD - PCR ........................................................ 45

3.5.1. "Primers" para deteção da $X$ fastidiosa via PCR ........................................ 45

3.5.2. Tampão de amplificação RAPD-PCR ……….................................................... 45

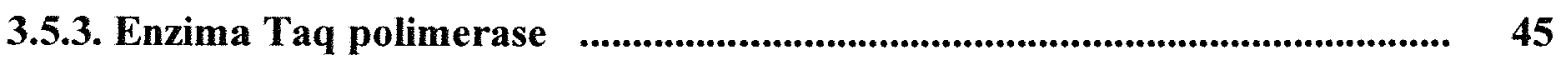

3.5.4. "Primers" para RAPD …..................................................................................... 46

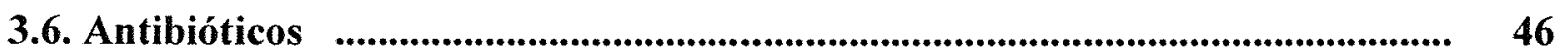

3.6.1. Antibióticos impregnados em disco de papel .................................................. 46

3.6.2. Antibióticos solúveis $\quad$...................................................................................... 47

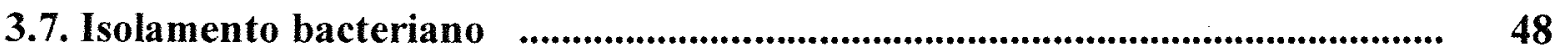

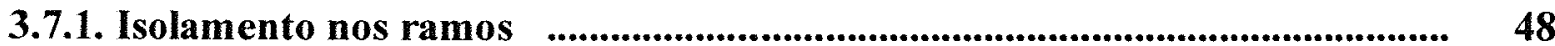

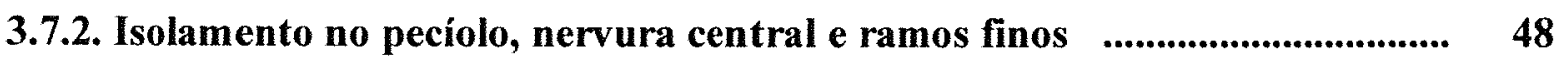

3.8. Identificação dos isolados de $X$. fastidiosa

3.8.1. Características culturais $\quad$.............................................................................. 49

3.8.1.1. Colônia de $X$. fastidiosa

3.8.1.2. Coloração de Gram ........................................................................................ 49

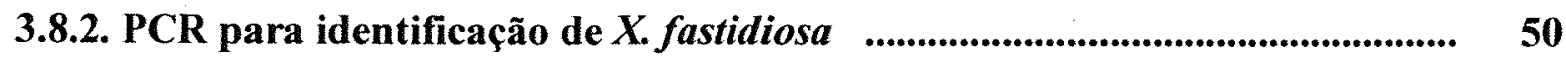

3.9. Extração de DNA genômico total ................................................................ 50

3.10. Análise de polimorfismo gerado por marcadores de RAPD $\quad$........................... 51

3.10.1. Amplificação do DNA genômico .............................................................. 51

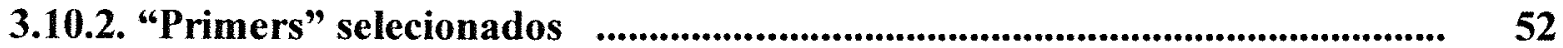

3.10.3. Construção do dendograma $\quad$.......................................................................... 52

3.11. Teste de sensibilidade à antibióticos $\quad$............................................................... 53

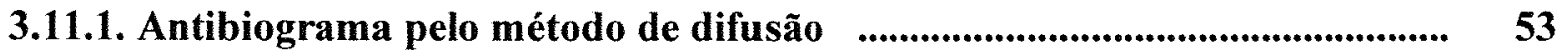


3.11.2. Antibiograma pelo método das diluições em meio líquido $\quad$........................ 53

3.12. Metodologia de interação "in vitro" entre microrganismos endofíticos de citros e $X$. fastidiosa

4. RESULTADOS 55

4.1. Isolamento e cultivo de $X$. fastidiosa de plantas cítricas 55

4.2. Identificação dos isolados de $X$. fastidiosa 56

4.3. Análise de variabilidade genética por RAPD 57

4.3.1. Padronização da técnica de RAPD 57

4.3.2. Escolha dos "primers" 60

4.3.3. Verfificação de polimorfismo por RAPD 60

4.4. Antibiograma pelo método de difusão 62

4.5. Antibiograma pelo método das diluições 63

4.6. Interação “in vitro". entre $X$. fastidiosa e bactérias endofíticas de citros $\ldots . . . \quad 78$

5. DISCUSSÃO 79

6. CONCLUSÕES 86

7. REFERÊNCIAS BIBLIOGRÁFICAS 88 


\section{LISTA DE TABELAS}

Página

Tabela 1 - "Primers" para deteç̧ão de $X$. fastidiosa via PCR …………………….. 45

Tabela 2 - Discos de antibióticos com suas respectivas concentrações $\quad$................. 47

Tabela 3 - Antibióticos e seus respectivos fabricantes e diluentes $\quad$.......................... 47

Tabela 4 - Lista de "primers" selecionados para o RAPD ...................................... 52

Tabela 5 - Isolados de $X$. fastidiosa por hospedeiro e região $\quad$...................................... 56

Tabela 6 - Diâmetro dos halos de inibição (mm) dos isolados de $X$. fastidiosa $\quad \ldots . .64$

Tabela 7 - Concentração mínima inibitória dos antibióticos testados para os 8 isolados de citros, 1 isolados de cafeeiro e 1 isolado de videira.................................. 


\section{LISTA DE FIGURAS}

Figura 1. - Padrão de bandas obtidos no PCR, utilizando os "primers" CVC-1 e 272-2 int., para isolados $X$. fastidiosa obtidos de citros $(1,2,3,4,5,6,7,8,9,10$, $11,12,13,14,15,16,17)$, cafeeiro $(18,19)$ e videira $(20)$

Figura 2. - Padrão de bandas obtidos no PCR, utilizando os "primers" 272-2 e 272-1., para isolados $X$. fastidiosa obtidos de citros $(1,2,3,4,5,6,7,8,9,10,11$, $12,13,14,15,16,17)$, cafeeiro $(18,19)$ e videira $(20)$

Figura 3. - Padrão de bandas obtido para o ajuste da concentração de DNA e $\mathrm{MgCl}_{2}$, utilizando o isolado citros Araraquara e marcador de 100 pb, GibcoBRL, (M), variando a concentração de DNA em 20 ng (a, b, c, d, i, j, l, m) e 50 ng (e, f, g, h, n, o, p, q) e a concentração de $\mathrm{MgCl}_{2} \mathrm{em} 4$ (a, e, i, n), 3 (b, f, j, o), 2 (c, g, l, p) e 1,5 mM (d, h, m, q) utilizando os "primers" OPAX05 (a, b, c, d, e, f, g, h) e OPX06 (i, j, l, m, n, o, p, q)

Figura 4. - Dendograma obtido a partir de uma matriz de similaridade genética entre os isolados de $X$. fastidiosa de citros, cafeeiro e videira. Os números em cada forquilha mostra a porcentagem de vezes, que os agrupamentos à direita ocorreram na análise de "bootstrap"

Figura 5. - Perfil eletroforético obtido com o "primer" OPP06 para os isolados $1(9 \mathrm{a} 5 \mathrm{c}), 2,3,4,5,6,7,8,9,10,11,12,13,14,15,16,20$ para citros, 17, 18 para cafeeiro e 19 para videira

Figura 6. - Presença de halo de inibição de isolado de citros/região Araraquara frente ao antibiótico canamicina após 7 dias de cultivo

Figura 7. - Presença de halo de inibição do isolado 9a5c frente ao antibiótico vancomicina após 20 dias de cultivo

Figura 8. - Presença de halo de inibição do isolado de citros/região Matão frente aos antibióticos polimixina $B$ e neomicina após 30 dias de cultivo 
Figura 9. - Curvas de inibição do isolado de citros da região de Araraquara à diferentes concentrações dos antibióticos

Figura 10. - Curvas de inibição do isolado de citros da região de Matão à diferentes concentrações dos antibióticos

Figura 11. - Curvas de inibição do isolado de citros da região de Macaubal à diferentes concentrações dos antibióticos

Figura 12. - Curvas de inibição do isolado de citros da região de Itapetininga à diferentes concentrações dos antibióticos

Figura 13. - Curvas de inibição do isolado de citros da região de Olimpia à diferentes concentrações dos antibióticos

Figura 14. - Curvas de inibição do isolado de citros da região de Colina à diferentes concentrações dos antibióticos

Figura 15. - Curvas de inibição do isolado de citros da região de Novaes à diferentes concentrações dos antibióticos

Figura 16. - Curvas de inibição do isolado de cafeeiro da região de Marília à diferentes concentrações dos antibióticos

Figura 17. - Curvas de inibição do isolado de videira frente à diferentes concentrações dos antibióticos

Figura 18. - Curvas de inibição do isolado $9 \mathrm{a} 5 \mathrm{c}$ à diferentes concentrações dos antibióticos

Figura 19. - Estímulo de crescimento da X. fastidiosa por Methylobacterium sp. 


\title{
ISOLAMENTO, CARACTERIZAÇÃO GENÉTICA POR RAPD E RESISTÊNCIA A ANTIBIÓTICOS EM Xylella fastidiosa
}

\author{
Autor: Paulo Teixeira Lacava \\ Orientador: Dr. João Lúcio de Azevedo
}

\section{RESUMO}

Xylella fastidiosa é uma bactéria Gram-negativa e fastidiosa, limitada ao xilema das plantas com uma ampla gama de hospedeiros, incluindo mono e dicotilêdoneas, algumas de grande interesse econômico. No Brasil a $X$ fastidiosa é o agente causal da Clorose Variegada dos Citros (CVC), sendo observada nos Estados de São Paulo, Minas Gerais e Paraná. O objetivo deste trabalho foi o isolamento de $X$. fastidiosa de laranja doce (Citrus sinensis), análise molecular da variabilidade genética e resistência a antibióticos. A linhagem 9a5c de $X$. fastidiosa e isolados de cafeeiro e videira foram utilizados como controle nos estudos genéticos e de resistência a antibióticos juntamente com os isolados obtidos neste estudo. A diversidade genética de dezenove isolados foi determinada pela técnica de RAPD. Os resultados mostraram três grupos: o primeiro compreende dezesseis isolados de CVC (incluindo a linhagem 9a5c), o segundo dois isolados de cafeeiro, o terceiro um isolado de videira. Dois subgrupos foram observados no grupo citros, mostrando $72 \%$ de similaridade. A linhagem 9a5c foi incluída em um subgrupo menor, mostrando maior divergência que os outros isolados. Os níveis de resistência aos antibióticos foram avaliados empregando duas técnica: difusão do antibiótico em meio de cultura sólido e diluição em meio líquido. A análise de resistência a antibióticos mostrou que a polimixina B, rifampicina, estreptomicina, canamicina, ampicilina, neomicina, tetraciclina, cloranfenicol e vancomicina o inibiram o crescimento dos isolados estudados, mas esses isolados foram resistentes a penicilina. Estes resultados dão suporte para a hipótese de homogenidade entre isolados causadores da CVC e indicam quais os antibióticos que poderão ser utilizados no desenvolvimento de um 
sistema de transformação para esta bactéria, além de indicar o potencial emprego da antibióticoterapia como uma alternativa a mais de convivência com a CVC. Testes de interação com bactérias endofiticas e $X$. fastidiosa mostraram que Methylobacterium sp. estimulou "in vitro" o crescimento de $X$. fastidiosa. 


\title{
ISOLATION, GENETIC CHARACTERIZATION BY RAPD AND RESISTANCE TO ANTIBIOTICS IN Xylella fastidiosa
}

\author{
Author: Paulo Teixeira Lacava \\ Adviser: Dr. João Lúcio de Azevedo
}

\section{SUMMARY}

Xylella fastidiosa is a Gram-negative bacteria limited to the xylem of the plants with a wide a host range, including mono and dicotiledons, being some of great economic interest. In Brazil, $X$. fastidiosa is the causal agent of Citrus Variegated Chorosis (CVC), which is observed in the State of the State of São Paulo Minas Gerais and Paraná. The objectives of this work were the isolation of $X$. fastidiosa from sweet orange (Citrus sinensis), analyse genetic by RAPD and antibiotic resistance analyses. The reference strains $9 \mathrm{a} 5 \mathrm{c}$ of $X$. fastidiosa and isolates of coffee and grapevine were used as a control in the genetic and antibiotic resistance characterization of isolates obtained in the present study. Diversity of nineteen isolates of $X$. fastidiosa was assessed by RAPD technique. The results showed three groups: the first comprised sixteen CVC isolates (plus 9a5c strain), the second two coffee isolates, third one citrus isolate and the forth one grapevine isolate. Two subgroups were observed in the citrus group showing $72 \%$ similarity. Strain 9a5c was incluted in the small subgroup and showed more divergence than other isolates. The level of antibiotics resistance was evaluated by two techniques: diffusion of antibiotic laid over solid culture medium and dilution in liquid medium. The antibiotic resistance analysis showed that polymixin B, rifampcin, streptomycin, kanamycin, ampicillin, neomycin, tetracycline, chloramphenicol and vancomycin inhibited the growth of the studied isolates, but these isolates were penicillin resistant. These findings support the idea of genetic homogeneity among isolates of $X$. fastidiosa causing CVC, and indicate antibiotics that might be useful in the development of transformation systems for this bacteria, and indicate the potential employment of 


\section{INTRODUÇÃO}

A Xylella fastidiosa é uma bactéria Gram-negativa, limitada ao xilema das plantas, com crescimento fastidioso em meios de cultura, sendo fitopatogênico para uma ampla gama de hospedeiros incluindo plantas mono e dicotiledôneas.

Esta bactéria é responsável por causar doenças em culturas de grande importância econômica como o Mal de Pierce em videira (PD), Escaldadura da folha da ameixeira (EFA), Clorose Variegada dos Citros (CVC) e Escaldadura da folha do cafeeiro (CLS).

A transmissão deste patógeno ocorre por meio de enxerto contaminado e por cigarrinhas sugadoras de seiva do xilema.

A Clorose Variegada dos Citros (CVC), caracteriza-se como uma doença destrutiva que limita a produção de cítricos em diversas áreas no Brasil. Esta doença foi observada pela primeira vez nos Estados de São Paulo e Minas Gerais em 1987 (Lee et al., 1993).

O patógeno coloniza os vasos de xilema da planta hospedeira, causando redução na produção e qualidade dos frutos, sendo a doença de grande importância econômica para a citricultura brasileira, que hoje representa cerca de $30 \%$ da produção mundial da fruta.

A doença afeta todas as variedades comerciais de laranja doce, independente do porta-enxerto. Os sintomas da CVC são observados desde plantas em viveiro até em pomares adultos. Em árvores com mais de 15 anos, estes sintomas são mais localizados, e raramente a árvore toda é afetada. 
Os métodos atualmente descritos para o isolamento de $X$. fastidiosa são de baixa eficiência e apresentam elevado índice de contaminação, existindo poucas informações sobre a eficiência dos meios de cultura para a linhagem causadora da CVC.

Atualmente, todas as linhagens do gênero Xylella são classificados em uma única espécie. Entretanto, há diferenças em relação aos hospedeiros, requerimentos nutricionais e patogenicidade.

A $X$. fastidiosa foi o primeiro fitopatógeno a ser seqüenciado, devido a importância econômica da citricultura e da CVC, tamanho do genoma, além do conhecimento da biologia desta bactéria e possibilidade de manipulação genética, afim de buscar subsídios para um possível controle da CVC.

Poucas informações existem sobre o comportamento de $X$. fastidiosa frente à antibióticos, havendo desta forma, a necessidade de informações qualitativas e quantitativas desta sensibilidade.

O conhecimento da sensibilidade da $X$. fastidiosa em relação aos antibióticos são informações importantes que deverão auxiliar no desenvolvimento de um sistema de transformação. Especialmente após o seqüenciamento total de seu genoma, pois uma das formas mais comum do estudo de genes envolvidos com patogenicidade é por inativação gênica, passando necessariamente pela transformação desta bactéria.

Dentro deste contexto o presente trabalho tem como objetivo:

$\rightarrow$ Comparar duas metodologias propostas de isolamento de $X$ fastidiosa.

$\rightarrow$ Isolamento e análise de variabilidade genética por RAPD de isolados de plantas cítricas afetadas pela CVC originários de diferentes regiões do Estado de São Paulo e de isolados do cafeeiro, videira e do isolado referência 9a $5 \mathrm{c}$ de $X$. fastidiosa de citros.

$\rightarrow$ Utilizar os métodos de difusão e de diluição de antibióticos para a avaliação qualitativa e quantitativa da sensibilidade da $X$. fastidiosa aos mesmos.

$\rightarrow$ Determinação da concentração mínima inibitória de antibióticos frente aos isolados de $X$ fastidiosa obtidos das diferentes regiões do Estado de São Paulo. 
$\rightarrow$ Teste de interação "in vitro" de $X$. fastidiosa com microrganismos endofiticos de citros para verificar possível antagonismo. 


\section{REVISÃO DA LITERATURA}

\subsection{O Gênero Xylella}

Nos últimos 100 anos, algumas frutíferas de importância econômica, principalmente na América do Norte, passaram a sofrer grandes perdas em função de doenças causadas pela bactéria Xylella fastidiosa. Os dados observados inicialmente foram atribuídos, a algum tipo de microrganismo capaz de se manter viável durante o processo de propagação vegetativa das mesmas (Hewitt, 1939). Relatos sobre vírus (Cochran \& Hurtchins, 1976) e bactérias da família Rickettsiaceae (Goheen et al., 1973; Hopkins \& Mollenhaver, 1973) sucederam-se, respectivamente, como possíveis agentes causais destas doenças. No final da década de 70, Davis et al. (1978) reportaram o isolamento e cultivo de uma bactéria limitada ao xilema ('Xylem limited bacterium XLB') de videiras (Vitis vinífera L.) afetadas pelo Mal de Pierce ('Pierce's disease') na Califórnia (EUA). Posteriormente, Raju et al.(1982) e Wells et al. (1983) também isolaram e cultivaram os agentes causais da escaldadura da ameixeira (Prumus persica (L.) Barsch) ('Phony Peach') na Geórgia (EUA), respectivamente.

A $X$. fastidiosa é um a bactéria Gram-negativa, restrita aos vasos do xilema de seus hospedeiros e disseminada através de vetores, que são cigarrinhas sugadoras da seiva do xilema, pertencentes às famílias Cicadellidae (Subfamília Cicadellinae) e Cercopidae (Purcell \& Finlay, 1979 e Purcell \& Hopkins, 1996). Esta bactéria sobrevive em dois ambientes, no xilema e no lúmen do canal alimentar anterior dos insetos hospedeiros. Baixa concentração de nutrientes disponíveis, alta turbulência e pressão são características dos vasos do xilema e do canal alimentar das cigarrinhas vetores (Raven, 
1984). Assim, acredita-se que a adesão da bactéria à planta ou inseto, seja vital para sua existência e desenvolvimento segundo (Davis, et al., 1981b e Hopkins, 1989) .Na década de 80 , verificou-se que as bactérias estudadas até então não pertenciam à família Rickettsiaceae, propondo-se inicialmente, o nome de Xylemella fastidiosum para o agente causal do Mal de Pierce ('Pierce's disease') (Wells et al., 1987). Logo em seguida o nome Xylella fastidiosa passou a ser utilizado em um estudo comparativo com linhagens de diferentes hospedeiros por Wells et al. (1987) e uma extensa revisão sobre o gênero Xylella foi feita por Hopkins (1989). Estudos iniciais desenvolvidos por Kamper et al., (1985) revelaram o conteúdo Guanina + Citosina de Xylella fastidiosa variando de 50,1 a 54,0 moles \%, enquanto que para Rochalimaea quintana (Rickettsiae) aqueles valores estão ao redor de 38,5 moles \%. Esta diferença demonstrou claramente que 'XLB' e Rickettisiae pertenceriam a espécies diferentes.

Weels et al. (1987), em um extenso estudo envolvendo bioquímica, sorologia, enzimologia, análise de ácidos graxos, DNA e RNA, de vinte e cinco linhagens de bactérias limitada ao xilema, incluindo isolados de videira, pessegueiro, vinca (Catharantus roseus (L.) G. Don), amendoeira, ameixeira, elmo (Ulmus americana L.) e 'maple' (Acerrubrum L.), concluíram que as linhagens pesquisadas formavam um grupo homogêneo, embora diferenças tenham sido verificadas principalmente quanto a taxa de crescimento entre as linhagens em meio de cultura definido. Os resultados dos estudos de hibridização de DNA e seqüências de 16S rRNA confirmaram que as bactérias limitadas ao xilema como uma espécie única, associada ao subgrupo gamma das eubactérias, excluindo deste modo qualquer relação com Rickettsiae. Em razão destes estudos, Wells et al. (1987) propuseram a criação de um novo gênero, Xylella, com a espécie Xylella fastidiosa sp Nov..

Recentemente, Purcell \& Hopkins (1996) definiram as bactérias limitadas ao xilema como bactérias endofiticas parasitas; $X$. fastidiosa e outras, que habitam exclusivamente os elementos de vasos ou traquídeos constituintes do xilema da planta hospedeira. 
Wells et al., (1987) propõem para a $X$. fastidiosa e outras bactérias habitantes exclusivamente do xilema de plantas hospedeiras as seguintes características: "Células em bastonetes, medindo 0.25-0.35 x 0.9-3.5 $\mu \mathrm{m}$, Gram-negativas, não móveis, aflageladas, oxidase negativa e catalase positiva, aeróbia estritas, não fermentativas, não halofilicas e não pigmentadas, nutricionalmente fastidiosas, temperatura ótima para crescimento ao redor de $26-28{ }^{\circ} \mathrm{C}$, pH ótimo $6,5-6,9$, hidrolizam gelatina, utilizam piruvato, não fermentam glucose, sendo negativa para indol, $\mathrm{H}_{2} \mathrm{~S}$, lipase, amilase, fosfatase, $\beta$ galactosidas, com conteúdo $\mathrm{G}+\mathrm{C}$ entre 51.0 a 52.4 moles \%. A linhagem tipo é ATCC $35879^{\prime \prime}$.

Miranda (1998), avaliando a atividade bioquímica em $X$. fastidiosa, isolada de citros, obteve resultados positivos para as seguintes provas bioquímicas: catalase, amilase, p-n-p-acetilglucosamina, prolina-nitroanilida, Y-1-glutamil, p-nitroanilida, inositol, p-n-p-fosfato, dextrose e celobiose.

Atualmente, $X$. fastidiosa é considerada membro da subdivisão gamma, ordem Lysobacteriales, família Lysobacteriacea, grupo Xanthomonas, gênero Xylella, com uma única espécie.

A primeira doença causada por $X$ fastidiosa a ser relatada foi a de Pierce ('Pierce's Disease - PD) em videira na California, EUA, no final do século XIX (Pierce, 1982). Durante oitenta anos acreditou-se que o patógeno era de origem viral, por suas características de transmissão, uma vez que é transmitido por enxertia e insetos vetores, além dos sintomas de necrose marginal em folhas (Winkler, 1949). Posteriormente, a bactéria foi visualizada através de microscopia nos vasos do xilema de plantas sintomáticas (Hopkins \& Mollenhauer, 1973). A partir do primeiro isolamento dessa bactéria em meio de cultura (Davis et al., 1978), outras doenças foram diagnosticadas tendo a $X$. fastidiosa como agente causal (Purcell, 1997).

Purcell (1997) listou plantas cultivadas para as quais a $X$. fastidiosa é patogênica, sendo a maioria dos hospedeiros espécies arbóreas e perenes, como citros, videira, ameixeira, cafeeiro e carvalho. Entre culturas herbáceas, são relatadas vinca (Catharantuns roseus) e apenas uma espécie anual de alfafa. Provavelmente, habitar 
espécies perenes e ser limitada ao xilema confere maiores chances ao patógeno de manter-se no ambiente em períodos desfavoráveis, como no inverno ou entresafra.

Inicialmente encontrada apenas no continente americano, relatos de sua presença na Ásia (Leu \& Su, 1993) e Europa (Berisha et al., 1998) demonstraram uma distribuição mais global da bactéria.

\subsubsection{Xylella fastidiosa e a Clorose Variegada dos Citros (CVC)}

A bactéria $X$. fastidiosa foi encontrada em vasos do xilema de plantas cítricas doentes, considerada o agente causal da Clorose Variegada dos Citros (CVC). A doença foi constada pela primeira vez no Brasil em 1987, em pomares de Colina - SP, em seguida no Triângulo Mineiro e nas regiões Norte e Nordeste do Estado de São Paulo (De Negri, 1990; Lee et al., 1992; Chang et al., 1993; Hartung et al., 1994).

A Clorose Variegada dos Citros (CVC), causada pela bactéria X. fastidiosa é uma nova doença que, no Brasil, com caráter destrutivo limita a produção de cítricos. A doença recebeu o nome vulgar de "amarelinho", devido ao aspecto amarelado, na parte superior, das plantas afetadas e nos frutos miúdos, precocemente amadurecidos. Denomina-se Clorose Variegada dos Citros ou CVC, devido às características foliares da planta (Rossetti \& De Negri 1990).

Carvalho (1994), constatou que a CVC ataca todas as variedades comerciais de laranja doce (Pêra, Natal, Hamlin, Valência, Folha Murcha, Baianinha e Barão) sobre

diferentes porta-enxertos (Limão Cravo, Trifoliata, Tangerinas Cleópatra e Sunki, Laranja Caipira e etc). Entretanto, não foi encontrado sintomas nas tangerinas comerciais (Cravo e Poncan), Tangor Murcote, limões verdadeiros (Siciliano e Eureca) e Lima Ácida Galego, mesmo quando as plantas estão localizadas em áreas altamente infectadas.

Pelas observações de campo, verificou-se que a doença é mais severa quando atinge plantas jovens, diminuindo quando as árvores atingem 8-10 anos após o plantio. Assim, é preciso que medidas sejam tomadas visando permitir que as plantas afetadas possam ultrapassar essa fase crítica (De Negri, 1990). 
Após a primeira constatação no Brasil (Colina, SP), em 1987, a doença foi constatada em 1988 (Macaubal, SP), onde se observou um ataque extremamente severo. Em 1989 disseminou-se rapidamente por outras regiões do Estado de São Paulo: Tanabi, São José do Rio Preto, Mirassol, Cedral, Barretos, Bebedouro, Jaborandi, Matão, além do Triângulo Mineiro e Alfenas, em Minas Gerais (1989), alcançando a fronteira do Mato Grosso do Sul e Arredores de Campinas. (Tubelis et al., 1992). Foi constatada a doença também no Rio de Janeiro (Lee et al., 1991), Goiás (Tubelis, 1993), Paraná (Leite et al., 1993), e na região da Zona da Mata de Minas Gerais (Mizubuti et al., 1994). Mais tarde, foi constatada em Sergipe, Santa Catarina, Distrito Federal e Rio Grande do Sul (Tubelis et al., 1993).

A bactéria no interior da planta está sempre associada a uma matriz gelatinosa e juntas reduzem o lúmem das células do xilema e como conseqüência à dinâmica da água dentro da planta fica bastante prejudicada, afetando processos fisiológicos vitais, como a fotossítese, respiração e distribuição de nutrientes (Rossetti et al., 1990; Machado et al., 1994).

Segundo Rossetti \& De Negri (1990) a CVC declina a qualidade dos frutos, tornando-os de tamanho reduzido, imprestáveis para a comercialização "in natura" e produção de suco cítrico concentrado, pois os frutos são menores, rígidos e com sabor mais ácido (Menegucci et al., 1995).

É provável que a estirpe de $X$. fastidiosa causadora da Clorose Variegada dos Citros no Brasil seja originária de ervas daninhas ou de outras culturas e levada para a laranjeira por vetores da ordem Homoptera (Hartung, et al.,1994). Esses vetores são as cigarrinhas sugadoras do xilema destas plantas. As espécies Dilobopterus costalimai, Acrogonia sp e Oncometopia facialis, transmitem a bactéria, para plantas cítricas sadias, após sua alimentação em plantas infectadas (Lopes et al., 1996; Roberto et al., 1996).

A cigarrinha adulta contaminada, inocula a $X$. fastidiosa, nas plantas cítricas, durante todo o seu ciclo de vida (Purcell, 1997). A bactéria sobrevive no aparelho bucal das cigarrinhas transmissoras e nos vasos do xilema da planta, fechando o ciclo infectante, após sua alimentação (Donadio et al., 1997). 
No Brasil Leite Jr. \& Leite (1991) foram os primeiros a cultivá-la. Lee et al. (1992) também relatam o cultivo da bactéria. O postulado de Koch foi inicialmente fechado na França e reportado por Chang. et al., (1993), e posteriormente nos Estados Unidos por Lee et al. (1993) e por Hartung et al. (1994), confirmando que a CVC é causada pela bactéria $X$. fastidiosa.

\subsubsection{Sintomas da Clorose Variegada dos Citros}

Os sintomas genéricos causados pela bactéria $X$. fastidiosa podem ser normalmente agrupado em dois tipos: queimadura de limbo foliar com seca total ou parcial da planta afetada e redução de porte da copa. (Purcell \& Hopkins, 1996; Lima et al., 1996). Em citros os sintomas podem ser resumidos em a) clorose das folhas inicialmente na parte mediana e superior da copa, tomando depois toda a planta b) folhas com sintomas de deficiência nutricional, normalmente de zinco, boro e carência de potássio (frutos miúdos); c) manchas cloróticas da face ventral, correspondendo a pequenas bolhas de goma de cor palha na face dorsal, semelhante a manchas devido a toxicidade de boro (Donadio et al., 1997). A análise foliar, entretanto, mostrou que não ocorre nível de boro próximo a toxicidade (Quaggio, 1988).

Agrious (1997) em estudos constatou que os sintomas da doença surgem com o aumento do agregado bacteriano no xilema, esse agregado acompanhado de tiloses e gomas produzidas pela planta entopem os elementos vasculares do vegetal, restringindo a condução da água para os tecidos da planta, a bactéria também produz uma fitotoxina que pode contribuir para o desenvolvimento dos sintomas.

\subsubsection{Isolamento e Cultivo de $X$. fastidiosa}

$\mathrm{O}$ agente causal do Mal de Pierce foi somente isolado e cultivado artificialmente na década de 70 por Davis et al. (1978). Esta bactéria foi primeiramente associada ao Mal de Pierce da videira, doença que ocorre nos Estados Unidos, México e Costa Rica, e que 
durante várias décadas foi atribuída a vírus. Cochran \& Hutchins (1976). Goheen et al., (1973) e Hopkins \& Mollehauer (1973) estudando etiologia da doença por meio de quimioterapia, termoterapia e microscopia eletrônica concluíram que esta moléstia era causada por uma bactéria do tipo rickettsia ('Rickettsia-like'), em razão da morfologia e da possibilidade do seu cultivo em meios artificiais.

Posteriormente, Davis et al., (1978) utilizando meio de cultura (denominado PD) derivado de meio originalmente desenvolvido para isolamento de espécies de Rochalimaea e do gênero Legionela, conseguiram o isolamento primário da bactéria agente causal do Mal de Pierce de plantas de videiras, como XLB ou FXLB ('fastidious xylem-limited bactéria'). Este fato tornou possível a realização de pesquisas relacionadas à taxonomia, patogenicidade e epidemiologia desta bactéria. Naquela época este microrganismo já era visualizado em microscopia eletrônica e associado à doença (Hopkins \& Mollenhaver, 1973).

Mais tarde, Davis et al., (1981a) estabeleceram o cultivo deste mesmo microrganismo a partir de ramos com sintomas de escaldadura na ameixeira e de pecíolos de plantas com redução de porte em pessegueiro ('Phony Peach').

A partir do primeiro relato do cultivo da bactéria em meio de cultura PD outros meios foram desenvolvidos tais como PD2 (Davis et al., 1978), PW (Davis et al., 1981a), PWH (Lee et al., 1993), SPW (Hartung et al., 1994) e PWG (Hill \& Purcell, 1995a). Apenas pequenas modificações relacionadas à composição, quantidade de reagentes e troca de gelificantes foram realizadas em relação ao meio original. O meio BCYE (Wells et al., 1981), apesar de possuir composição diferente, possui fontes alternativas de nutrientes dos demais meios. Posteriormente, o meio CS20 foi desenvolvido, tendo vantagem sobre os demais por ser totalmente autoclavável (Chang \& Walker, 1988).

Chang \& Donaldson (1993) isolaram X. fastidiosa em meio quimicamente definido, mantendo crescimento e periodo de incubação semelhantes aos meios PD2 e CS20. O conhecimento da composição do meio de cultura pode auxiliar estudos sobre as necessidades nutricionais da bactéria, possibilitando melhor compreensão de seu metabolismo. Chang et al. (1990) obtiveram crescimento bacteriano em ágar nutriente 
para uma estirpe de PD. Uchibaba et al. (1992) compararam crescimento de estripe de ameixeira em ágar nutriente e outros meios, observando para o primeiro eficiência de isolamento inferior ao BCYE.

Aparentemente, alguns reagentes presentes nos meios utilizados para $X$. fastidiosa, tais como soro albumina bovina, carvão ativado e amido de batata, favorecem o crescimento bacteriano mas não são essenciais (Davis et al., 1978), agindo possivelmente na desintoxicação do meio, seqüestrando compostos inibidores provenientes do meio ou do tecido do hospedeiro durante isolamentos primários (Davis et al., 1978; Wells et al., 1981; Chang \& Donaldson, 1993). Fontes de ferro, tais como pirofosfato férrico e cloreto de hemina, também presentes nos meios, não são essenciais à bactéria, mas estimulam seu crescimento (Chang \& Donaldson, 1993).

Poucas informações existem sobre a eficiência dos meios específicos para a estirpe causadora da CVC. O primeiro isolamento de citros no Brasil foi realizado por Leite Jr. \& Leite (1991), utilizando o meio BCYE, contudo informações sobre sua performance não foram relatadas. Para fechamento dos postulados de Koch, foram utilizados os meios PW e PWH (Chang et al., 1993 e Lee et al., 1993), observando-se, grande variação no período de incubação para surgimento de colônias ( 9 a 20 dias). Posteriormente, Hartung et al. (1994) desenvolveram o meio PWS suplementado por fatores de crescimento e adicionado de extratos de tecido cítrico. Comprado com PD2, mostrou-se superior; onde diâmetros das colônias após 21 dias atingiam 0,35-0,36 mm, embora tenha sido inferior para algumas estirpes de $X$. fastidiosa testadas. Entretanto em 2000, comunicação pessoal Hartung, enfatizou que o meio PW é o que melhor se adequa ao crescimento de $X$. fastidiosa.

Material com sintomas da doença foram coletados no Norte do Estado de São Paulo, e usados para o isolamento. Os meios de cultura usados inicialmente foram o 'Pierce disease agar-PD3' (Davis et al. 1978), 'periwinkle wilt agar PW' e o meio 'PWH', que é o meio PW suplementado com L-histidina.

Em geral, os métodos atualmente usados para isolamento de $X$. fastidiosa de citros são de baixa eficiência, apresentando elevados índices de contaminação e não 
permitindo a quantificação da população bacteriana no tecido vegetal amostrado. A quantificação em meio de cultura pode ser realizada através da contagem de unidades formadoras de colônias (UFC) em suspensão, com peso de tecido e volume de tampão conhecido. Hopkins (1985) quantificou $X$. fastidiosa em videira, macerando pecíolos sintomáticos (previamente esterilizados superficialmente), filtrando a suspensão obtida em gaze, centrifugando para concentrar o número de bactérias, ressuspendendo o concentrado e semeando em meio sólido. Através de método semelhante.

Fry \& Milholland (1990) estudaram a multiplicação e translocação da bactéria em variedades de videira. Apesar de ambos os métodos quantificarem a bactéria, os procedimentos são trabalhosos e sujeitos a desuniformidade no processamento de cada amostra. Além disso, a sensibilidade desses métodos é cerca de 100-1000 vezes menor que a de outro método posteriormente descrito por Hill \& Purcell (1995). Com esterilização superficial, picagem e homogenização de tecidos em macerador elétrico, e posterior plaquamento da suspensão resultante, Hill \& Purcell (1995) conseguiram detectar populações de $10^{9} \mathrm{UFC} / \mathrm{g}$ de $X$. fastidiosa em videira, com uma sensibilidade teórica de $10^{3}$ células por grama de tecido amostrado.

Almeida (1999), em estudo comparativo de meios de cultura para isolamento de X. fastidiosa, adaptou a metodologia descrita por Hill \& Purcell (1995) para o isolamento em tecido cítrico utilizando os seguintes meios de cultura: PW, PWG, BCYE, concluindo que os três meios de cultura testados promoveram crescimento bacteriano, porém com diferenças na eficiência de isolamento, diâmetro de colônias e período de incubação. $\mathrm{O}$ meio BCYE promoveu crescimento mais lento, colônias menores e menor eficiência de isolamento do que o PW e PWG. Os meios PW e PWG, que são quimicamente similares, mostraram resultados semelhantes.

\subsubsection{Métodos de Deteç̧ão de $X$. fastidiosa}

Os métodos de diagnóstico são ferramentas importantes na identificação do patógeno, nos estudos de transmissão da doença, na relação patógeno-planta, e no 
manejo da doença. Desde o início do estudo da relação da CVC com a bactéria $X$. fastidiosa, estas metodologias foram fundamentais para a consolidação do agente causal da doença.

A microscopia eletrônica de transmissão foi de grande importância nas primeiras detecções da $X$. fastidiosa em plantas cítricas com sintomas (Rossetti \& De Negri, 1990; Chagas et al., 1992). Lima et al. (1995) consideram a sensibilidade do microscópio óptico adequado à deteç̧ão de $X$. fastidiosa. Os teste imunoenzimáticos mais usados para detecção são ELISA ('Enzyme Linked Immunosorbent Assay'), o DIBA ('Dot Immunobinding Assay') e o 'Western Blot'.

O DIBA ('Dot Immuno-binding Assay') tem sido utilizado amplamente por sua praticidade e economia. Inicialmente foram empregadas em tais testes os antisoro UF-26, produzido na Flórida e o produzido na França. Ambos utilizaram como antígenos à bactéria $X$. fastidiosa isolada de plantas cítricas com sintomas de CVC do Brasil (Lee et al., 1992; Garnier et al., 1993). Atualmente o antisoro obtido por Harakava \& Beretta (1994) também esta disponíveis.

Testes moleculares para detecção da $X$. fastidiosa foram inicialmente utilizados por Minsavage et al. (1994), Pooler \& Hartung (1995a), e Beretta et al. (1997). A técnica utilizada para estes testes é a de PCR ('Polymerase Chain Reaction) (Sambrook et al., 1989).

Em experimentos preliminares a técnica de PCR com "primers" específicos para $X$. fastidiosa, desenvolvidos por Minsavage et al. (1994), foi possível detectar a bactéria em folhas com sintomas de CVC. Avaliação da sensibilidade do PCR mostrou que é possível a detecção da bactéria em concentrações inferiores às verificadas com testes imunoenzimáticos (Beretta et al., 1997). A técnica de PCR empregada mostrou-se portanto mais sensível sendo uma ferramenta importante para a deteç̧ão de $X$. fastidiosa. Pode ser utilizada em plantas cítricas, em cigarrinhas e em possíveis plantas hospedeiras alternativas. Entretanto, o controle das condições gerais do laboratório deve ser rigoroso pois o risco de contaminação ou de inconfiabilidade nos resultados deve ser considerado. 
Apesar de se mostrarem apropriados para diagnósticos da CVC, os "primers" desenvolvidos por Minsavage et al. (1994), não possuem a capacidade de diferenciar estirpes de $X$. fastidiosa. Pooler \& Hartung (1995a) desenvolveram "primers" específicos para a deteç̧ão de $X$. fastidiosa da CVC, partindo de produtos obtidos de RAPD (Random Amplified Polimorphic DNA). Estes "primers" também reconhecem $X$. fastidiosa de cafeeiros (Lima et al., 1998).

Beretta et al. (1997) desenvolveram "primers" especificos para estirpe de $X$. fastidiosa da CVC, com base na seqüência derivada dos "primers" da região consensual do tRNA. A construção destes "primers" específicos foi produto de estudos de diversidade da bactéria e estes podem assumir importância na detecção de determinadas estirpes.

Todas estas tecnologias podem ser úteis no diagnóstico de tecidos com sintomas atípicos ou tecidos assintomáticos, especialmente em pesquisa científica. Entretanto uma simples e criteriosa avaliação visual dos sintomas, na maioria dos casos, pode diagnosticar doenças causadas pela bactéria $X$. fastidiosa.

\subsubsection{Variabilidade Genética em $X$. fastidiosa}

Pooler \& Hartung (1995b) com base em RAPD, analisaram a relação genética entre 11 linhagens de $X$. fastidiosa isoladas de ameixeira, amendoeira, citros, elmo e videira, e concluiram ser possível à existência de cinco grupos de Xylella: citros, ameixeira - elmo, videira - ambrosia sp., amendoeira e amoreira. Rosato et al. (1998) analisaram a diversidade de uma população de $X$. fastidiosa isoladas de plantas cítricas com sintomas de CVC pela técnica de RAPD. Foi amplificado por PCR um fragmento de $1,2 \mathrm{~kb}$ de uma sequiência espaçadora de rDNA da região 16-23S seguida por digestão com enzimas de restrição. Os resultados sugerem uma baixa variabilidade entre os isolados de $X$. fastidiosa oriundas de plantas cítricas.

Uma grande variabilidade fisiológica entre estirpes tem sido evidenciada por diferenças observadas no tempo de surgimento de colônias em meio de cultura; este 
período de incubação tem variado de 6 dias para estirpes de videira (Davis et al., 1978), 9 dias para estirpes de citros (Chang et al., 1993).

Apesar de ser considerada uma espécie homogênea, sabe-se que a $X$. fastidiosa é bastante variável, principalmente quanto a sua faixa de hospedeiro, onde são distinguidos vários grupos. Hopkins (1989) relata que plantas de 28 familias incluindo mono e dicotiledôneas seriam hospedeiras de linhagens de PD. Outro grupo seria formado por linhagens oriundas de pessegueiro, incluindo também isolados de Prunus spp. e outros.

Diferenças entre linhagens de $X$. fastidiosa oriunda de diferentes hospedeiros, foram notadas inicialmente quanto ao seu crescimento em diversos meios de cultura. Deste modo, 2 grupos foram distinguidos para $X$. fastidiosa, ou seja, linhagens isoladas de videira e elmo (grupo Pierce's) crescem no meio PD3, PW e BCYE, enquanto que linhagens de pessegueiro, ameixeira e vinca não crescem em meio PD3. Fry et al. (1992) observaram também diferenças na produção de proteases entre linhagens de $X$. fastidiosa oriundas de videira.

Chen et al. (1992a) estudando linhagens de X. fastidiosa de diferentes hospedeiros, verificaram por meio de enzimas de restrição EcoRI, Hinfl, Mspl e TaqI, a presença de 3 plasmídios em linhagens, oriundas de vinca, videira e amoreira. Chen et al (1992b) utilizando RFLP ('Restriction Fragment Length Polymorphism'), analisaram 24 linhagens de $X$. fastidiosa, isoladas de 8 diferentes hospedeiros. Sondas obtidas com a linhagem R112V2 (videira) por meio de hibridização revelaram que as 16 linhagens de videiras estudadas são extremamente uniformes (coeficiente de similaridade entre 0.61 0.69 ), e a ainda, 2 linhagens provenientes de amoreira estariam incluídas neste grupo, o mesmo ocorrendo com um isolado de Ambrosia sp.

Pooler et al. (1997) seqüenciaram um plasmídio de X. fastidiosa com 1296 nucleotídeos, sendo que de 19 isolados de $X$. fastidiosa, apenas 2 isolados continham o plasmídio denominado pXF868, sendo um isolado de amoreira (ATCC 35868) e outro de videira (ATCC35878). Para determinar a presença deste plasmídio nos demais isolados, utilizou-se a análise de Southern Blot, sendo detectado somente no isolado ATCC 35878 a presença desse plasmídio. 
Minsavage et al. (1994) em estudos para desenvolvimento de sonda específica para deteç̧ão de $X$. fastidiosa, e utilizando fragmento ao redor de 7.4- kb do DNA genômico de linhagens do grupo PD, verificaram também que amplificação por PCR possibilitou a diferenciação de pelo menos 2 patotipos de $X$. fastidiosa: o grupo PD e o grupo 'Phony peach'.

Chen et al. (1995), utilizando 14 "primers" em RAPD aplicados em 17 linhagens de $X$. fastidiosa, sendo 7 obtidos de videira, 7 de carvalho, 2 de ameixeira e 1 de vinca confirmaram alta similaridade entre as 7 linhagens do grupo PD, bem como entre as linhagens de carvalho sugerindo a existência de um novo grupo.

Rodrigues Neto et al. (1992), analisando duas linhagens de X. fastidiosa isoladas de citros por meio de eletroforese de proteínas totais, em comparação com linhagens de videira, Ambrosia sp., plátano e ameixeira, verificaram similaridade entre os perfis obtidos.

Beretta et al. (1992), em experimentos serológicos utilizando antisoro produzido contra linhagens de $X$. fastidiosa isoladas de citros (CVC), em testes DIBA para detecção da bactéria em tecidos, observaram que antisoro preparado para a CVC reagiu também fortemente com linhagem de pessegueiro, e em menor intensidade com linhagem do grupo PD. A similaridade entre as doenças CVC e 'pecosita' também foi verificada por Brlansky et al. (1993) por imunofluorescência.

Leite et al. (1993), analisaram por meio de hibridização por "Southern Blot" de DNA fragmentos de várias linhagens de $X$. fastidiosa, incluindo videira, ameixeira, carvalho, plátano e erva-lanceta e, uma linhagem encontrada em plantas com 'Blight' dos citros dos EUA (com patogenicidade não confirmada). Este estudo revelou que sonda de DNA plasmidial de videira reagiu apenas com linhagem homóloga.

Hartung et al (1994), utilizando o DAS-ELISA ('double antibody sandwichELISA') verificaram relacionamento serológico entre linhagens de CVC e PD, entretanto, observaram também forte reação com outras linhagens, sugerindo que a CVC poderia pertencer a um grupo intermediário. 
Pooler \& Hartung (1995a) através de clonagem e seqüenciamento com amplificação, distinguiram uma região específica do genoma de linhagens da CVC, que contém uma inserção de 28 nucleotídeos, bem como uma base simples, característica daquela linhagem, distinguindo-se do grupo videira.

\subsubsection{Seqüenciamento do Fitopatôgeno $X$. fastidiosa (Simpson et al., 2000)}

A $X$. fastidiosa foi o primeiro organismo seqüenciado por completo no Brasil. Este projeto teve como instituições financiadoras: FAPESP (Fundação de Amparo à Pesquisa no Estado de São Paulo) e FUNDECITRUS (Fundo Paulista de Defesa da Citricultura).

Esta bactéria foi escolhida devido ao tamanho do seu genoma, importância econômica (CVC) e possibilidades de manipulação genética.

O genoma da X. fastidiosa é composto de cromossomo circular de 2.679 .305 pares de bases, dos quais um terço é de função desconhecida e $47 \%$ tem função descrita e ainda possui dois plasmídios de 51.158 e 1.285 pares de bases.

Os mecanismos associados com a patogenicidade e virulência da $X$. fastidiosa envolvem toxinas, antibióticos (resistência à penicilina) e sistema seqüestrador de íns, assim como a interação bactéria-hospedeiro é mediada por um grupo de proteínas.

Foram seqüenciados 67 genes que possuem função de retirada de ferro e outros metais da seiva da planta, podendo estando relacionado com o aparecimento dos sintomas da CVC.

Genes relacionados com adesão celular da bactéria também foram encontrados, sendo descrito dois sistemas de adesão. Um está relacionado com a adesão da bactéria na parede celular dos vasos do xilema, compreendendo uma matriz de polissacarídios extracelulares sintetizados e liberados pelos chamados "genes de goma", que sintetizam a goma xantana, esta goma fixa a bactéria na parede celular do xilema e em outras bactérias, ocorrendo o entupimento de vasos e estresse hídrico na planta. 
São 26 os genes responsáveis pelo outro sistema de adesão, codificadores de proteínas fimbrias. Estas proteínas estão provavelmente relacionadas com a adesão da bactéria no aparelho digestivo do inseto vetor.

Algumas proteínas identificadas apenas em patógenos humanos e animais estão presentes em $X$. fastidiosa, indicando uma base molecular conservada e independente do hospedeiro para a patogenicidade desta bactéria.

Também foram identificados 83 genes derivados de bacteriófagos, incluindo genes associados com virulência em outras bactérias.

Com o seqüenciamento completo do genoma da $X$. fastidiosa, obteve-se uma grande quantidade de informação que estão sendo utilizadas para o entendimento das seqüencias de genes e sua expressão, afim de fornecer bases para uma investigação experimental e acelerada das interações entre a $X$. fastidiosa e seus hospedeiros, que devem conduzir a novas abordagens para o controle e convivência da CVC.

Esta segunda fase foi denominada de análise de função, que visa incentivar e financiar grupos de pesquisa que venham utilizar informações gerada pelo seqüenciamento, tendo também suporte financeiro da FAPESP e FUNDECITRUS.

\subsection{Marcadores Moleculares}

\subsubsection{PCR ("Polymerase Chain Reaction”)}

Atualmente os termos marcadores moleculares vem sendo generalizados como marcadores genéticos, mas deve-se ter o conceito que o primeiro é todo e qualquer fenótipo molecular oriundo de um gene expresso ou de um segmento de DNA específico, e marcador genético quando avalia-se o comportamento de acordo com as leis de Mendel (Ferreira \& Grattapaglia, 1995).

O surgimento de novas técnicas que fornecem marcadores de DNA, vêem mudando a visão da análise dos genótipos dos organismos, detectando mudanças ou 
modificações existentes no DNA, para depois determinar as suas implicações (Berckmann, 1988).

A tecnologia da reação de polimerase em cadeia (PCR) foi descoberta por Kary Mullis em meados da década de 80 (Mullis \& Fallona, 1987; Saiki et al., 1985). Desde a sua concepção, esta tecnologia causou uma verdadeira revolução na biologia tanto na pesquisa visando o entendimento de processos biológicos fundamentais; como nas áreas aplicadas envolvendo diagnósticos e melhoramento genético de plantas e animais domésticos (Ferreira \& Grattapaglia, 1995).

A facilidade, rapidez, versatilidade e sensibilidade da técnica de PCR, a torna particularmente poderosa para estudos genéticos-moleculares envolvendo grande número de indivíduos de qualquer organismo vivo. Muitos métodos tradicionais de clonagem, seqüenciamento e análise de polimorfismo de DNA foram acelerados ou substituídos pelo o uso das inúmeras derivações da técnica de PCR. Uma destas derivações é a técnica de RAPD ("Random Amplified Polymorphic DNA") que envolve a amplificação simultânea de vários locos anônimos no genoma utilizando seqüências arbitrária. (Ferreira \& Grattapaglia, 1995).

PCR é uma técnica, que envolve a síntese enzimática "in vitro" de milhões de cópias de um segmento específico de DNA na presença da enzima DNA polimerase. A reação de PCR baseia-se no anelamento e extensão enzimática de um par de oligonucleotídeos (pequenas moleculas de DNA de fita simples) utilizando como iniciadores "primers" que delimitam a seqüência de DNA de fita dupla alvo da amplificação. Estes "primers" são sintetizados artificialmente de maneira que suas seqüências de nucleotídeos sejam complementares a seqüências específicas que flanqueiam a região alvo.

Um ciclo de PCR envolve 3 etapas: desnaturação, anelamento e extensão. A fita dupla do DNA alvo é desnaturada através da elevação da temperatura para 92 a $95{ }^{\circ} \mathrm{C}$. $\mathrm{Na}$ etapa de anelamento, a temperatura é rapidamente reduzida para 35 a $60{ }^{\circ} \mathrm{C}$, dependendo essencialmente do tamanho e seqüência do "primer" utilizado, permitindo a hibridização DNA-DNA de cada "primer" com as seqüências complementares que 
flanqueiam a região alvo. Em seguida, a temperatura é elevada para $72^{\circ} \mathrm{C}$ para que a enzima DNA polimerase realize a extensão a partir de cada terminal 3'dos "primers". Esta extensão envolve a adição de nucleotídeos utilizando como molde a sequência-alvo, de maneira que uma cópia desta seqüência é feita no processo. Este ciclo é repetido por algumas dezenas de vezes. Uma vez que a quantidade de DNA da seqüência dobra a cada ciclo, a amplificação segue uma progressão geométrica de maneira que, depois de apenas 20 ciclos, é produzido mais de um milhão de vezes a quantidade inicial da sequêencia alvo. Esta escala de amplificação permite, portanto, iniciar com quantidades mínimas de DNA (da ordem de alguns picogramas ou nanogramas) e terminar a reação com grandes quantidades de DNA de uma seqüência específica de interesse. A visualização dos produtos de amplificação é feita sob luz UV, após eletroforese do DNA em géis, geralmente de agarose, corados com brometo de etídio. A interpretação dos géis de PCR depende dos propósitos pelos quais se utiliza a técnica.

Em Genética Evolutiva e Ecológica a técnica é aplicada, por exemplo, para a identificar e quantificar a variabilidade genética (Fungaro \& Vieira, 1998).

Os "primers" para PCR são oligonucleotídeos de 18 a 30 nucleotídeos, os quais podem ser obtidos através de mRNA (cDNA), por meio de seqüências de DNA genômico ou também pela síntese "in vitro". Portanto, a obtenção destes segmentos iniciadores depende de um estudo prévio da seqüência de DNA a ser amplificada.

Inicialmente foi utilizado o fragmento "Klenow" da DNA polimerase de Escherichia coli para amplificação do DNA, porém esta enzima é termolábil, se desnatura ao final de cada ciclo, sendo portanto necessário a adição de nova enzima após cada ciclo, tornando o método trabalhoso e demorado (Loureiro, 1994).

Entretanto, após 1988, a técnica de PCR desenvolveu-se rapidamente com a introdução de uma DNA polimerase termoestável (Taq DNA polimerase) obtida de Thermus aquaticus (Saiki et al., 1988). Esta bactéria habita águas quentes, e por esse motivo sua enzima DNA polimerase apresenta relativa estabilidade na temperatura de desnaturação do DNA, sendo possível a sua reutilização após cada ciclo de amplificação, 
diminuindo os custos e permitindo a automatização do ciclo térmico (Henson \& French, 1993).

\subsubsection{RAPD ("Random Amplified Polymorphic DNA")}

Baseado no princípio da PCR, Williams et al. (1990) e Welsh \& McClelland (1990), descreveram uma nova classe de marcadores moleculares, os RAPDs, que tem sido extremamente útil para estudos de ordem genética ou estudos que visam esclarecer problemas relacionados à taxonomia. Esta técnica foi desenvolvida independentemente por dois grupos nos Estados Unidos. Williams et al. (1990) patentearam a tecnologia com o nome mais comumente utilizado: RAPD ("Random Amplified Polymorphic DNA"). Neste trabalho clássico, este grupo descreveu a técnica no contexto da análise Mendeliana, demonstrando a identificação de marcadores genéticos para mapeamento. Welsh \& McClelland (1990), por sua vez, propuseram a denominação mais apropriada para a técnica, chamando-a de AP-PCR ("Arbitrarily Primed-Polymerase Chain Reaction") uma vez que os "primers" possuem seqüência arbitrária, mas a amplificação tecnicamente não ocorre ao acaso e sim em lugares específicos do genoma.

$\mathrm{Na}$ técnica de RAPD, a amplificação por PCR diferencia-se da PCR "gene específica" por utilizar apenas um oligonucleotídio de seqüência arbitrária por reação. A amplificação ocorrerá quando coincidir desta mesma seqüência oligonucleotídica reconhecer um sítio de complementariedade em uma das fitas e também o mesmo sítio, porém com orientação invertida na outra fita da molécula, dentro do intervalo limite da PCR - 4Kb, utilizando-se a Taq polimerase (Williams et al., 1990).

Segundo Williams et al. (1993) o comprimento ideal do oligonucleotídio para a amplificação em RAPD é em torno de dez bases, devendo seu conteúdo GC ser em torno de 50 a $70 \%$, sendo no mínimo de $40 \%$.

O tamanho dos "primers" utilizados em RAPD são menores (normalmente 10 nucleotídeos) do que aqueles utilizados em PCR específica, justamente para aumentar a probabilidade de encontrar sítios homólogos ao "primer" dentro do intervalo limite da 
PCR. Em função dos "primers", serem escolhidos arbitrariamente, alguns deles poderão dar origem a vários produtos de amplificação enquanto outros poderão não ser capazes de gerar produtos de amplificação. Em função disto, o primeiro passo quando se deseja trabalhar com esta técnica é fazer uma seleção de "primers" que sejam apropriados para o material em estudo. A relação de amplificação pode variar de organismo para organismo, de maneira que a condução de experimentos visando o estabelecimento de condições ótimas para cada material de estudo é de grande importância.

Segundo Fungaro \& Vieira, (1998) os principais fatores a serem otimizados são a concentração de Magnésio que pode variar de 1,5 $\mathrm{mM}$ até 4,0 $\mathrm{mM}$ e concentração de DNA que pode variar de $10 \eta \mathrm{g}$ a $50 \eta \mathrm{g}$.

Os marcadores gerados por RAPD são dominantes, ou seja, não permitem verificar heterogosidade nos indivíduos em estudo, como os marcadores de RFLPs. (Ferreira \& Grattapaglia, 1995; Williams et al., 1990). Entretanto, evidências experimentais indicam que diferenças de apenas um par de bases (mutações de ponto) são suficientes para causar a não complementaridade do "primer" com o sítio de iniciação e assim impedir amplificação de um segmento (Williams et al., 1990). Outras fontes de polimorfismo podem incluir deleções de sítios de iniciação adjacentes a uma distância acima daquela que a DNA polimerase é capaz de percorrer. Assim, o polimorfismo genético detectado pelos marcadores RAPD tem natureza binária, isto é, o segmento amplificado (banda no gel) poderá estar presente ou ausente.

Para se amplificar uma determinada seqüência de DNA, deve-se efetuar as seguintes etapas: a) extração de DNA; b) reação de amplificação (PCR) e c) análise do produto amplificado em gel de eletroforese. Para a extração de DNA a ser utilizada na reação de PCR, pode-se lançar mão de métodos simplificados, uma vez que essa técnica requer uma quantidade mínima de DNA, não precisando necessariamente apresentar alto grau de pureza. Obtendo-se o molde de DNA para ser amplificado, a etapa seguinte será a reação de amplificação, onde são exigidos os componentes a seguir: desoxirribonucleotídeos trifosfatados (dNTPs), DNA polimerase, oligonucleotídeos ("primers"), que flanqueiam a região alvo e se pareiam as fitas opostas, e o DNA molde. 
Os oligonucleotídeos dispostos nas extremidades da seqüência a ser amplificada, fornecem a extremidade 3' $\mathrm{OH}$ livre para a atuação do DNA polimerase. A reação é aquecida a $90-94^{\circ} \mathrm{C}$ para a desnaturação do DNA molde, com posterior resfriamento entre $40-55^{\circ} \mathrm{C}$ para permitir o anelamento dos oligonucleotídeos com a região de homologia e um novo aquecimento de até $72^{\circ} \mathrm{C}$, propicia o alongamento ou extensão da cadeia pela Taq polimerase, completando assim o primeiro ciclo de amplificação. Nos ciclos seguintes, os oligonucleotídios irão se ligar nas fitas originais de DNA e também nas sintetizadas nos ciclos anteriores.

Os produtos de amplificação são separados por eletroforese em gel de agarose, onde os fragmentos maiores migram mais lentamente. Cada banda de DNA amplificado é o resultado da interação entre o oligonucleotídio e o DNA molde. Os polimorfismos são reconhecidos pela presença de um fragmento amplificado em um dos genótipos em relação à ausência deste mesmo fragmento em um outro genótipo, os quais são devido a diversos fatores.

$\dot{E}$ importante ressaltar que marcadores de RAPD são importantes ferramentas para se verificar as variabilidades existente entre diferentes isolados dentro de uma espécie, pois geram muito polimorfismo. De acordo com Aufauvre-Brown et al.(1992), a análise deste marcador permite a elaboração de coeficiente de similaridade que possibilita verificar o grau de relação genética entre estes isolados. Estes marcadores aliados a testes de patogenicidade podem também permitir que relações evolutivas entre raças, sejam postuladas, bem como o estudos de estrutura e evolução de populações de patógenos sejam realizados.

O RAPD pode verificar variabilidade entre isolados morfologicamente idênticos, sendo por esta razão uma importante técnica para se distinguir isolados patogênicos de não patogênicos conforme assinala Manulis et al.(1993), em Fusarium oxysporum f. sp. dianthi, como também para verificar polimorfismo entre isolados de $F$. solani sp. cucurbita (Crowhurst et al., 1991), Bipolaris mayds (Nicholson et al., 1993), Colletotrichum orbiculare (Correl et al., 1993), C. trucatum (Vasconcelos et al., 1994), 
C. gloeosporiodies (Hayden et al., 1994), Leptosphaeria maculans (Plummer et al., 1994).

Segundo Nicholson et al. (1993), a existência de fragmentos de DNA raçaespecífico gerados por RAPD podem ser clonados, seqüenciados e utilizados na construção de "primers" específicos, que podem ser empregados na identificação de raças de fitopatógenos em material doente, sem a necessidade de isolamento do microrganismo.

Pooler \& Hartung (1995a) desenvolveram "primers" específicos para Xylella fastidiosa causadora da Clorose Variegada dos Citros a partir dos produtos de amplificação obtidos nas reações de RAPD-PCR, clonando e seqüênciando as bandas obtidas somente em isolados provenientes de plantas cítricas, podendo assim diferenciar isolados quanto a origem da planta hospedeira.

Quando comparada a técnica de RAPD com outros marcadores moleculares como RFLP ('Restriction Fragment Length Polymorphism'), podemos enumerar várias vantagens. Por se basear em PCR, a técnica RAPD é muito mais sensível na detecção de polimorfismo ao nível de DNA. Por exemplo, Foolad et al.(1993) verificaram que enquanto somente $16 \%$ das sondas de RFLP revelaram polimorfismo ao nível intraespecífico em tomate, aproximadamente $63 \%$ dos "primers" RAPD testados detectaram polimorfismo no mesmo material. Eles concluiram que a tecnologia RAPD é adequada para a construção de, mapas genéticos ao nível intra-específico. Além disso a técnica de RAPD não requer o desenvolvimento prévio de uma biblioteca de sondas especificas para o organismo de interesse. Um conjunto único de "primers" arbitrários pode ser utilizado para qualquer organismo. Por não utilizar sondas, é eliminada a necessidade de isótopos radioativos ou marcação não-radioativa. Outra grande vantagem é a quantidade mínima de DNA necessária para a análise genotípica de um indivíduo. Enquanto para RFLP são necessárias dezenas de microgramas de DNA, para RAPD são necessários apenas dezenas de nanogramas, ou seja 3 ordens de magnitude menos.

Os segmentos RAPD uma vez amplificados e separados por eletroforese podem ser facilmente isolados do gel, mantidos na forma de uma biblioteca genômica "in vitro" 
sem necessidade de vetores, e amplificados via PCR sempre que necessário (Ferreira \& Grattaplagia, 1995).

\subsubsection{Utilização do RAPD em estudos bacteriológicos}

Em bactérias, Williams et al. (1990) sugerem que o número de fragmentos de DNA amplificados por RAPD somente pode ser explicado pelo pareamento errado entre "primers" e o DNA molde, pois seu genoma é menor que o de fungo e plantas. Entretanto, Farber \& Addison (1994) utilizando duas extrações de DNA de Listeria monocytogenes, observaram resultados idênticos com estes DNAs, repetindo um mesmo "primer" mostrando a reprodutibilidade desta técnica para bactérias.

Em estudo de tipagem de diferentes linhagens de Escherichia coli utilizando as técnicas de RAPD e MLEE (multilocus enzyme eletrophoretictyping method) Wang et al. (1993) concluiram que os marcadores de RAPD são mais eficiente, pois utilizando 5 "primers" combinados, foi possível distinguir 74 de 75 isolados desta bactéria, o que não foi possivel com a utilização de diagnóstico eletroforético, utilizando 20 enzimas diagnóstico. Portanto a técnica de RAPD mostra-se muito sensivel para subtipar diferentes isolados bacterianos explorando a variabilidade existente dentro de um mesmo grupo.

Harrison et al. (1992), demonstraram que, o uso de "primers" ao acaso, selecionados na ausência de uma seqüência alvo, mostrou-se efetivo na produção de amplificações do DNA que produziram "fingerprints" os quais foram característicos de organismos individuais. A amplificação do DNA por "primers" ao acaso foi aplicada ao DNA de isolados de Rhizobium leguminosarum biovar trifolli. Os produtos de amplificação foram produzidos usando-se "primers", e os "fingerprints" resultantes permitiram a diferenciação das estirpes. A habilidade de produzir padrões de amplificação variados, de diferentes isolados de Rhizobium, especialmente direto a partir dos nódulos, dá a este método um potencial de utilização no exame de estruturas e relação genéticas nas populações de Rhizobium. 
Martin-Kearley et al. (1994), estudaram 80 cepas regionais de Vibrio, isoladas a partir de águas frias sazonais próximas a Terra-Nova (Canadá), e algumas cepas referência, pertencentes a espécie Vibrio splendidus e Vibrio ordalii. As espécies regionais foram isoladas de alga marrom Alaria esculenta e do marisco gigante Placopecten magellanicus. Estas cepas, foram agrupadas de acordo com sua reação para arginina-dehidrolase e analisadas numericamente. Depois de estudadas as características fenotípicas as estirpes foram submetidas a reação de RAPD- PCR, e verificou-se que as estirpes regionais foram significativamente diferentes de $V$. splendidus e $V$. ordalii. Em geral, as estirpes regionais isoladas de algas marinhas formaram um grupo a parte daquelas isoladas do marisco, indicando a variabilidade dentro do grupo.

Dentro desse contexto, a técnica de RAPD foi utilizada para distinguir isolados ambientais de Legionella pneumophila (Sandery et al., 1994), e também para distinguir isolados de Bacillus spp., Bacillus licheniformis (Stephan et al., 1994) e Vibrio sp. (Martin-Kearley et al., 1994).

Sousa (1996), estudando variabilidade por RAPD de bactérias do gênero Bacillus isoladas endofiticamente de milho, conclui ampla variabilidade genética entre os 13 isolados estudados, diferindo os produtos de amplificação, em sua maioria, daqueles obtidos para as espécies de referência: Bacillus megatearium e Bacillus subtilis, de origem não endofitica.

Araújo (1996), analisando bactérias isoladas endofiticamente de porta-enxertos de citros via marcadores de RAPD conclui a formação de um grupo muito similar constituído por 9 isolados identificados como Ervinia herbicola, sendo o coeficiente de similaridade médio de $87,5 \%$.

Pooler \& Hartung (1995b) estudando geneticamente linhagens da bactéria Xylella fastidiosa por meio de marcadores de RAPD, analisaram um total de 11 linhagens, isoladas de amexeira, amendoeira, amoreira, citros, elmo e videira, concluindo a existência de 5 grupos de bactérias. Rosato et at. (1998) também analisou a diversidade genética de isolados de $X$. fastidiosa por RAPD utilizando 8 "primers" para um total de 
37 isolados de citros, um de amexeira, dois de cafeeiro, e um de videira, demostrando uma similaridade média de $80 \%$ entre os isolados de plantas cítricas afetada pela CVC.

Girão et al., 1999 conduziram experimento de caracterização de amostras de $E$. coli enteropatogênica (EPEC) típicas e atípicas do sorogrupo O55 através da análise por RAPD. Foram analisadas 41 amostras de E. coli, sendo que todas as amostras EPEC 055 típicas ficaram localizadas em 2 grupos e pertenciam ao sorotipo O55:H6, enquanto um outro grupo compreendia todas as amostras atípicas, as quais eram sorotipo O55:H7. Os três grupos apresentaram também amostras imóveis. A técnica de RAPD de grande utilidade em estudos epidemiológicos da infecção pela E. coli $\mathrm{O} 55$.

Esta técnica, portanto permite determinar distâncias e similaridades entre materiais genéticos de origem bacteriana, possibilitando a elaboração de dendogramas, que tentarão elucidar questões a respeito da evolução filogenética e variabilidade genética dentro de um mesmo grupo.

\subsection{Resistência a drogas}

Com a descoberta da penicilina por Fleming, em 1929, na Inglaterra, iniciou-se a era da antibióticoterapia. Surgiram então inúmeras drogas antimicrobianas e, ao mesmo tempo, vários estudos sobre a resistência bacteriana, tentando explicar a causa deste fenômeno. Logo se percebeu que a introdução de antimicrobianos na terapêutica proporcionou a seleção de mutantes resistentes que sobreviviam e se multiplicavam enquanto as sensíveis eram eliminadas. Um agravante do problema foi quando pesquisadores observaram a rápida disseminação por meio da transferência da resistência a drogas para células sensíveis. Somente após extensivos estudos genéticos e bioquímicos puderam elucidar os acontecimentos.

\subsubsection{Genética da resistência a drogas}


Os determinantes genéticos para a resistência a drogas estão situados no cromossomo, e/ou em elementos extracromossômicos chamados de plasmídios R.

A resistência cromossomica pode ser obtida por meio de mutações em um só gene (monogênica) ou envolvendo diversos genes (poligênica). Os dois tipos são eficientes, sendo que, no primeiro, a aquisição é feita em um só passo, alcançado rapidamente níveis de resistência bastante altos, enquanto no segundo tipo são necessários vários passos até a bactéria atingir níveis satisfatórios de resistência (Campos et al., 1976).

Segundo Azevedo (1998), a descoberta de plasmídios R ocorreu em 1955, no Japão a partir do relacionamento de uma Shigella resistente a sulfas, estreptomicina, cloranfenicol e tetraciclinas e uma E. coli, com uma parte do plasmídio R, assim chamado por transferir resistência múltipla a drogas (Resistence Transfer Factor). O plasmídio R pode ser considerado como um elemento genético que tem uma parte (RTF), com um número de marcadores genéticos que confere resistência a múltiplas drogas.

A resistência determinada por genes plasmidiais é muito mais comum do que a resistência cromossômica em bactérias. Os plasmídios com estes genes oferecem vantagens seletivas para suas células hospedeiras na presença de antimicrobianos.

Conforme Stainer et al., (1986), esses plasmídios contêm genes que codificam para síntese de enzimas capazes de metabolizar o antibiótico, por exemplo, a produção de penicilinases por certas cepas de Staphylococcus aureus.

Romeiro et al. (1993), testaram dezenas de espécies de fitobactérias frente a dezenas de antibióticos, encontrando um padrão típico de sensibilidade. Significando para os autores que isolados nunca expostos a antibióticos, dentro de uma mesma espécie apresentavam-se resistentes a um mesmo grupo de antibióticos, numa evidência clara de resistência múltipla ocorrendo naturalmente.

\subsection{Modo de ação dos antibióticos}

2.4.1. Penicilinas (Lacaz, 1975; Spinosa, 1996) 
As penicilinas são polipeptídios, cuja a estrutura química tem um anel $\beta$ lactâmico, sendo derivados do ácido 6-amino-penicilânico. Esse grupo de antibiótico impedem a síntese da parede celular, estrutura responsável nas bactérias pela proteção, sustentação e manutenção da sua forma. É importante ressaltar que as penicilinas não são capazes de atuar sobre a parede celular já formada; a condição essencial para a ação bactericida destes antibióticos é que os microrganismos estejam se multiplicando. As penicilinas são classificadas de acordo com as modificações na molécula do ácido 6amino-penicilânico e quanto ao seu espectro de ação, sendo divididas em: penicilinas naturais, penicilinas biossintéticas, penicilinas resistente a penicilinase, penicilinas de amplo espectro de ação, nesse último grupo estão inclusas a ampicilina, amoxilina e penicilinas de $2^{\mathrm{a}}, 3^{\mathrm{a}}$ e de $4^{\mathrm{a}}$ geração.

\subsubsection{Aminoglicosídios (Lacaz, 1975; Spinosa, 1996)}

Os aminoglicosídios são antibióticos constituídos por um núcleo de hexose unido a aminoaçúcares, por ligações glicosídicas ; por isso são chamados também de aminociclitóis. A maioria dos antibióticos deste grupo é produzida pelos microrganismos Streptomyces griseus, S. kanamyceticus, S. fradiae e Micronospora purpurea); contudo, há também os semi-sintéticos. Dentro deste grupo os antibióticos mais comumente utilizados são: estreptomicina, neomicina, canamicina e gentamicina.

Estes antibióticos interferem na síntese protéica bacteriana, promovendo a formação de proteínas defeituosas. Os aminoglicosídios ligam-se à subunidade $30 \mathrm{~S}$ ribossoma, provocando a leitura incorreta do código genético e, consequentemente, permitem a incorporação de aminoácidos incorretos na cadeia polipeptídica que está sendo formada no ribossoma. Esta proteína defeituosa que se forma na presença dos aminoglicosídios é fundamental para o metabolismo bacteriano, levando à morte celular; portanto, os aminoglicosídios são antibióticos bactericidas. 
Os aminoglicosídios têm espectro de ação relativamente curto, com atividades predominantes sobre microrganismos Gram-negativos.

2.4.3. Polimixinas (Lacaz, 1975; Spinosa, 1996)

São antibióticos de estrutura polipeptídica, produzidos pelo Bacillus polymyxa. Dentre as várias polimixinas $(\mathrm{A}, \mathrm{B}, \mathrm{C}, \mathrm{D}, \mathrm{E}$ e M) apenas a $\mathrm{B}$ a $\mathrm{E}$ têm uso terapêutico. A polimixina $\mathrm{E}$ é também denominada colistina ou colimicina; é menos tóxica, porém, sua atividade antimicrobiana é menor que a da polimixina $B$.

O espectro de ação é relativamente curto, atuando preferencialmente sobre bacilos entéricos Gram-negativos (Escherichia coli, Enterobacter aerogenes, Klebsiella spp e Pseudomonas aeruginosa). Todas as bactérias Gram-positivas são resistentes às polimixinas

As polimixinas atuam na membrana citoplasmática da bactéria, ligando-se a radicais fosfatos. Esta ligação desorganiza a estrutura da membrana citoplasmática, fazendo-a perder sua seletividade e permitindo a saida de pequenas moléculas para o exterior da bactéria. São antibióticos bactericidas e raramente as bactérias sensíveis adquirem resistência.

2.4.4. Tetraciclinas (Lacaz, 1975; Spinosa, 1996)

As tetraciclinas são antibióticos produzidos por diversas espécies de Streptomyces, são classificados como antibióticos de largo espectro de ação antimicrobiana. As tetraciclinas atuam sobre bactérias Gram-positivas e Gram-negativas.

O mecanismo de ação das tetraciclinas se baseia na inibição da síntese protéica dos microrganismos sensíveis, ligando-se aos ribossomas. Estes antibióticos ligam-se à subunidade $30 \mathrm{~S}$ do ribossoma do microrganismo, impedindo que o RNAt se fixe ao ribossoma, e com isso, a síntese protéica é inibida. São antibióticos bacteriostáticos. A resistência bacteriana adquirida é mediada principalmente por plasmídios, que reduzem a 
captação das tetraciclinas pela célula bacteriana; algumas bactérias podem também ser induzidas a sintetizar enzimas que inativam este antibiótico.

\subsubsection{Cloranfenicol (Lacaz, 1975; Spinosa, 1996)}

Antibiótico produzido por Streptomyces venezuelae, também pode, atualmente, ser obtido por síntese laboratorial. É considerado um antibiótico de largo espectro de ação, atuando sobre bactérias Gram-positivas e Gram-negativas.

O cloranfenicol inibe a síntese protéica dos microrganismos, ligando-se à subunidade $50 \mathrm{~S}$ e, desta forma interfere com a formação do peptídio pelo bloqueio da enzima peptidiltransferase. Assim, impede o alongamento da cadeia polipeptídica; são antibióticos bacteriostáticos.

A resistência bacteriana na sua maioria é mediada por plasmídios, que têm a capacidade de produzir enzimas que inativam o cloranfenicol.

\subsubsection{Rifamicinas (Lacaz, 1975; Spinosa, 1996)}

As rifamicinas ou rifocinas constituem um grupo de antibióticos (rifamicina $A, B$, C e D) obtidos de Streptomyces mediterranei; destes, o mais ativo é a rifamicina B, a partir da qual foram obtidos vários derivados semi-sintéticos, como a rifamicina $\mathrm{SV}$, a rifamida (rifamicina $\mathrm{M}$ ) e a rifampicina (rifampim).

O espectro de ação antimicrobiano das rifamicinas pode ser considerado intermediário. A rifamicina SV atua sobre microrganismos Gram-positivos; a rifamida, além destes, atua sobre micobactérias e algumas bactérias Gram-negativas; e a rifampicina possui um maior espectro de ação, atuando sobre bactérias Gram-positivas, Gram-negativas, micobactérias, além de estafilococos produtores de penicilinase.

As rifamicinas interferem com a RNA-polimerase, impedindo a transcrição de informações genéticas. Estes antibióticos formam complexos estáveis com o RNApolimerase dos microrganismos sensíveis, sendo a inibição da atividade enzimática 
proporcional à quantidade de complexo formado. As rifamicinas têm ação primariamente bacteriostática, porem observa-se efeito bactericida, devido ao fato dos microrganismos apresentarem sensibilidade a concentrações muito baixas destes antibióticos.

A resistência bacteriana cromossômica desenvolve-se com relativa facilidade, motivo pelo qual costuma-se associá-la a outros antimicrobianos

\subsection{Antibióticos como Marcas Genéticas}

Em estudos de transformação bacteriana, onde há introdução de um DNA exógeno em um hospedeiro, a ferramenta mais utilizada são plasmídios que possuem marcas genéticas. (Astolfi $\mathrm{F}^{\circ}$. et al., 1985).

As marcas genéticas mais comumente usadas são os genes que conferem resistência a antibiótico como ampicilina, tetraciclina, cloramfenicol, e canamicina (neomicina) Estas marcas conferem um novo fenótipo à bactéria, o qual permite o fácil reconhecimento das células transformadas. (Sambrook et al., 1989).

Entretanto, quando busca-se a transformação de uma bactéria e pretende-se selecionar os transformantes por resistência a antibióticos; é necessário o conhecimento prévio de quais antibióticos este microrganismo demonstra resistência natural. Este tipo de informação é importante na construção do vetor de transformação e conseqüentemente para a seleção dos transformantes.

\subsection{Metodologias para Antibiogramas}

\subsubsection{Método da difusão}

Nos métodos de difusão em agar, apresenta sempre o mesmo fato fundamental, consistindo na difusão da droga no meio sólido. Encontramos a formação de um gradiente de concentrações do antibiótico a partir de seu ponto de aplicação. Quanto mais distante do ponto de aplicação do antibiótico, menor a sua concentração. Portanto, 
quanto mais distante do ponto de aplicação do antibiótico ocorrerá a inibição do crescimento bacteriano, maior será a sensibilidade da referida droga (Amato Netto et al., 1985).

\subsubsection{Método do disco de papel}

O antibiograma de difusão pelo método do disco é o mais utilizado, não só pela facilidade como pela rapidez do resultado obtido. Em 1960, Bauer et al., publicaram uma técnica (método Kirby-Bauer), a qual, além de procurar consolidar o emprego de um único disco para cada antibacteriano, apresentar também metodologia simples, cujo os resultados oferecem melhor correlação com o método da Concentração Mínima Inibitória (C.I.M.).

A fim de se obter um resultado ainda mais rápido, o teste pode ser realizado antes mesmo da completa identificação do microrganismo, bastando para isso que os discos sejam aplicados ao meio quando da semeadura da cultura pura. $\mathrm{O}$ resultado do antibiograma é dado pelo diâmetro do halo de inibição medido em milímetros e padronizado de acordo com a droga e com a concentração utilizada de acordo com o microrganismo. Em geral o resultado é expresso em sensível, moderadamente sensível e resistente (Tavares, 1988).

\subsubsection{Método das diluições}

O método das diluições consiste em se fazer diluições seriadas do antibiótico em meio de cultura líquido adequado ao crescimento do microrganismo, cuja sensibilidade ou resistência se quer conhecer. $O$ tubo de menor concentração do antibiótico capaz de impedir o aparecimento de turvação ou crescimento após um determinado tempo de incubação é considerado como o poder bactericida do antibiótico. Essa concentração é referida como Concentração Mínima Inibitória (C.I.M.). 
Por esse método não é possível evidenciar a presença de contaminantes e o aparecimento de clones resistentes dentro de uma mesma amostra bacteriana. Também esse método de exame não pode ser executado, em culturas mistas e somente com a bactéria isolada, o que requer mais tempo e, portanto, maior demora na obtenção dos resultados (Petersdorf \& Plorde, 1963; Fava Netto, 1975).

Por outro lado, esse método apresenta vantagens muito importantes já que permite a verificação quantitativa da sensibilidade. Por esse método pode-se verificar o antagonismo e sinergismo dos antibióticos (Jawetz et al., 1955, Julis \& Gaikhorst, 1958; Petersdorf \& Plorde, 1963).

\subsection{Microrganismos endofíticos de citros}

Endófitos são microrganismos que podem ser isolados de tecidos vegetais desinfectados superficialmente ou do interior de tecidos vegetais, e que não causam aparentemente nenhum dano às plantas (Hallmann et al, 1997).

Bactérias endofiticas, da mesma forma que fitopatógenos apresentam a capacidade de penetrar na planta e de se disseminarem sistematicamente no hospedeiro habitando de forma ativa o apoplasto (Mahaffee et al., 1997; Quadt-Hallmann et al., 1997b; James \& Olivares, 1998; Reinhold-Hurek \& Hurek, 1998), vasos condutores (Ruppel et al., 1992; Bell et al., 1995; Mahaffee et al., 1997; Hallmann et al., 1997; James \& Olivares, 1998) e ocasionalmente pode haver colonização intracelular (James et al., 1994; Quadt-Hallmann \& Kloepper, 1996; Quadt-Hallmann et al., 1997a). Nestes habitats, as bactérias devem induzir alterações fisiológicas no hospedeiro, além de alterar a população de outros microrganismos associados à planta.

Bactérias endofiticas podem ser importantes candidatas para o controle biológico, visto que colonizam um nicho ecológico semelhante àquele ocupado por fitopatógenos (Hallmann et al, 1997). Além disso, inúmeros trabalhos têm mostrado que microrganismos endofiticos exibem potencial como agente de controle biológico contra 
diversos fitopatógenos (Azevedo et al, 2000; Sturz \& Matheson, 1996; M'Piga et al. 1997; Sharma \& Nowak, 1998; Duijff et al., 1997; Sturz et al, 1998).

Araújo (1996) realizou um levantamento da população bacteriana endofítica de 10 porta-enxertos de Citros. Este estudo mostrou que Pantoea agglomerans foi a bactéria endofitica mais freqüente nas plantas analisadas. Outras espécies de bactérias endofiticas também foram isolados e que representam os gêneros Bacillus, Pseudomonas e Alcaligenes. Num estudo mais abrangente e que envolveu a caracterização da microbiota endofitica de plantas cítricas sadias, naturalmente resistentes e afetadas pela CVC foi verificado que existem pelo menos quatro grupos principais de bactérias endofiticas, $P$. agglomerans, Enterobacter cloacae, Methylobacterium extorquens e Curtobacterium flaccumfaciens (Azevedo et al., 2000).

Araújo (2000), constata provável associação entre $X$. fastidiosa e bactérias endofiticas, visto que plantas assintomáticas, apresentam uma frequêencia maior de $C$. flaccumfaciens, enquanto plantas afetadas pela CVC são intensamente colonizadas por Methylobacterium spp. 


\section{MATERIAIS E MÉTODOS}

\subsection{Materiais}

\subsubsection{Coleta das amostras vegetais}

O material vegetal utilizado no presente trabalho foi coletado pelo FUNDECITRUS (Fundo Paulista de Defesa da Citricultura), em regiões do Estado de São Paulo onde a incidência de CVC.

\subsubsection{Plantas cítricas empregadas no isolamento}

Foram coletadas folhas e ramos de Citrus sinensis, que estavam com sintomas visíveis e característicos da Clorose Variegada dos Citros. Foram utilizadas plantas com idade acima de 5 e 6 anos.

\subsubsection{Isolados de $X$. fastidiosa}

Foram incluídos neste trabalho 4 linhagens de $X$. fastidiosa que não foram isolados pelo autor, sendo eles: o isolado referência 9a5c, dois de cafeeiro cedidos pelo Fundo Paulista de Defesa da Citricultura (FUNDECITRUS), sendo um da região de São José do Rio Preto e o outro da região de Marília e por último um isolado de videira (EUA), cedido pelo Dr. Rui Pereira Leite (IAPAR/Londrina). 


\subsubsection{Microrganismos endofíticos de citros}

Os microrganismos endofiticos utilizados para verificação de interação "in vitro" com X. fastidiosa, fazem parte da coleção do Setor de Genética de Microrganismo, Departamento de Genética da Escola Superior de Agricultura "Luiz de Queiroz", Piracicaba, SP.

Utilizou-se isolados bacterianos de Pantoea agglomerans, Curtobacterium flaccumfaciens e Methylobacterium sp..

\subsection{Meios de Cultura}

3.2.1. Meio PW - "Periwinkle Wilt Agar", (Davis et al., 1981)

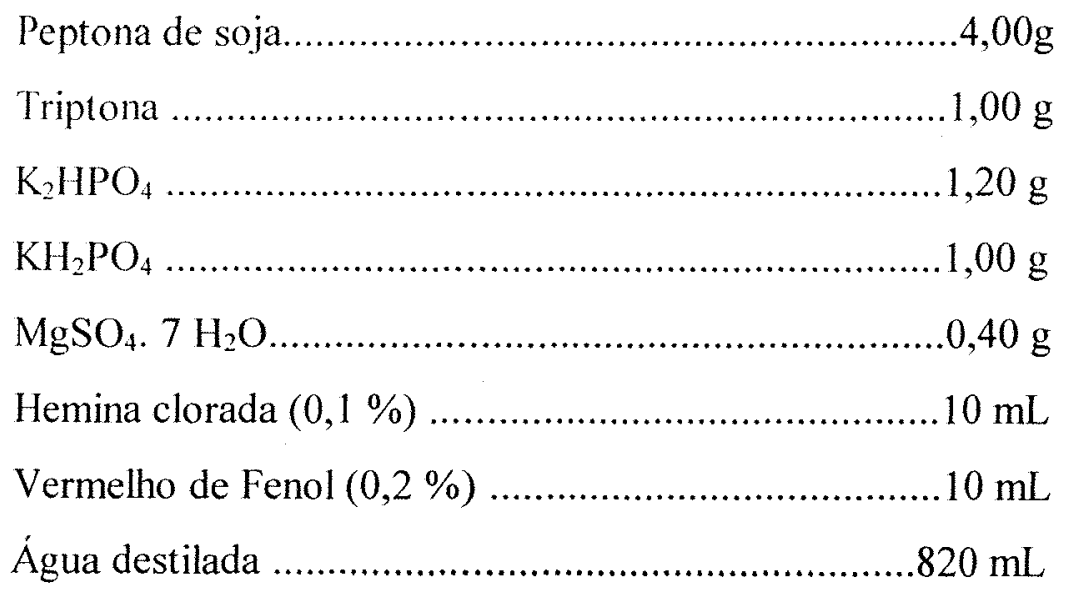

Autoclavado por 20 minutos à $120^{\circ} \mathrm{C}$. Após a autoclavagem, com o meio resfriado por volta de $45^{\circ} \mathrm{C}$, adicionar:

L-Glutamina $(4 \%)$........................................ $100 \mathrm{~mL}$

Soro Albumina Bovina V (BSA) $(10 \%) \ldots \ldots \ldots \ldots \ldots \ldots . \ldots 6 \mathrm{~mL}$

As soluções de Glutamina e BSA são esterilizados por filtragem (filtro de $0,2 \mu \mathrm{m}$ ) antes de serem adicionados ao restante do meio pH 6,8 
3.2.2. Meio BCYE (Wells et al., 1981)

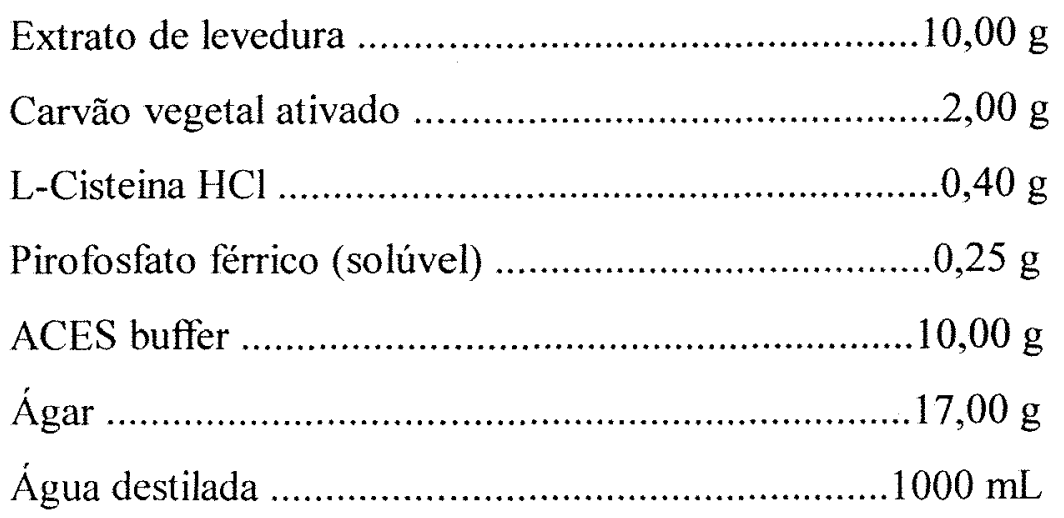

\subsection{Soluções e Tampões}

\subsubsection{Solução de Glutamina $4 \%$}

Glutamina …...........................................................

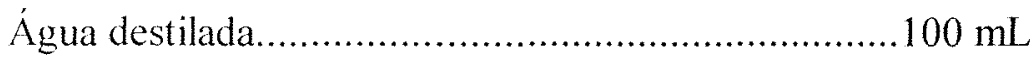

3.3.2. Solução de Soro albumina bovina $10 \%$

Soro albumina bovina .........................................10,00 g

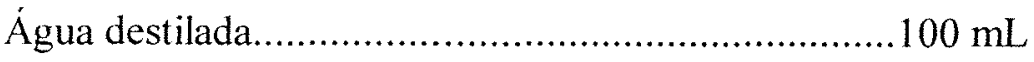

\subsubsection{Solução de Hemina clorada $0,1 \%$}

Hemina clorada ….................................................... $10 \mathrm{~g}$

Hidróxido de sódio ................................................. $0,20 \mathrm{~g}$

Água destilada ................................................. 
3.3.4. Solução de Vermelho de fenol $0,2 \%$

Vermelho de fenol

$0,20 \mathrm{~g}$

Água destilada $100 \mathrm{~mL}$

\subsubsection{Solução de Hipoclorito de Sódio 1\%}

Hipoclorito de Sódio $1 \%$ $50 \mathrm{~mL}$

Água destilada $.50 \mathrm{~mL}$

\subsubsection{Solução Álcool etílico $70 \%$}

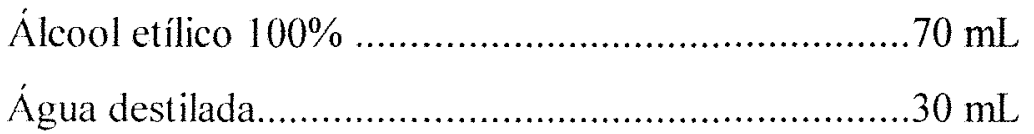

\subsubsection{Solução de cristal violeta}

Solução A: Cristal violeta ...................................2,00 g Etanol 95\%.....................................20 mL

Solução B: Oxalato de amônio ................................0,80 g Água destilada ...................................80 mL

As soluções A e B foram misturadas e estocadas.

\subsubsection{Solução de lugol}

Iodo $1,00 \mathrm{~g}$

Iodeto de potássio. $2,00 \mathrm{~g}$ 


\subsubsection{Solução de Safranina}

Solução estoque:

Safranina $2,50 \mathrm{~g}$

Etanol 95\% $.100 \mathrm{~mL}$

Solução de trabalho:

Solução estoque. $10 \mathrm{~mL}$

Água destilada $.90 \mathrm{~mL}$

\subsubsection{Solução de RNase}

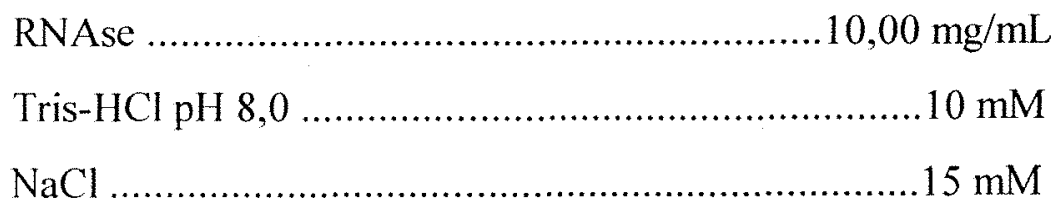

3.3.11. Solução de fenol saturada (modificado Sambrook et al., 1989)

Foram solubilizado $50 \mathrm{~g}$ de fenol cristalizado em banhomaria a $65^{\circ} \mathrm{C}$ e adicionado um volume de tampão Tris $\mathrm{HCl} 0,5 \mathrm{M} \mathrm{pH} \mathrm{8,0.}$ A solução foi submetida a agitação durante 30 minutos, a fim de equilibrar o $\mathrm{pH}$. A fase aquosa foi retirada e o procedimento repetido com Tris $\mathrm{HCl} 0,1$ $\mathrm{M}, \mathrm{pH}$ 8,0. Em seguida, foi adicionado $1 / 10$ do volume final de tampão Tris $\mathrm{HCl} 0,1 \mathrm{M}$ pH 8,0 e estocado em frasco escuro a $4^{\circ} \mathrm{C}$.

\subsubsection{Clorofane}

Fenol saturado $100 \mathrm{~mL}$

Clorofórmio $96 \mathrm{~mL}$

Álcool isoamílico $4 \mathrm{~mL}$ 


\subsubsection{Clorofil}

Clorofórmio $.96 \mathrm{~mL}$

Álcool isoamílico $4 \mathrm{~mL}$

\subsubsection{Tampão TE}

Tris-HCl $1 \mathrm{M} \mathrm{pH}$ 7,5....................................... $10 \mathrm{~mL}$

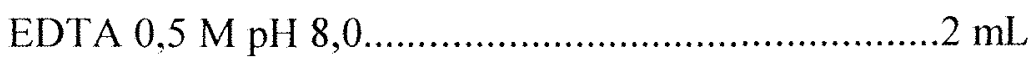

O volume foi completado para $1000 \mathrm{~mL}$ com água destilada e a solução esterilizada.

\subsubsection{Tampão TEB $10 \mathrm{X}$}

Tris-HCl $1 \mathrm{M} \mathrm{pH}$ 7,5...................................... $10 \mathrm{~mL}$ Ácido bórico............................................................. $55,00 \mathrm{~g}$

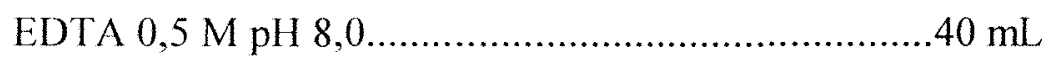

O tampão foi autoclavado e mantido a $4{ }^{\circ} \mathrm{C}$. No momento do uso, o mesmo foi diluído com água Milli-Q para a obtenção da concentração desejada.

\subsubsection{SDS $10 \%$}

SDS $10,00 \mathrm{~g}$

Água destilada $.90 \mathrm{~mL}$

Aquecer a solução até $68{ }^{\circ} \mathrm{C}$ para dissolução e ajustar o volume para $100 \mathrm{~mL}$, armazenar a $4{ }^{\circ} \mathrm{C}$. 


\subsubsection{Proteinase $K$}

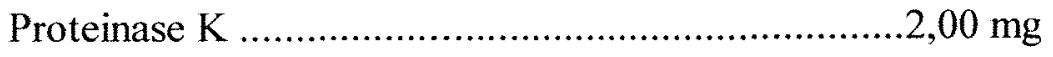

Água Milli-Q ...................................................... $100 \mu \mathrm{L}$

\subsubsection{8. $\mathrm{NaCl} 5 \mathrm{M}$}

$\mathrm{NaCl}$

$29,20 \mathrm{~g}$

Água destilada ..................................................... $80 \mathrm{~mL}$

Ajustar o volume para $1000 \mathrm{~mL}$ e autoclavar por 20 minutos

a $120^{\circ} \mathrm{C}$.

3.3.19. СТAB $10 \%$

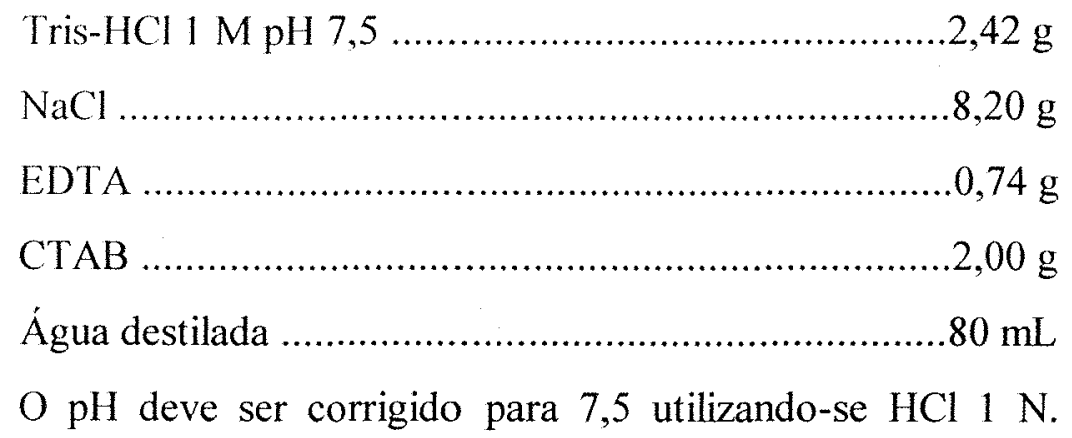
Aquecer a solução para melhor dissolução 15 minutos a $120^{\circ} \mathrm{C}$. Utilizar a solução à temperatura ambiente.

\subsubsection{Tampão de amostra}

Azul de bromofenol ............................................... $0,25 \%$

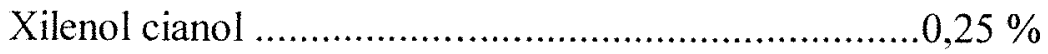

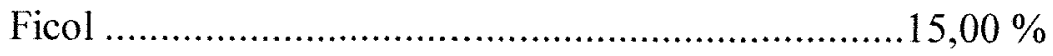




\subsubsection{Gel de agarose $0,8 \%$}

Agarose

$.0,80 \mathrm{~g}$

Tampão TEB $1 \mathrm{X}$ $.100 \mathrm{~mL}$

\subsubsection{Gel de agarose $1,4 \%$}

Agarose $1,40 \mathrm{~g}$ Tampão TEB $1 \mathrm{X}$ $100 \mathrm{~mL}$

\subsubsection{Solução estoque de dNTP's}

Os 4 dNTP's ( dATP, dTTP, dCTP, dGTP) foram adquiridos (Gibco) numa concentração de $100 \mathrm{mM}$. Para uso foram misturados e diluídos em água Milli-Q de modo a se obter uma concentração estoque de $2,5 \mathrm{mM}$ de cada dNTP.

\subsubsection{Solução estoque de brometo de etídio $1,0 \%$}

Brometo de etídio $.100 \mathrm{mg}$

Água destilada $100 \mathrm{~mL}$

O brometo de etídio foi dissolvido em água destilada durante uma hora com agitação, depois estocado a $4{ }^{\circ} \mathrm{C}$, em frasco cor de ambar.

\subsubsection{Solução Tris-HCl $1 \mathrm{M}$}

Tris base $121,10 \mathrm{~g}$ Água Milli-Q $800 \mathrm{~mL}$

$\mathrm{O} \mathrm{pH}$ foi ajustado para 7,5 com $\mathrm{HCl}$ concentrado e o volume 
completado para $1000 \mathrm{~mL}$ com água Milli-Q. A solução foi distribuída em frascos $(100 \mathrm{~mL})$, os quais foram esterilizados por 20 minutos a $120^{\circ} \mathrm{C} \mathrm{e}$ estocados à temperatura ambiente.

\subsubsection{Solução de EDTA 0,5 M (pH 7,5)}

$\mathrm{Na}_{2}$ EDTA. $2 \mathrm{H}_{2} \mathrm{O}$ $186,10 \mathrm{~g}$

Água destilada $800 \mathrm{~mL}$

$\mathrm{O}$ pH foi ajustado para 7,5 com $\mathrm{NaOH}$ sólido. Após a dissolução completa do EDTA, o volume foi completado para $1000 \mathrm{~mL}$ com água destilada. A solução foi esterilizada por 20 minutos a120 ${ }^{\circ} \mathrm{C}$ e estocados à temperatura ambiente.

\subsubsection{Tampão TAE 50X}

Tris base $242,00 \mathrm{~g}$

Ácido acético glacial ...........................................57 mL

EDTA $0,5 \mathrm{M}(\mathrm{pH} 8,0)$.......................................100 mL

$\mathrm{O}$ volume foi acertado para $1000 \mathrm{~mL}$ com água Milli-Q. O tampão foi esterilizado por 20 minutos al $20{ }^{\circ} \mathrm{C}$ e mantido a $4{ }^{\circ} \mathrm{C}$. No momento do uso, o mesmo foi diluído com água Milli-Q para a obtenção da concentração desejada.

\subsection{Marcador de peso molecular}

\subsubsection{DNA Ladder $100 \mathrm{pb}$ (GIBCO)}

Ladder $100 \mathrm{pb}$ $.10 \mu \mathrm{L}$ 
TE $.70 \mu \mathrm{L}$

Tampão de amostra .............................................20

Tampão de estoque: $10 \mathrm{mM}$ Tris- $\mathrm{HCl}(\mathrm{pH} 7,5) ; 1,0 \mathrm{mM}$

EDTA

\subsection{Componentes da Reação de RAPD - PCR}

3.5.1 "Primers" para deteç̧ão da X. fastidiosa via PCR (Pooler \& Hartung, 1995a)

Tabela 1 - "Primers" para deteç̧ão de $X$. fastidiosa via PCR

\begin{tabular}{lll}
\hline Primer & Sequência $5^{\prime} \rightarrow 3^{\prime}$ & Temp. de anelamento
\end{tabular}

$\left({ }^{\circ} \mathrm{C}\right)$

\begin{tabular}{lll}
\hline CVC -1 & AGATGAAAACAATCATGCAAA & 62 \\
$272-2$ int. & GCCGCTTCGGAGAGCATTCCT & 62 \\
$272-1$ & AGCGGGCCAATATTCAATTGC & 68 \\
$272-2$ & AGCGGGCCAAAACGATGCGTG & 68 \\
\hline
\end{tabular}

\subsubsection{Tampão de amplificação RAPD-PCR}

O tampão utilizado foi o da marca CIBCO BRL sendo fornecido $10 \mathrm{X}$ concentrado e composto por $\mathrm{KCl} 500 \mathrm{mM}$, Tris $\mathrm{HCl}(\mathrm{pH}$ 8,4) $200 \mathrm{mM}$ e isento de magnésio. O magnésio em solução é fornecido na concentração de $50 \mathrm{mM}$ em frasco separado, por este mesmo fabricante. $\mathrm{O}$ tampão de amplificação e a solução de magnésio foram estocado a $-20^{\circ} \mathrm{C}$.

\subsubsection{Enzima Taq polimerase}

A enzima utilizada foi a da GIBCO BRL sendo fornecidas 
em tubos de 250 unidades em $50 \mu \mathrm{L}$ ou em tubos de 100 unidades em 20 $\mu \mathrm{L}$ (ambas com 5 unidades por $\mu \mathrm{L}$ ). A enzima deve ser estocada a $-20^{\circ} \mathrm{C}$.

\subsection{4. "Primers" para RAPD (Operon Technologies)}

Os "primers" foram fornecidos em kits em quantidade aproximada de $14 \mu \mathrm{g}$, sob a forma de "pellets" liofilizados. A estes, adicionou-se água Milli-Q esterilizada a fim de obter uma solução estoque na concentração de $50 \mu \mathrm{M}$, utilizando-se o peso molecular do "primer" individual dado pelo fornecedor. A seguir, estes foram diluidos a uma concentração de $4 \mu \mathrm{M}$ e estocados a $-20^{\circ} \mathrm{C}$.

\subsection{Antibióticos}

\subsubsection{Antibióticos impregnados em disco de papel}

Os discos de antibióticos utilizados foram os da marca CECON (Centro de Controle e Produtos para Diagnósticos LTDA), com concentrações já determinadas pelo fabricante.

$\mathrm{Na}$ Tabela 2 encontram-se os antibióticos com suas respectivas concentrações. 
Tabela 2 - Discos de antibióticos com suas respectivas concentrações

\begin{tabular}{ll}
\hline Antibiótico & Concentração \\
\hline \hline Penicilina G & $10 \mathrm{mcg}$ \\
Ampicilina & $10 \mathrm{mcg}$ \\
Canamicina & $30 \mathrm{mcg}$ \\
Vancomicina & $30 \mathrm{mcg}$ \\
Cloranfenicol & $30 \mathrm{mcg}$ \\
Rifamicina & $30 \mathrm{mcg}$ \\
Polimixina B & $30 \mathrm{mcg}$ \\
\hline
\end{tabular}

\subsubsection{Antibióticos solúveis}

Os antibióticos utilizados foram: penicilina $\mathrm{G}$, ampicilina, canamicina, neomicina, tetraciclina e estreptomicima.

Na Tabela 3 estão os antibióticos na forma de sais com seus respectivos fabricantes e diluentes.

Tabela 3 - Antibióticos e seus respectivos fabricantes e diluentes

\begin{tabular}{lll}
\hline Antibiótico & Fabricante & Diluente \\
\hline \hline Penicilina & SIGMA & Água \\
Ampicilina & SIGMA & Água \\
Estreptomicina & SIGMA & Água \\
Neomicina & SIGMA & Água \\
Tetraciclina & SIGMA & Etanol \\
Canamicina & Amersham Life Science USB & Água \\
\hline
\end{tabular}




\subsection{Isolamento bacteriano}

$\mathrm{O}$ isolamento foi realizado a partir de folhas, ramos e pecíolos de citros. Após a chegada do material ao laboratório o isolamento foi realizado no máximo após 48 horas, permanecendo o material vegetal estocado à $4{ }^{\circ} \mathrm{C}$.

Foram utilizadas duas técnicas de isolamento, uma para isolamento nos ramos e outra para isolamento no pecíolos, nervuras centrais e ramos finos.

\subsubsection{Isolamento nos ramos (Uchibaba 1992)}

Para isolamento da bactéria, os ramos foram lavados em água corrente, cortados em secções de $0,5-1 \mathrm{~cm}$ de diâmetro e $5-10 \mathrm{~cm}$ de comprimento e desinfectados superficialmente através da imersão em álcool $70 \%$ por 3 minutos, e em seguida flambado. As seções foram cortadas assepticamente e espremidas com o auxílio de um

alicate. A seiva foi depositada sobre o meio de cultura BCYE através do toque da superficie do meio com a extremidade da seção. As placas foram incubadas à $28^{\circ} \mathrm{C}$ e observadas periodicamente com o auxílio de lupa com aumento de $25 \mathrm{x}$, por até 30 dias, para a verificação das colônias de $X$ fastidiosa.

\subsubsection{Isolamento no pecíolo, nervura central e ramos finos (Lima, 1998)}

Folhas, pecíolo e ramos finos foram lavados em água corrente e em seguida passaram por uma desinfecção superficial consistindo de 1 minuto. em etanol 70\%, 3 minutos em hipoclorito $1 \%$ e lavado por 5 minutos em água destilada esterilizada. Após a esterilização o pecíolos e nervura foram cortados em pedaços de aproximadamente $\leq 2$ $\mathrm{cm}$, e os ramos em pedaços de $0,5 \mathrm{~cm}$ de forma asséptica, e transferidos para tubos Falcon de $15 \mathrm{ml}$, adicionado de $2 \mathrm{ml}$ de meio PW líquido e centrifugado a $9700 \mathrm{~g}$ por 10 minutos, para a liberação do conteúdo xilemático. Em seguida alíquotas do sobrenadante, de $1 \mathrm{~mL}$, foram inoculadas em meio PW líquido, após diluição apropriada e incubado à 
$28^{\circ} \mathrm{C}$.. Após 15 a 20 dias de incubação, os tubos com aparente crescimento bacteriano foram separados e plaqueados em meio PW sólido.

\subsection{Identificação dos isolados de $X$. fastidiosa}

A identificação de $X$. fastidiosa foi baseada no seu crescimento lento, características culturais das colônias, reação negativa ao teste de Gram, tamanho e características da célula bacteriana em exame microscópico e por PCR, com os "primers" CVC-1 e 272-int. (Pooler \& Hartung, 1995) específicos para a X. fastidiosa causadora da CVC. Os isolados foram estocados em $-80^{\circ} \mathrm{C}$ em PW líquido acrescido de glicerol(40\% concentração final).

\subsubsection{Características culturais}

\subsubsection{Colônia de X. fastidiosa}

A morfologia das colônias foram verificadas após crescimento em meio PW sólido onde se observou a forma, pigmentação e consistência.

\subsubsection{Coloração de Gram}

Lâminas com esfregaço bacteriano de $X$. fastidiosa foram secadas levemente para fixar. Em seguida foi tratado como a seguir:

- corado em solução de cristal violeta por 1 minuto,

- corado em solução lugol por 1 minuto e lavado em solução de etanol : acetona,

- corado em solução de safranina por 30 segundos, lavado em água corrente e secado em papel absorvente. 


\subsubsection{PCR para identificação de $X$. fastidiosa}

Após a identificação por características culturais, de coloração de Gram e observação em microscópio óptico, as culturas foram submetidas a diagnóstico pela técnica de PCR.

Foram utilizados os pares de "primers" 272-1 e 272-2 e CVC-1 e 272-2 int (Pooler \& Hartung, 1995a) e o DNA utilizado para a reação foi retirado diretamente de culturas líquidas ou de colônias isoladas sem extração prévia.

A região do DNA amplificado pela da técnica de PCR ocorreu em termociclador Perkin-Elmer-Cetus, programado para realizar uma desnaturação inicial por 5 minutos a $94{ }^{\circ} \mathrm{C}$, seguida de 30 ciclos de 1 minuto a $94{ }^{\circ} \mathrm{C} ; 1$ minuto a $62{ }^{\circ} \mathrm{C} ; 2$ minutos a $72{ }^{\circ} \mathrm{C}$, e após os ciclos uma extensão final de 4 minutos a $72^{\circ} \mathrm{C}$.

O fragmento de DNA amplificado foi separado por eletroforese em gel de agarose $1,4 \%$ a 3 volts $/ \mathrm{cm}$, juntamente com o marcador de peso molecular DNA Ladder. Após a eletroforese, o gel foi corado em solução de brometo de etídio $(1,0 \mu \mathrm{g} / \mathrm{mL})$ e fotodocumentado.

\subsection{Extração de DNA genômico total (modidificado, Ausubel et al., 1992)}

Os isolados de $X$. fastidiosa foram inoculados em $5 \mathrm{~mL}$ de $\mathrm{PW}$ líquido e incubados por 15 dias a $28{ }^{\circ} \mathrm{C}$, após esse período aliquotas de $0,1 \mathrm{~mL}$ da cultura foram semeadas em meio PW sólido e incubado por até 20 dias.

Após crescimento característico de $X$. fastidiosa em placa de Petri, e realização de PCR, as colônias eram imersas em 2-3 mL de água destilada esterilizada, com posterior desagregação por alça de vidro.

A suspensão bacteriana formada foi recolhida em tubos Falcon de $50 \mathrm{~mL}$ e centrifugada por 10 minutos a $9700 \mathrm{~g}$, com descarte do sobrenadante.

O pelete formado foi ressuspenso em $567 \mu$ de TE, adicionado $30 \mu$ de SDS e 3 $\mu l$ de proteinase $\mathrm{K}$. Misturado e incubado a $37{ }^{\circ} \mathrm{C}$ durante 1 hora. 
Após a incubação adicionou-se $100 \mu \mathrm{l}$ de $\mathrm{NaCl} 5 \mathrm{M}$ e homogenizou-se a suspensão. Em seguida, adicionou-se $80 \mu \mathrm{l}$ de CTAB 10\%, homogeneizando-se e incubando-se a $65^{\circ} \mathrm{C}$ durante 10 minutos a suspensão.

A esta suspensão adicionou-se 700 a $800 \mu \mathrm{l}$ de clorofórmio/álcool isoamílico, homogenizando-se pela inversão dos tubos por 80 vezes e posteriormente centrifugado a $9700 \mathrm{~g} 10$ minutos.

Remoção da fase superior para um novo tubo, evitando-se tocar na interface. $\mathrm{O}$ conteúdo do novo tubo acrescido de $5 \mu$ de RNAse foi incubado por 30 minutos a $37^{\circ} \mathrm{C}$. Com posterior homogeneização vigorosa e centrifugação a $9700 \mathrm{~g}$ durante 10 minutos.

Após a centrifugação foi transferido o sobrenadante para um novo tubo, adicionando-se 0,6 volumes de isopropanol ou 2 volumes de etanol $100 \%$, o qual foi homogeneizado por inversões do tubo. Acondicionado em seguida por 2 horas a $-20{ }^{\circ} \mathrm{C}$ ou 20 minutos a $-80^{\circ} \mathrm{C}$. Posteriormente centrifugou-se a 9700 g por 5 minutos em temperatura ambiente.

Descartado o sobrenadante e lavado o pelete de DNA com $600 \mu \mathrm{l}$ de etanol 70 $\%$, centrifugou-se a $14000 \mathrm{rpm}$ por 5 minutos em temperatura ambiente.

Removido o sobrenadante o pelete foi seco a $37^{\circ} \mathrm{C}$.

Finalmente o DNA extraido foi ressuspenso em $50 \mu 1$ de TE e estocado a $-20^{\circ} \mathrm{C}$.

\subsection{Análise de polimorfismo gerado por marcadores de RAPD}

\subsubsection{Amplificação do DNA genômico}

Regiões do DNA genômico foram amplificadas através da técnica de RAPD, em termociclador Perkin-Elmer-Cetus, programado para realizar uma desnaturação inicial 4 minutos a $92^{\circ} \mathrm{C}$, seguida de 40 ciclos de 1 minuto a $92^{\circ} \mathrm{C}, 2$ minutos a $37^{\circ} \mathrm{C}, 3$ minutos a $72^{\circ} \mathrm{C}$, e após os ciclos uma extensão final de 3 minutos a $72^{\circ} \mathrm{C}$. 
Os fragmentos amplificados foram separados por eletroforese em gel de agarose $1,4 \%$ a 3 volt $/ \mathrm{cm}$, juntamente com o marcador de peso molecular DNA Ladder. Após a eletroforese o gel foi corado em solução de brometo de etídio e fotodocumentado.

\subsection{2. "Primers" selecionados}

Os "primers" utilizados foram produzidos pela Operon Technologies (Alabama, CA, EUA) e apresentam seqüência de nucleotídeos e peso molecular listados na tabela 4.

Tabela 4 - Lista de "primers" selecionados para o RAPD

\begin{tabular}{ccc}
\hline "Primers" & Seqüência 5’ $\rightarrow$ 3' & Conteúdo de bases GC (\%) \\
\hline OPP -6 & GTGGGCTGAC & 70 \\
OPP -9 & GTGGTCCGCA & 70 \\
OPAX -5 & AGTGCACACC & 60 \\
OPAX -12 & GGTCGGGTCA & 70 \\
OPAX -18 & GTGTGCAGTG & 60 \\
OPX -1 & CTGGGCACGA & 70 \\
OPX -4 & CCGCTACCGA & 70 \\
\hline
\end{tabular}

\subsubsection{Construção do dendograma}

Os dados obtidos por amplificação ao acaso do DNA genômico (RAPD) foram transformados em variáveis binárias, ou seja, o número 1 significou presença de banda e o número 0 a ausência de banda, e desta forma foram introduzidos no programa NTSYSPC (Applied Biostatistics, Inc.). Este programa produziu o coeficiente de similaridade de JACCARD. Os dados da matriz de similaridade, foram então utilizados pelo programa para a construção do dendograma pelo método de UPGMA. Este dendograma agrupou os diferentes isolados mostrando o nível de similaridade genética entre os isolados bacterianos. A porcentagem de vezes que ocorreu agrupamento na análise de "bootstrap" foi obtida utilizando o "software" "Winboot" (Yap \& Nelson). 


\subsection{Teste de sensibilidade à antibióticos}

\subsubsection{Antibiograma pelo método de difusão}

Foram utilizados discos de antibióticos, com concentrações já pré-determinadas para a realização do antibiograma.

Colocou-se 20 ml de ágar PW em placa de Petri, após sua solidificação espalhouse sobre o meio $100 \mu \mathrm{l}$ de uma suspensão bacteriana $\left(10^{9}\right)$ ressuspensa em caldo PW. Após 2 horas foram colocados os discos de antibiótico sobre o meio e prensados com uma pinça. As observações das culturas foram realizadas a partir do $3^{\circ}$ até o $30^{\circ}$ dia de incubação a $28{ }^{\circ} \mathrm{C}$. Este experimento foi conduzido com no mínimo três repetições para cada isolado testado.

\subsubsection{Antibiograma pelo método das diluições em meio líquido}

As soluções estoques das drogas foram preparadas nos diluentes recomendados, esterilizadas por filtração em filtro Millipore com diâmetro 0,2 micrômetros $\mathrm{e}$ conservadas a $-20^{\circ} \mathrm{C}$, com exceção da tetraciclina, que foi mantida a $4^{\circ} \mathrm{C}$, até o momento do uso.

Os níveis de resistência foram determinados pela técnica de diluição em meio líquido. No preparo dos tubos usou-se o caldo $\mathrm{PW}$, sendo colocado em cada tubo $5 \mathrm{ml}$ do meio de cultura e deixados de "quarentena" por 48 horas, aproximadamente, para deteç̧ão de contaminantes.

Após a "quarentena" quantidades adequadas de cada droga em solução, eram colocadas nos tubos de ensaio, obtendo-se concentrações finais de 1, 2, 5, 10, 20, 50, 100 e $200 \mu \mathrm{l}$ da droga por $\mathrm{ml}$ de meio de cultivo. Os tubos assim preparados eram imediatamente usados.

Na preparação do inóculo procedeu-se da seguinte forma: cada um dos isolados foram incubados a $28{ }^{\circ} \mathrm{C}$ em caldo $\mathrm{PW}$ por um período de 7 dias. 
Após esse período inoculou-se $100 \mu \mathrm{l}$ da cultura bacteriana, com cerca de $10^{9}$ bactérias $/ \mathrm{mL}$ em tubos contendo caldo $\mathrm{PW}$, com as respectivas concentrações do antibiótico, e em mais dois tubos isentos de antibióticos, considerado tempo zero da inoculação e o branco do teste. O tubo denominado de tempo zero era imediatamente congelado após a inoculação da bactéria, enquanto o controle (sem antibiótico) e os demais com as diferentes concentrações dos antibióticos foram incubados à $28^{\circ} \mathrm{C}$.

A partir do $3^{\circ}$ dia foram feitas observações periódicas nos tubos até o $15^{\circ}$ dia de incubação, após esse periodo foram feitas leituras no espectrofotometro na faixa do 600 $\eta m$ de comprimento (Hopkins, 1984).

Para se fazer a leitura procedeu-se da seguinte forma: transferiu-se um volume de $600 \mu \mathrm{L}$ de cada tubo inoculado e contendo as respectivas concentrações de cada antibiótico para uma 'eppendorf de $2 \mathrm{ml}$ e completou-se com água destilada e esterilizada para um volume de $1200 \mu \mathrm{L}$, em seguida centrifugou-se por 10 minutos a $9700 \mathrm{~g}$ a temperatura ambiente. Imediatamente após a centrifugação retirou-se um volume de $600 \mu \mathrm{L}$ do sobrenadante para ser utilizado como o branco de calibração no espectrofotometro e o restante do volume $(600 \mu 1)$ foi ressuspendido vigorosamente $\mathrm{e}$ transferido para a cubeta de leitura e, também, imediatamente fez-se a leitura, antes que as células de $X$. fastidiosa precipitassem. Essa mesma metodologia foi utilizada para o tubo controle e o tubo denominado tempo zero.

\subsection{Metodologia de interação "in vitro" entre microrganismos endofíticos de citros e $X$. fastidiosa}

Os microrganismos endofiticos utilizados nestes trabalho foram estriados em placas com meio PW e incubados a $28^{\circ} \mathrm{C}$ por 24 horas. Após este período de incubação para bactérias endofiticas inoculou-se isolados de $X$. fastidiosa, estriando-as transversalmente aos endofiticos. Incubou-se novamente à $28^{\circ} \mathrm{C}$ por mais 20 a 30 dias. 


\section{RESULTADOS}

\subsection{Isolamento e cultivo de $X$. fastidiosa de plantas cítricas}

Para isolamento primário da $X$. fastidiosa de plantas cítricas optou-se pelo método proposto por Lima et al. (1998), levando-se em consideração o tempo de incubação para o aparecimento de colônias, onde o crescimento bacteriano ocorria no intervalo de 7 a 10 dias, consequentemente seguido de maior número de colônias. Para o método proposto por Uchibaba et al. (1992) os fatores acima mencionados deixavam a desejar, pois o tempo de incubação era maior, cerca de 20 a 30 dias, com aparecimento de colônias pequenas e em número reduzido. Fatos comprovados num exame preliminar para escolha da metodologia de isolamento desta bactéria.

Para cultivo em meio sólido, comparados os meios BCYE e PW, propostos respectivamente por Wells et al. (1981) e Davis et al. (1981), constatou-se que o BCYE apesar de evidenciar um crescimento lento resultava numa maior concentração de massa bacteriana, quando as inoculações eram feitas por estrias.

Para manutenção das culturas, extração de DNA genômico e realização dos antibiogramas em meio sólido e líquido optou-se pelo meio PW, considerando-se o tempo menor para o crescimento da bactéria.

Outros aspectos que devem ser registrado são: a presença do soro albumina bovina (BSA) no meio PW não inibiu a ação dos antibióticos. No cultivo da bactéria neste meio foi indiferente a troca do soro albumina bovina pelo carvão ativado com a vantagem de melhorar a visualização das colônias. 


\subsection{Identificação dos isolados de $X$. fastidiosa}

Foram obtidos um total de 15 isolados de $X$. fastidiosa provenientes de diferentes regiões do estado de São Paulo, sendo estes utilizados para a realização do RAPD, juntamente com o isolado referência, dois isolados do cafeeiro e videira. (Tabela 5).

Tabela 5. - Isolados de $X$. fastidiosa por hospedeiro e região

\begin{tabular}{|c|c|c|}
\hline Isolados & Hospedeiro & Região \\
\hline $9 a 5 c$ & Citrus sinensis & Macaubal \\
\hline 3 & Citrus sinensis & Araraquara \\
\hline 4 & Citrus sinensis & Araraquara \\
\hline 5 & Citrus sinensis & Taquaritinga \\
\hline 6 & Citrus sinensis & Matão \\
\hline 7 & Citrus sinensis & Bebedouro \\
\hline 8 & Citrus sinensis & Matão \\
\hline 9 & Citrus sinensis & Olímpia \\
\hline 10 & Citrus sinensis & Colina \\
\hline 11 & Citrus sinensis & Itapetininga \\
\hline 12 & Citrus sinensis & Itápolis \\
\hline 13 & Citrus sinensis & Macaubal \\
\hline 14 & Citrus sinensis & José Bonifácio \\
\hline 15 & Citrus sinensis & Macaubal \\
\hline 16 & Citrus sinensis & Curupá \\
\hline 17 & Vittis vinifera & EUA \\
\hline 18 & Coffea arabica & S. J. do Rio Preto \\
\hline 19 & Coffea arabica & Marília \\
\hline 20 & Citrus sinensis & Novaes \\
\hline
\end{tabular}


Os isolados foram identificados por características culturais, método de coloração de Gram e por PCR, monitorados durante todo o trabalho por essa última técnica.

Para PCR, utilizando os "primers" que amplificam banda de $X$. fastidiosa de qualquer hospedeiro (272-2 e 272-1), constatou-se amplificação em todos os isolados. (Figura 1).

Quando no PCR foram utilizados "primers" específicos para amplificação da banda de $X$. fastidiosa de citros (CVC-1 e 272-int.), houve amplificação para todos os isolados de citros, linhagem referência e para as linhagens isoladas do cafeeiro. Não ocorrendo amplificação para o isolado de videira (Figura 2).

\subsection{Análise de variabilidade genética por RAPD}

\subsubsection{Padronização da técnica de RAPD}

Para a padronização da reação de RAPD, foi escolhido o DNA de dois isolados, um confirmadamente causador da CVC, oriundo da região de Araraquara, com os "primers" CVC-1 e 272-2 int e o isolado referência 9a5c. Esses isolados foram submetidos a ensaios de concentração de DNA e $\mathrm{MgCl}_{2}$, e após esta padronização foi feita a escolha dos "primers" capazes de amplificar o DNA genômico dos isolados $X$. fastidiosa.

O padrão de bandas obtidos para ajuste da concentração de DNA e $\mathrm{MgCl}_{2}$, utilizando o isolado 12 e marcador de $1 \mathrm{~kb}(\mathrm{M})$, variando a concentração de DNA em 20

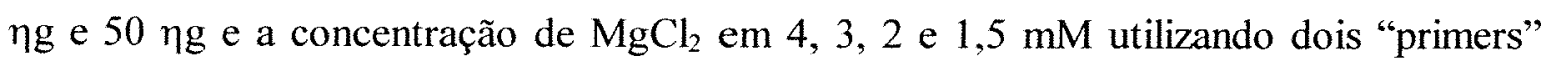
pode ser observado na Figura 3.

As melhores condições para o ajuste da concentração de DNA e $\mathrm{MgCl}_{2}$ foram de $20 \eta \mathrm{g}$ de DNA e $3 \mathrm{mM}$ para os dois "primers" testados onde se obteve bandas mais claras e nítidas. 


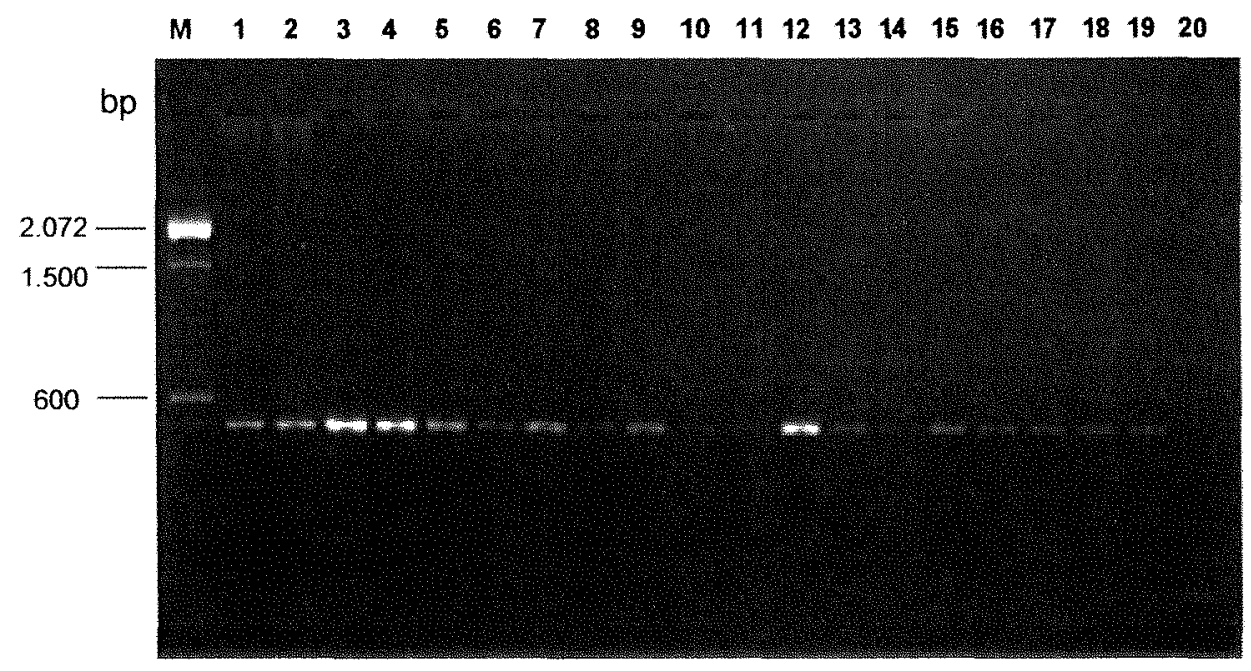

Figura 1. - Padrão de bandas obtido por PCR, utilizando os "primers" CVC-1 e 272-2 int. para isolados de $X$. fastidiosa obtidos de citros $(1,2,3,4,5,6,7,8,9,10$, $11,12,13,14,15,16,17)$, cafeeiro $(18,19)$ e videira $(20)$

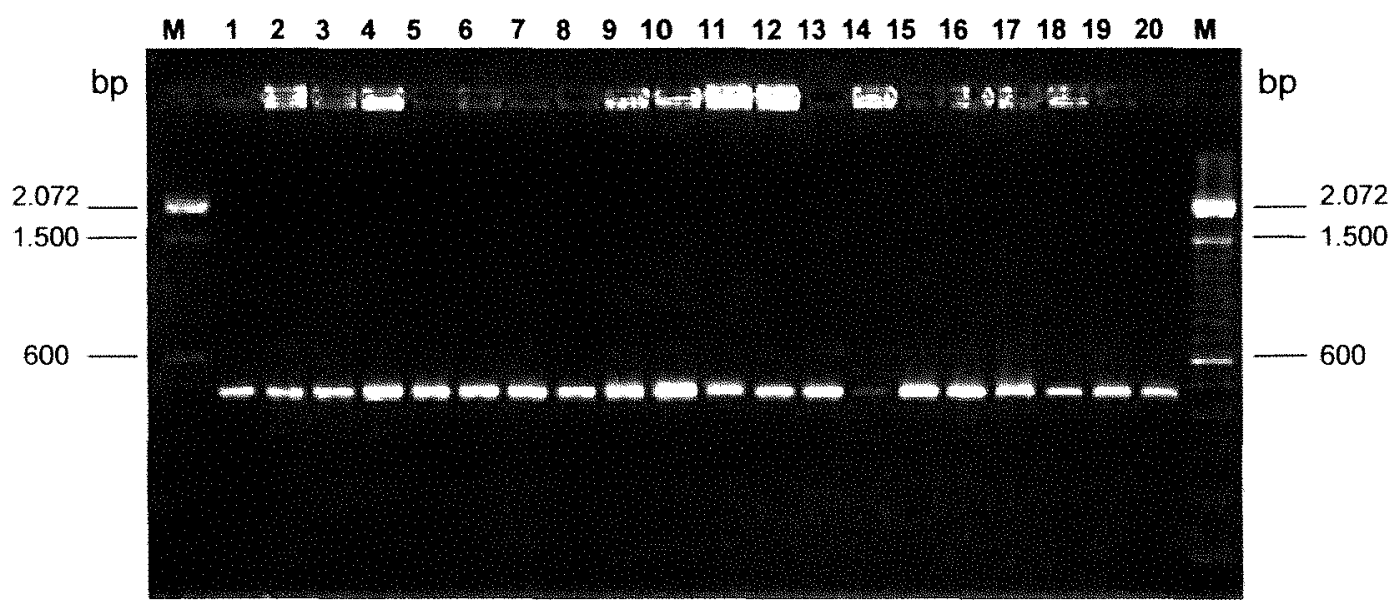

Figura 2. - Padrão de bandas obtido por PCR, utilizando os "primers" 272-2 e 2721. para isolados de $X$. fastidiosa obtidos de citros $(1,2,3,4,5,6,7,8,9,10,11,12$, $13,14,15,16,17)$, cafeeiro $(18,19)$ e videira $(20)$ 


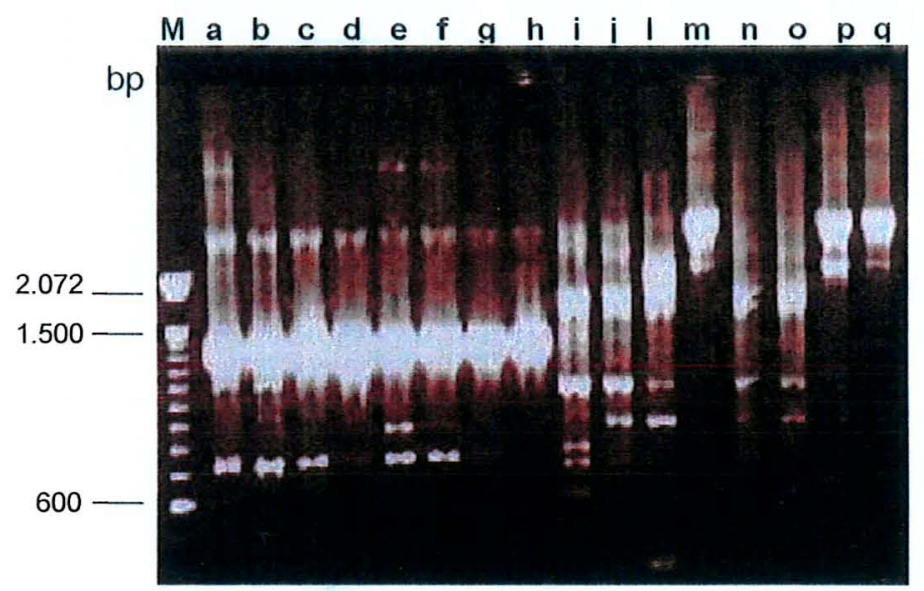

Figura 3. - Padrão de bandas obtido para ajuste da concentração de $\mathrm{DNA}$ e $\mathrm{MgCl}_{2}$, utilizando o isolado de citros de Araraquara e marcador de 100 bp, Gibco-BRL, (M), variando a concentração de DNA em 20 ng (a, b, c, d, i, j, l, m) e 50 ng (e, f, g, h, n, o, p, q) e a concentração de $\mathrm{MgCl}_{2}$ em 4 (a, e, i, n), 3 (b, f, j, o) 2 (c, g, l, p) e 1,5 mM (d, h, m, q) utilizando os "primers" OPAX05 (a, b, c, d, e, f, g, h) e OPX06 $(\mathbf{i}, \mathbf{j}, \mathbf{l}, \mathbf{m}, \mathbf{n}, \mathbf{o}, \mathbf{p}, \mathbf{q})$ 


\subsubsection{Escolha dos "primers"}

Após a padronização das condições de RAPD, partiu-se para a escolha dos melhores "primers", os quais deveriam produzir bandas fortes e bem definidas que permitissem posteriormente a visualização de polimorfismo entre os isolados estudados.

Com essa finalidade, foram ensaiados 13 "primers" do KIT OPP, 12 do OPAX e 10 do OPX, e destes foram escolhidos 7 "primers" para a realização do RAPD. (Tabela 4).

\subsubsection{Verificação de polimorfismo por RAPD}

Para a verificação da variabilidade existente entre os isolados bacterianos estudados, foi extraído DNA dos 15 isolados de $X$. fastidiosa causadora da CVC (Tabela 5), sendo incluído na extração o isolado referência, e os isolados de cafeeiro e de videira.

Estes DNAs foram amplificados com os "primers" selecionados, permitindo por meio de marcadores de RAPD verificar suas relações genéticas.

A análise conjunta dos 6 "primers" permitiu a construção de uma matriz de similaridade, por meio do coeficiente de JACCARD, e posteriormente a elaboração de um dendograma a partir desta matriz, através do método de UPGMA (Figura 4).

Os padrões de bandas obtidos com o primer OPX06 podem ser observado na Figura 5. 
* Identificação dos isolados de X. fastidiosa

\begin{tabular}{|c|c|c|}
\hline Isolados & Hospedeiro & Regiño \\
\hline $9 a 5 c$ & Citrus sintensis & Macaubal \\
\hline 3 & Citrus sinensis & Araraqura \\
\hline 4 & Citrus sinensis & Araraquara \\
\hline 5 & Citrus sinensis & Taquaritinga \\
\hline 6 & Citrus sinensis & Matão \\
\hline 7 & Cirrus sinensis & Bebedouro \\
\hline 8 & Citrus sinensis & Matão \\
\hline 9 & Citrus sinensis & Olímpia \\
\hline 10 & Citrus sinensis & Colina \\
\hline 11 & Cürus sinensis & Itapetininga \\
\hline 12 & Citrus sinensis & Itápolis \\
\hline 13 & Citrtus sinensis & Macaubal \\
\hline 14 & Citrus sinensis & José bonifácio \\
\hline 15 & Citrus sinensis & Macaubal \\
\hline 16 & Citrus sinensis & Curupá \\
\hline 17 & Iütis vinifera & USA \\
\hline 18 & Coffea arabica & S.J. do Rlo Preto \\
\hline 19 & Coffea arabica & Marilia \\
\hline 20 & Cirrus sinensis & Novaes \\
\hline
\end{tabular}

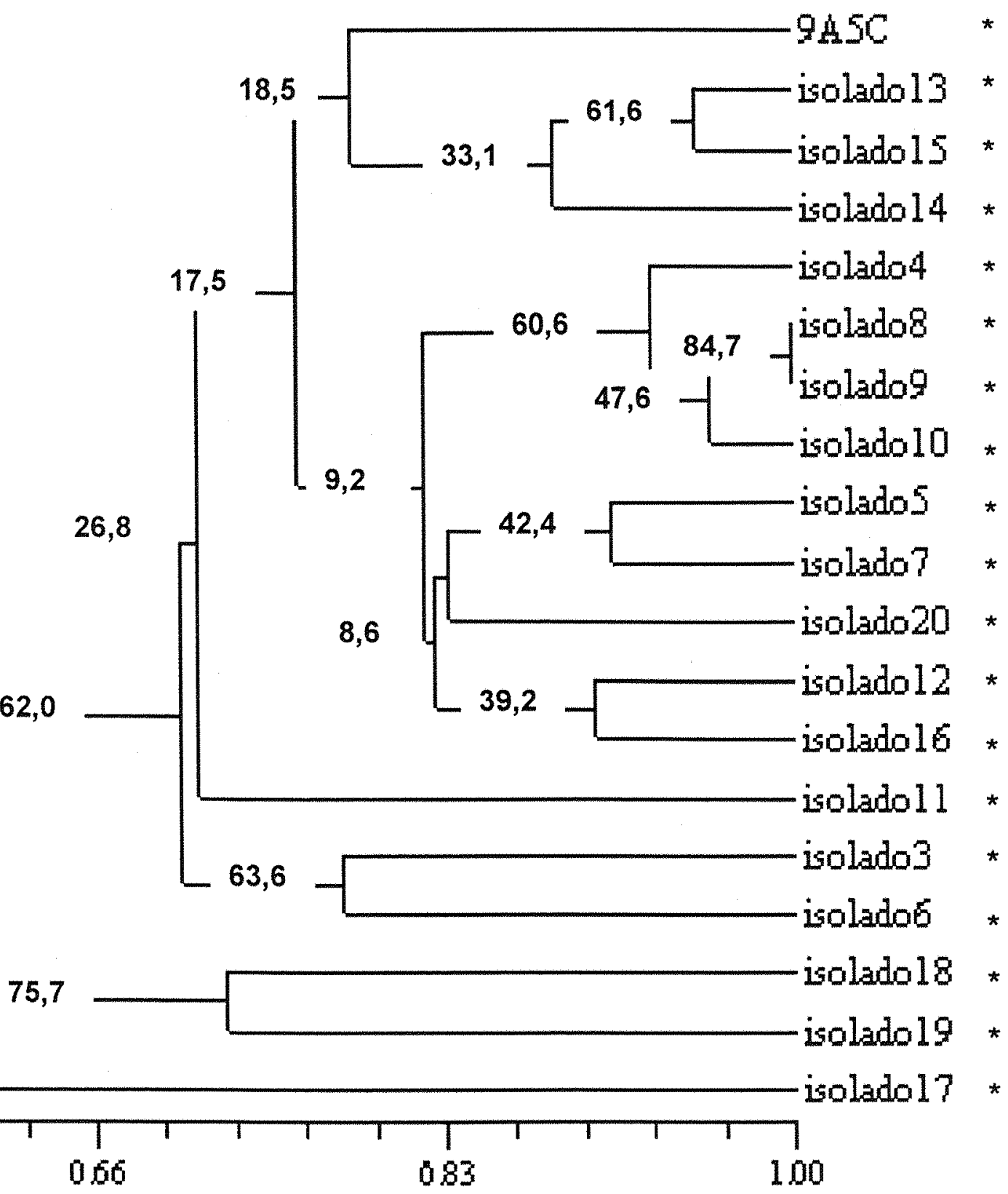

Figura 4. - Dendograma obtido a partir de uma matriz de similaridade genética entre os isolados de $X$. fastidiosa de citros, cafeeiro e videira. 


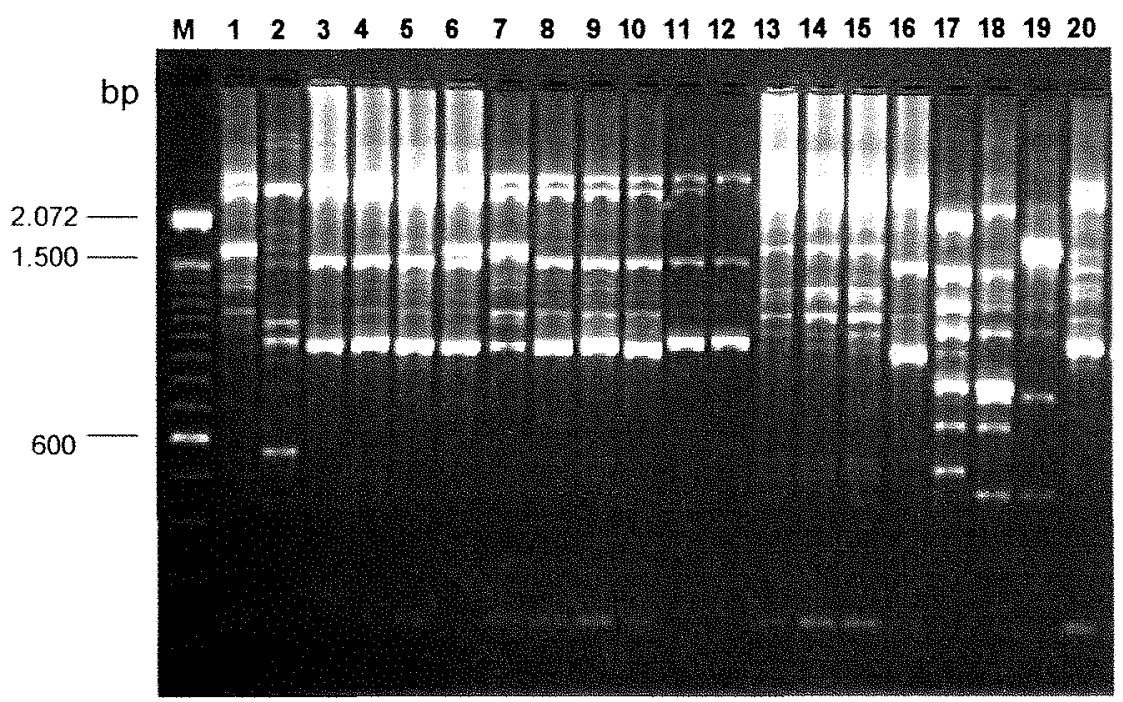

Figura 5. - Perfil eletroforético obtido com o "primer" OPP06 para X fastidiosa com os isolados $1(9 \mathrm{a} 5 \mathrm{c}), 2,3,4,5,6,7,8,9,10,11,12,13,14,15,16,20$ para citros, 17, 18 para cafeeiro e 19 para videira

\subsection{Antibiograma pelo método de difusão}

Todos os isolados foram sensiveis aos antibióticos canamicina, neomicina, polimixina, rifampicina, estreptomicina, ampicilina e cloranfenicol e resistentes a penicilina, segundo o método de Kirby-Bauer. Na Tabela 6 observa-se o tamanho dos halos de inibição e a sensibilidade bacteriana aos antibióticos

Com um período de 7 dias de cultivo observou-se a formação de halos de inibição por parte dos isolados, conforme observa-se na Figura 6. Após 20 a 30 dias de cultivo o meio altera a sua coloração em função da atividade alcalinizante da bactéria, acrescido de uma visualização maior das colônias, embora o tamanho do halo permaneça inalterado (Figura 7 e 8 ) 


\subsection{Antibiograma pelo método das diluições}

Foram utilizados 10 isolados para realização desta etapa do trabalho, sendo 7 de citros provenientes das seguintes regiões: Araraquara, Matão, Macaubal, Itapetininga Olímpia, Colina e Novaes, incluindo o isolado 9a5c (citros) e os isolado de cafeeiro e de videira, sendo testados os níveis de resistência para os antibióticos: estreptomicina, neomicina, tetraciclina, canamicina, ampicilina e penicilina.

A concentração mínima inibitória (MIC) foi determinada onde o antibiótico foi capaz de reduzir em $50 \%$ ou mais do crescimento bacteriano. Os resultados foram lançados na forma de gráficos, um para cada isolado com os respectivos antibióticos testados (Figuras 9 - 18). As concentrações mínimas inibitórias para os isolados testados pode ser observado na Tabela 7 . 
Tabela 6 - Diâmetro dos halos de inibição ( $\mathrm{mm})$ dos isolados de $X$. fastidiosa

\begin{tabular}{|c|c|c|c|c|c|c|c|c|c|c|}
\hline Antibióticos & Araraquara & Matão & Macaubal & Itapetininga & Olimpia & Colina & Novaes & Café & Videira & $9 \mathrm{a} 5 \mathrm{c}$ \\
\hline (30 mcg) & $\mathrm{S}^{*}$ & $\mathrm{~S}^{*}$ & $\mathrm{~S}^{*}$ & $\mathrm{~S}^{*}$ & $\mathrm{~S}^{*}$ & $\mathrm{~S}^{*}$ & $\mathrm{~S}^{*}$ & $\mathrm{~S}^{*}$ & $\mathrm{~S}^{*}$ & $\mathrm{~S}^{*}$ \\
\hline Polimixina $B$ & 20 & 22 & 20 & 22 & 20 & 22 & 25 & 25 & 29 & 20 \\
\hline$(30 \mathrm{mcg})$ & $S^{*}$ & $\mathrm{~S}^{*}$ & $\mathrm{~S}^{*}$ & $\mathrm{~S}^{*}$ & $\mathrm{~S}^{*}$ & $\mathrm{~S}^{*}$ & $\mathrm{~S}^{*}$ & $\mathrm{~S}^{*}$ & $\mathrm{~S}^{*}$ & $\mathrm{~S}^{*}$ \\
\hline Ampicilina & 20 & 20 & 18 & 20 & 22 & 23 & 19 & 21 & 20 & 15 \\
\hline$(10 \mathrm{mcg})$ & $\mathrm{S}^{*}$ & $\mathrm{~S}^{*}$ & $\mathrm{~S}^{*}$ & $\mathrm{~S}^{*}$ & $\mathrm{~S}^{*}$ & $\mathrm{~S}^{*}$ & $\mathrm{~S}^{*}$ & $\mathrm{~S}^{*}$ & $\mathrm{~S}^{*}$ & $\mathrm{~S}^{*}$ \\
\hline Vancomicina & 17 & 19 & 16 & 17 & 18 & 15 & 18 & 17 & 19 & 16 \\
\hline Penicilina $G$ & 10 & 8 & 5 & 4 & 7 & 6 & 9 & 9 & 6 & 4 \\
\hline$(10 \mathrm{mcg})$ & $\mathrm{R}^{* *}$ & $\mathrm{R}^{* *}$ & $\mathrm{R}^{* *}$ & $\mathrm{R}^{* *}$ & $\mathrm{R}^{* *}$ & $\mathrm{R}^{* *}$ & $\mathrm{R}^{* *}$ & $\mathrm{R}^{* *}$ & $\mathrm{R}^{* *}$ & $\mathrm{R}^{* *}$ \\
\hline Neomicina & 30 & 35 & 28 & 38 & 38 & 35 & 35 & 37 & 38 & 34 \\
\hline$(30 \mathrm{mcg})$ & $\mathrm{S}^{*}$ & $\mathrm{~S}^{*}$ & $\mathrm{~S}^{*}$ & $\mathrm{~S}^{*}$ & $\mathrm{~S}^{*}$ & $\mathrm{~S}^{*}$ & $\mathrm{~S}^{*}$ & $S^{*}$ & $\mathrm{~S}^{*}$ & $\mathrm{~S}^{*}$ \\
\hline
\end{tabular}

* Sensivel

** Resistente 


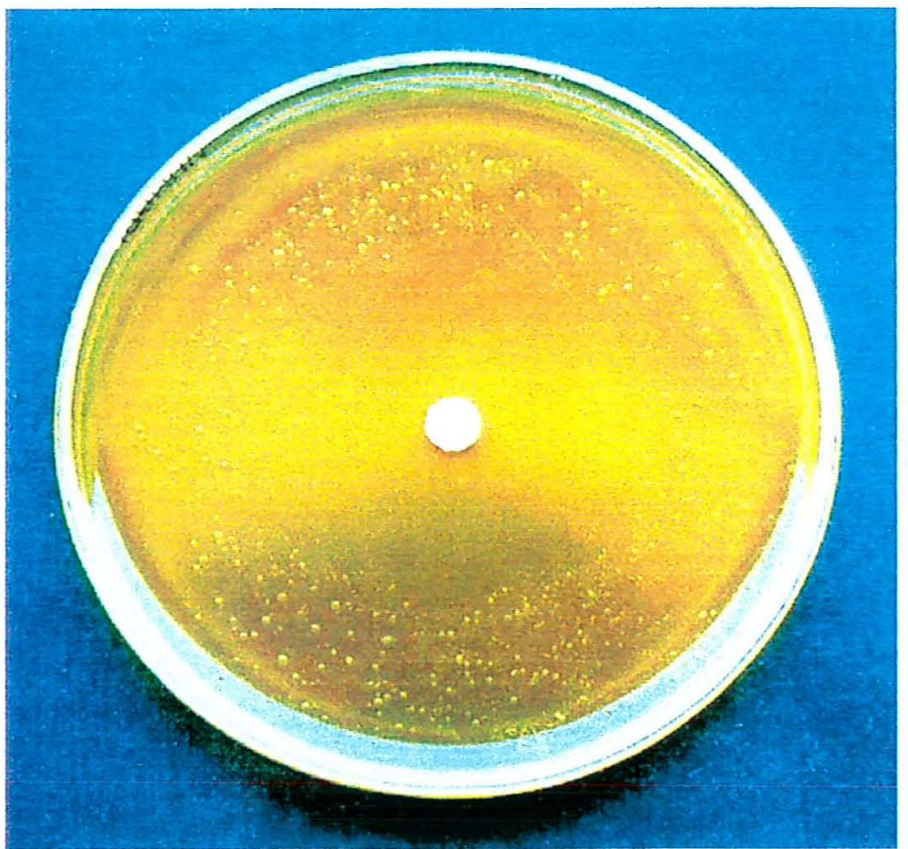

Figura 6. - Presença de halo de inibição de isolado de citros/região Araraquara frente ao antibiótico canamicina após 7 dias de cultivo

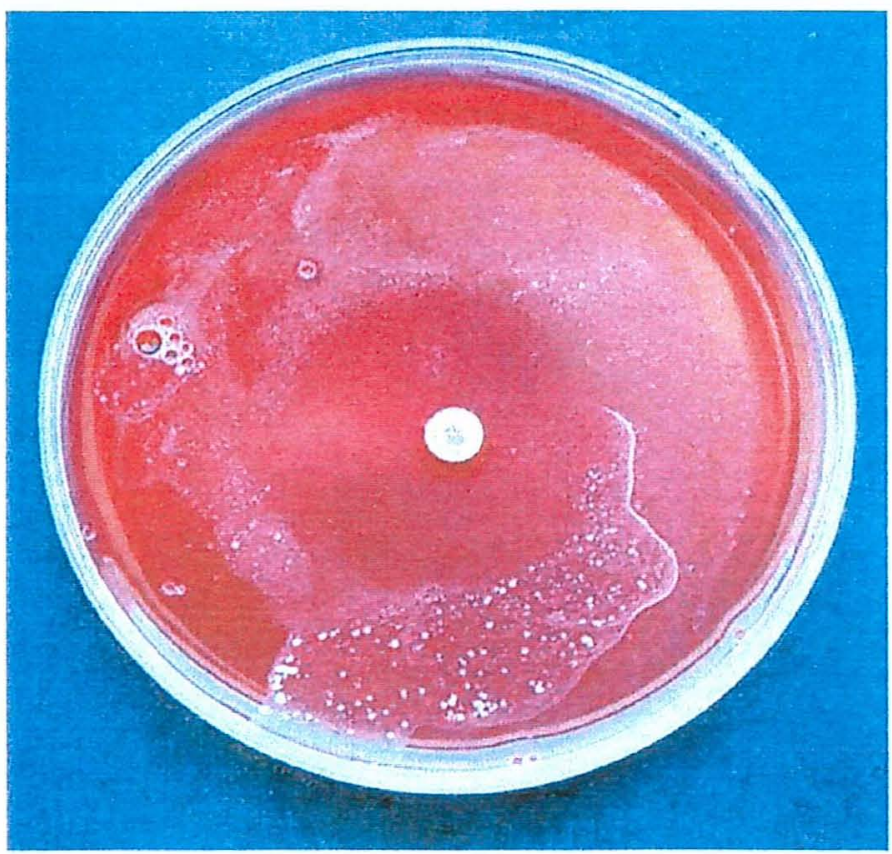

Figura 7. - Presença de halo de inibição do isolado 9a5c frente ao antibiótico vancomicina após 20 dias de cultivo 


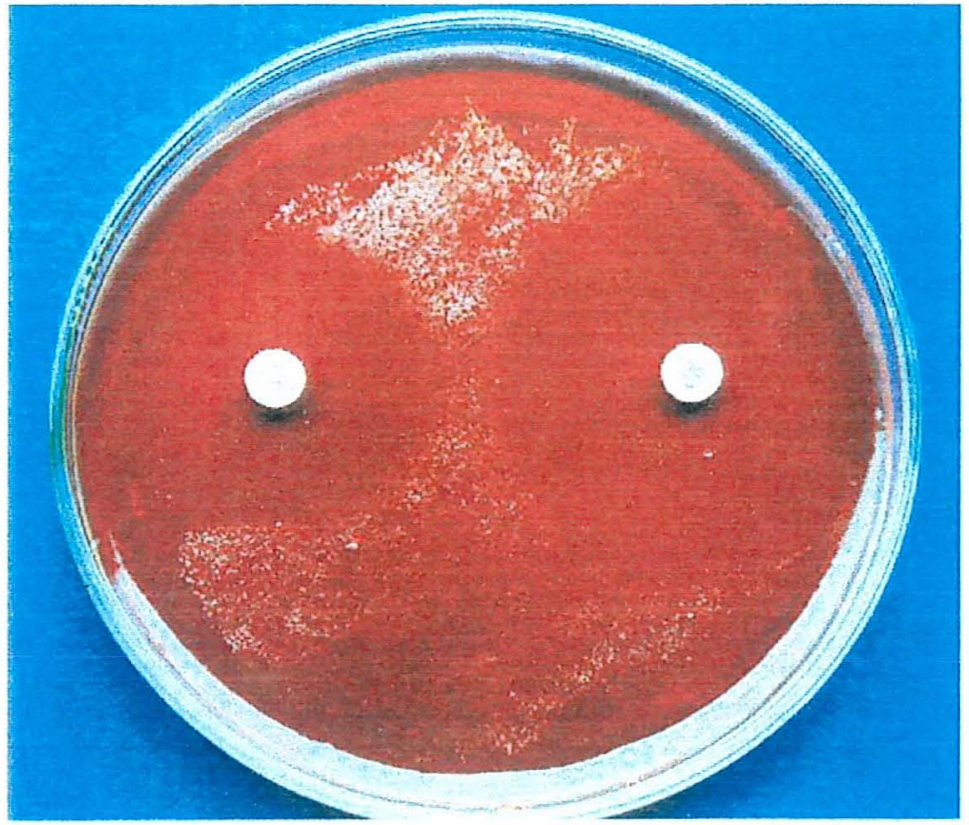

Figura 8. - Presença de halo de inibição do isolado de citros/região Matão frente aos antibióticos polimixina e neomicina após 30 dias de cultivo 
Tabela 7 - Concentração mínima inibitória dos antibióticos testados para os 8 isolados de citros, 1 isolados de cafeeiro e 1 isolado de videira

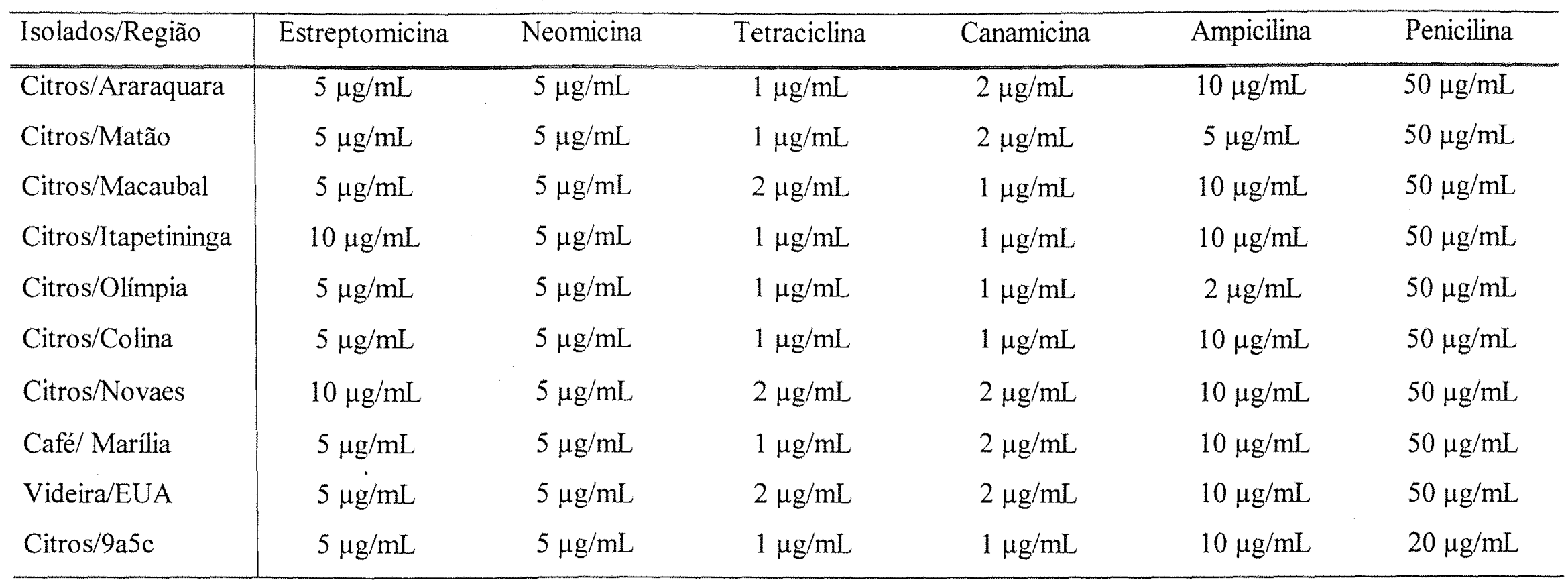


Isolado: Araraquara/citros
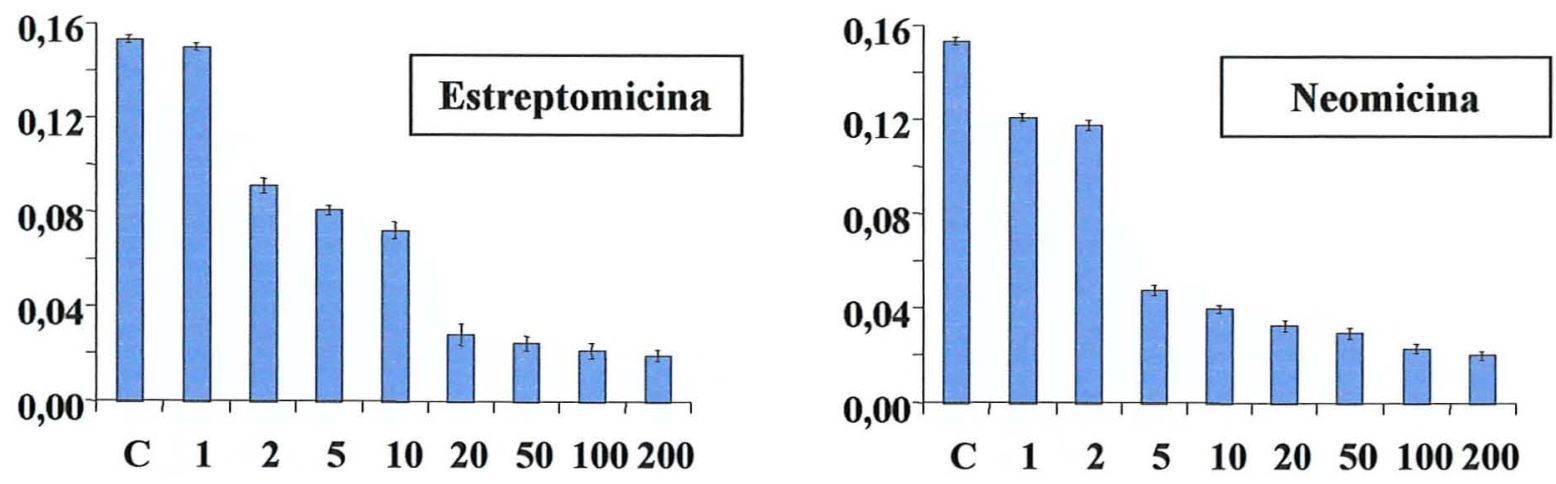

플
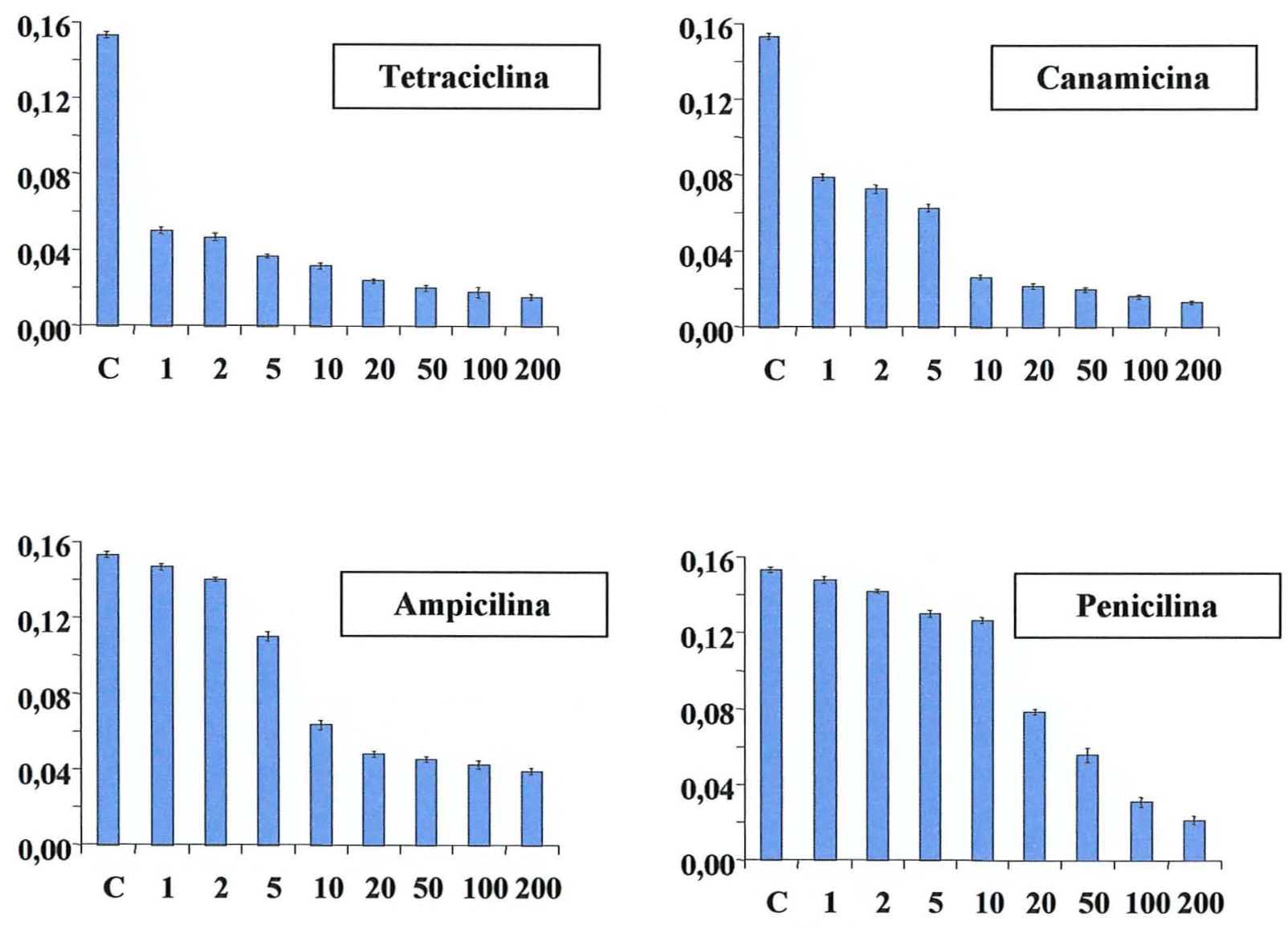

Concentração dos antibióticos $(\mu \mathrm{g} / \mathrm{mL})$

Figura 9. - Curvas de inibição do isolado de citros da região de Araraquara à diferentes concentrações de antibióticos 
Isolado: Matão/citros
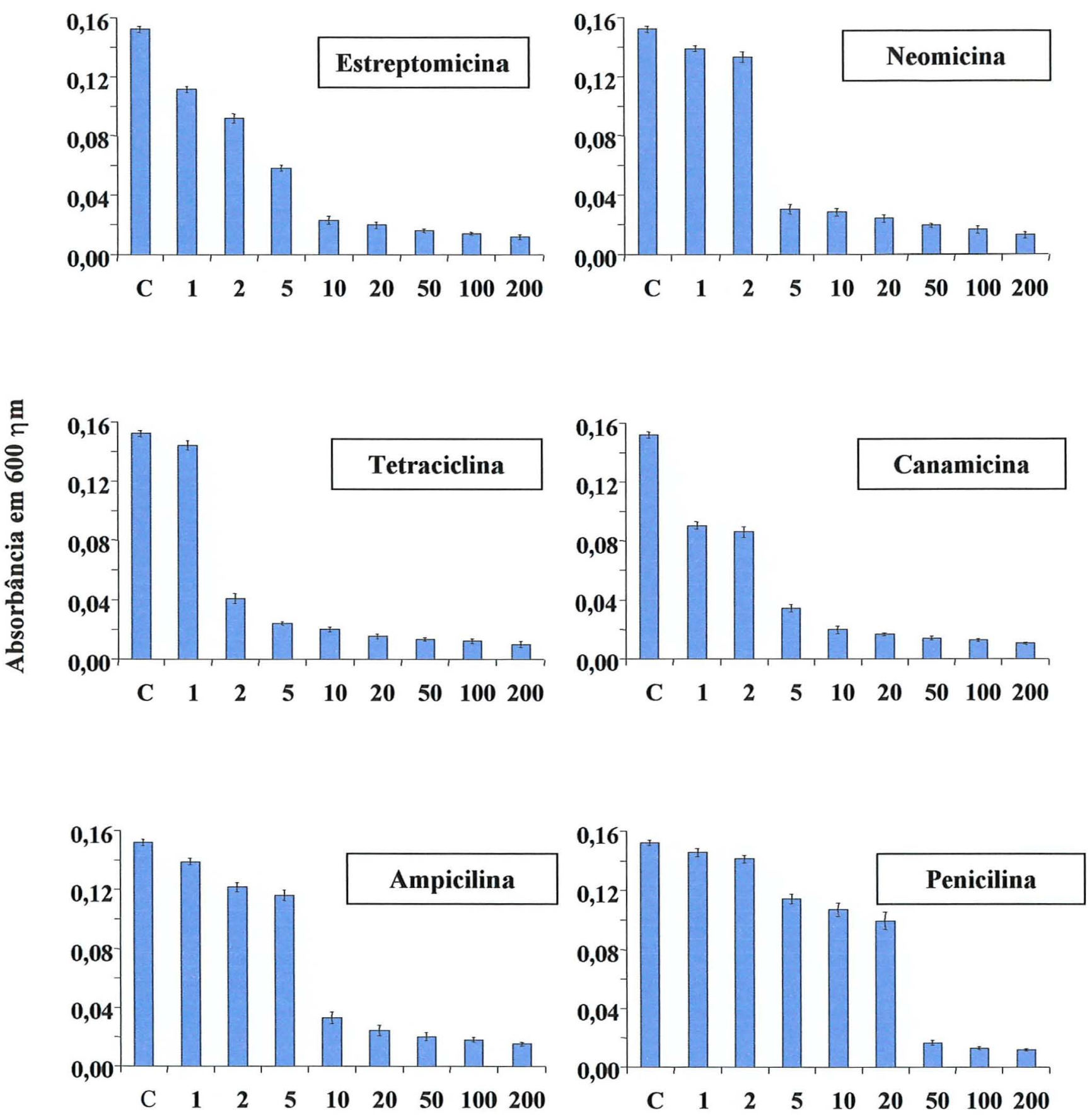

Concentração dos antibióticos $(\mu \mathrm{g} / \mathrm{mL})$

Figura 10. - Curvas de inibição do isolado de citros da região de Matão à diferente: concentrações de antibióticos 
Isolado:Macaubal/citros
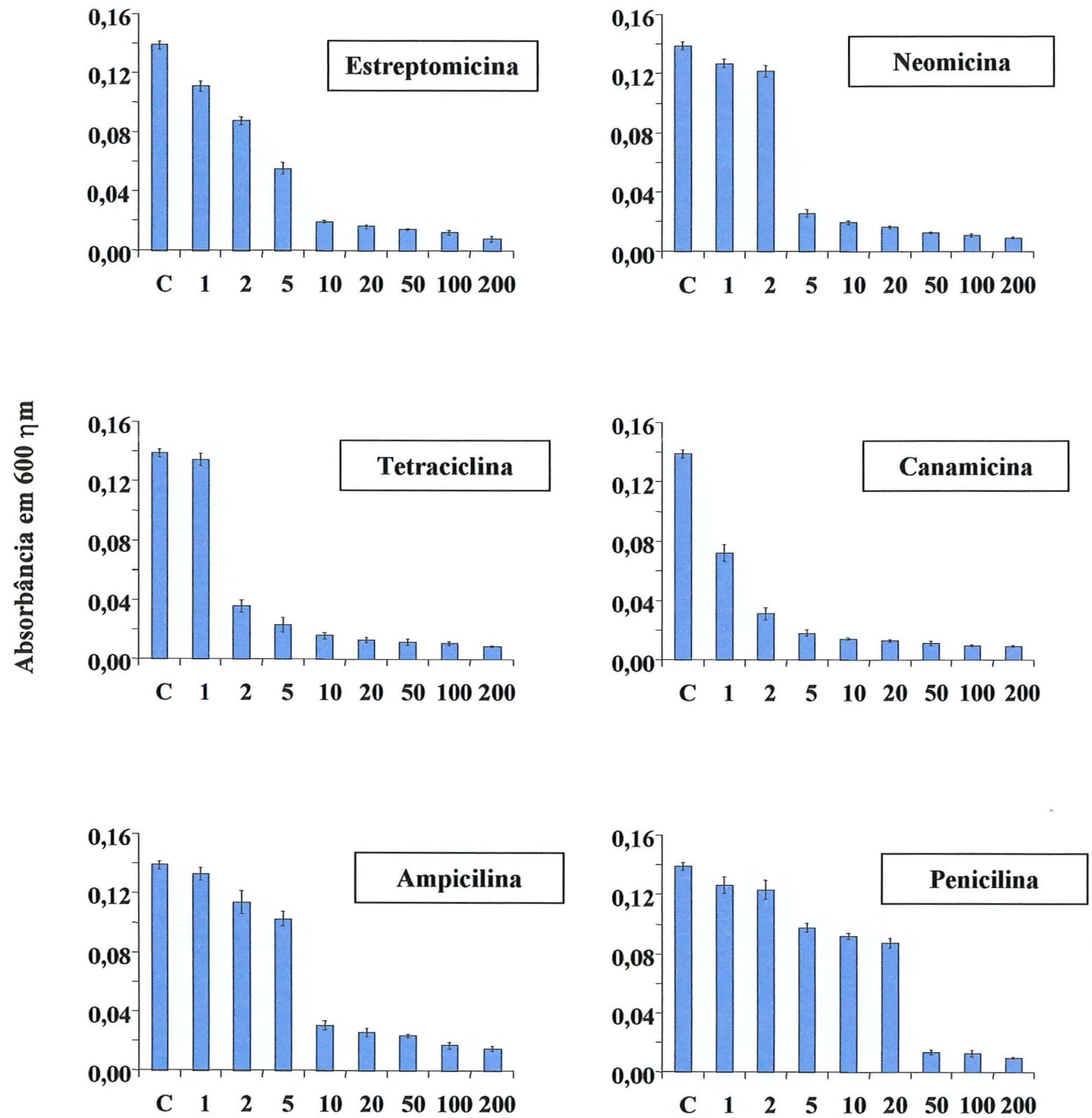

Concentração dos antibióticos $(\mu \mathrm{g} / \mathrm{mL})$

Figura 11. - Curvas de inibição do isolado de citros da região de Macaubal à diferentes concentrações de antibióticos 
Isolado: Itapetininga/citros
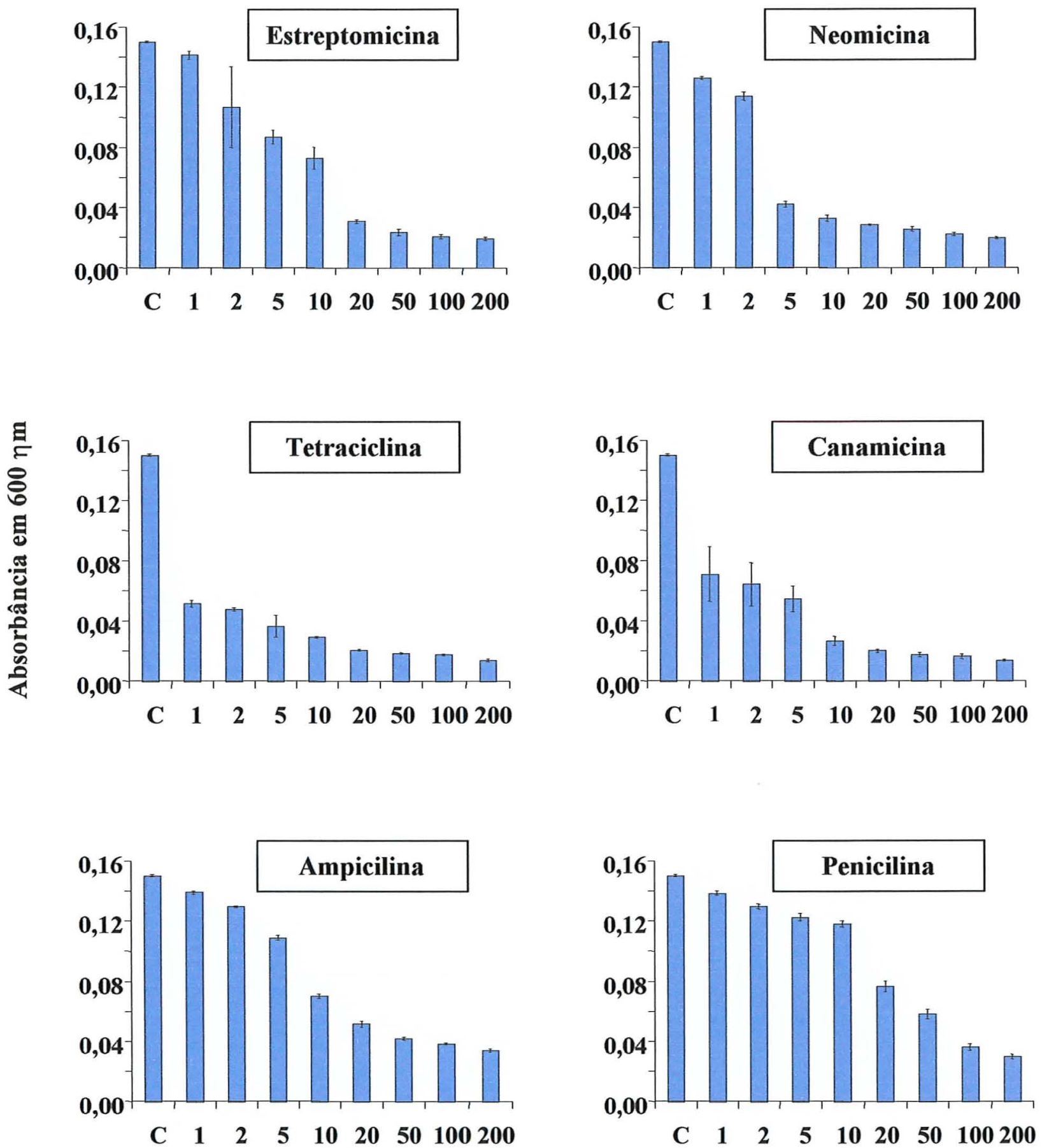

Concentração dos antibióticos $(\mu \mathrm{g} / \mathrm{mL})$

Figura 12. - Curvas de inibição do isolado de citros da região de Itapetininga à diferentes concentrações de antibióticos 
Isolado: Olímpia/citros
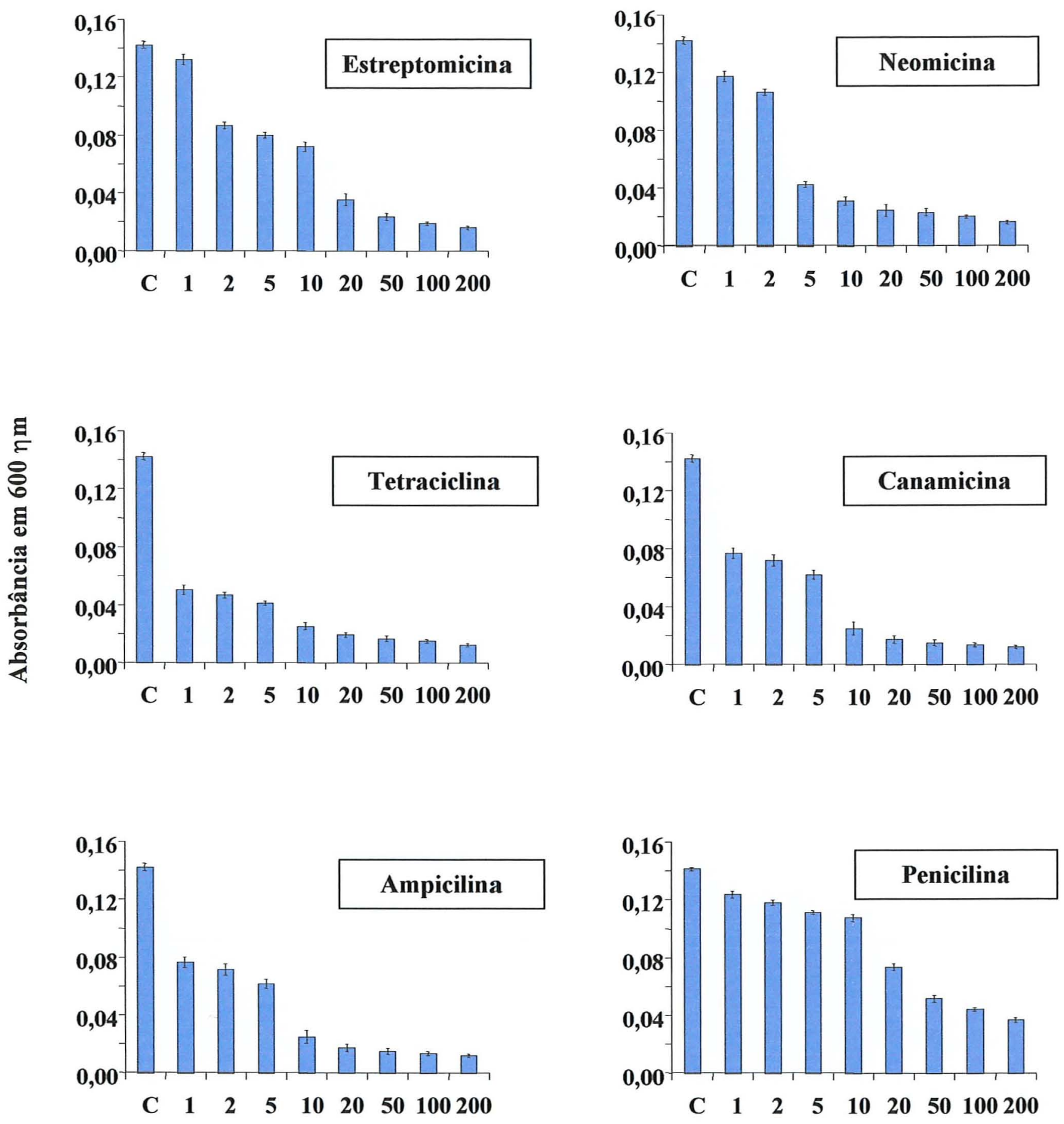

Concentração dos antibióticos $(\mu \mathrm{g} / \mathrm{mL})$

Figura 13. - Curvas de inibição do isolado de citros da região de Olímpia à diferentes concentrações de antibióticos 
Isolado: Colina/citros
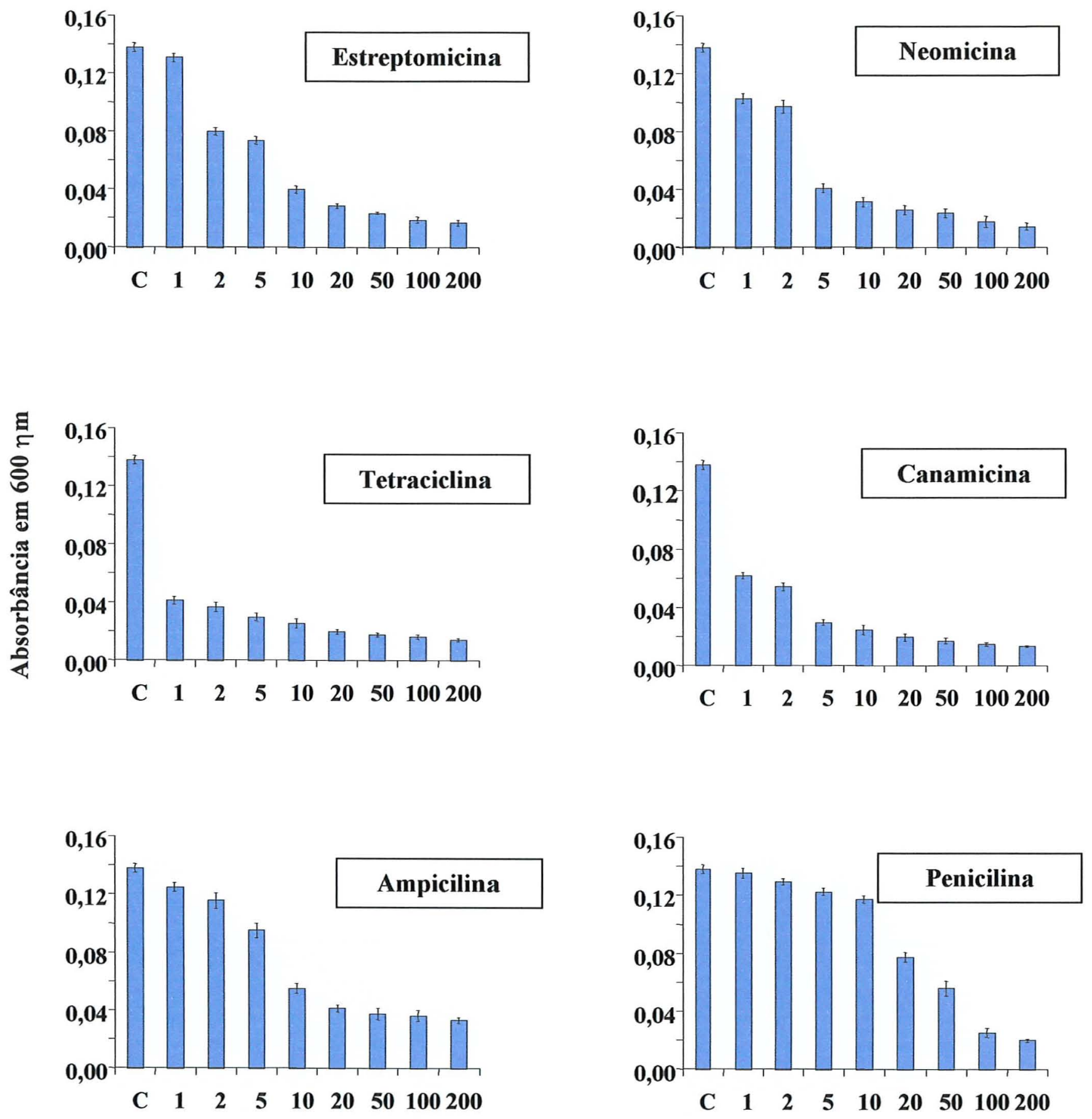

Concentração dos antibióticos $(\mu \mathrm{g} / \mathrm{mL})$

Figura 14. - Curvas de inibição do isolado de citros da região de Colina à diferentes concentrações dos antibióticos. 
Isolados: Novaes/citros
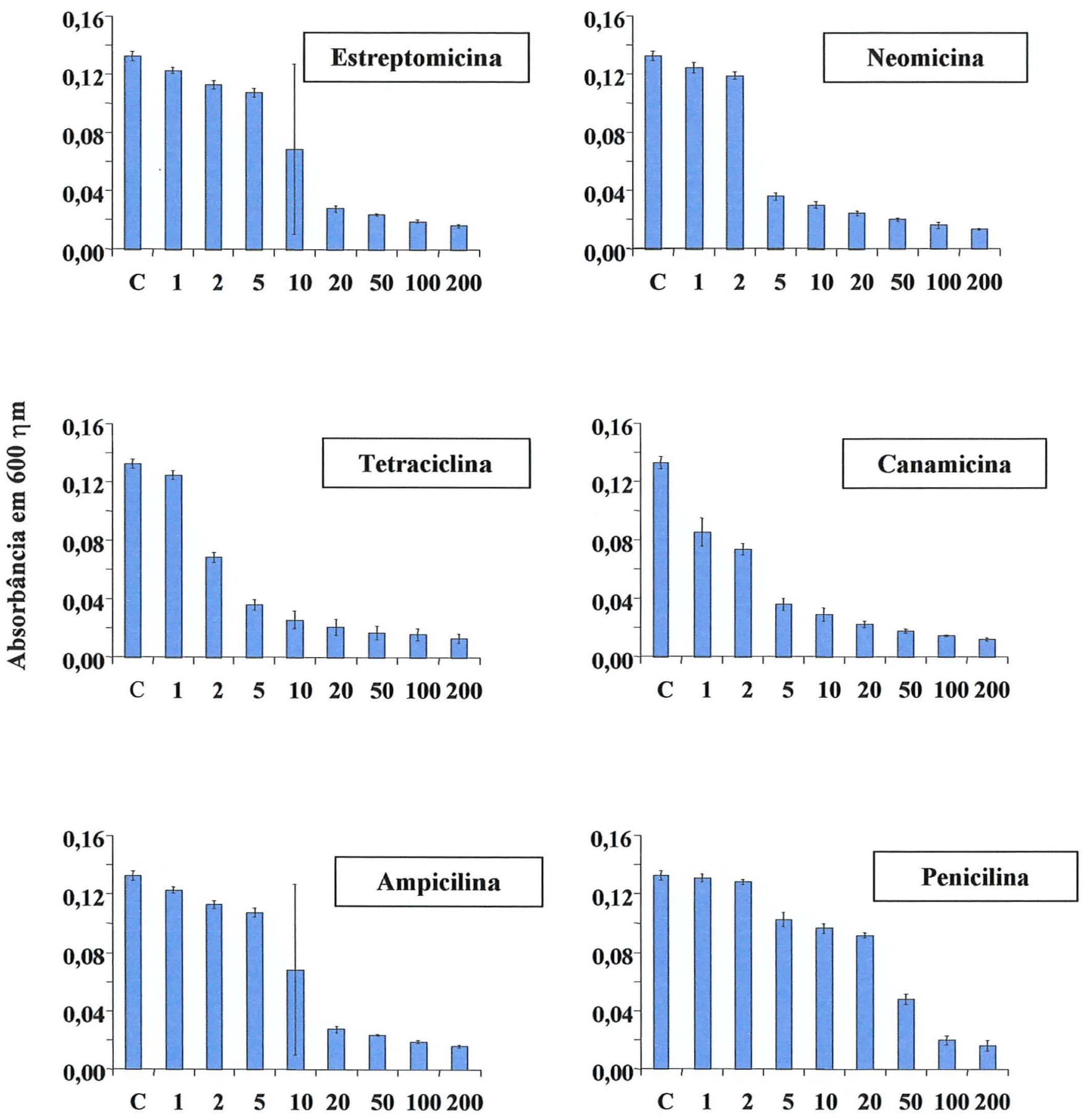

Concentração dos antibióticos $(\mu \mathrm{g} / \mathrm{mL})$

Figura 15. - Curvas de inibição do isolado de citros da região de Novaes à diferentes concentrações de antibióticos 
Isolado: Marília/café
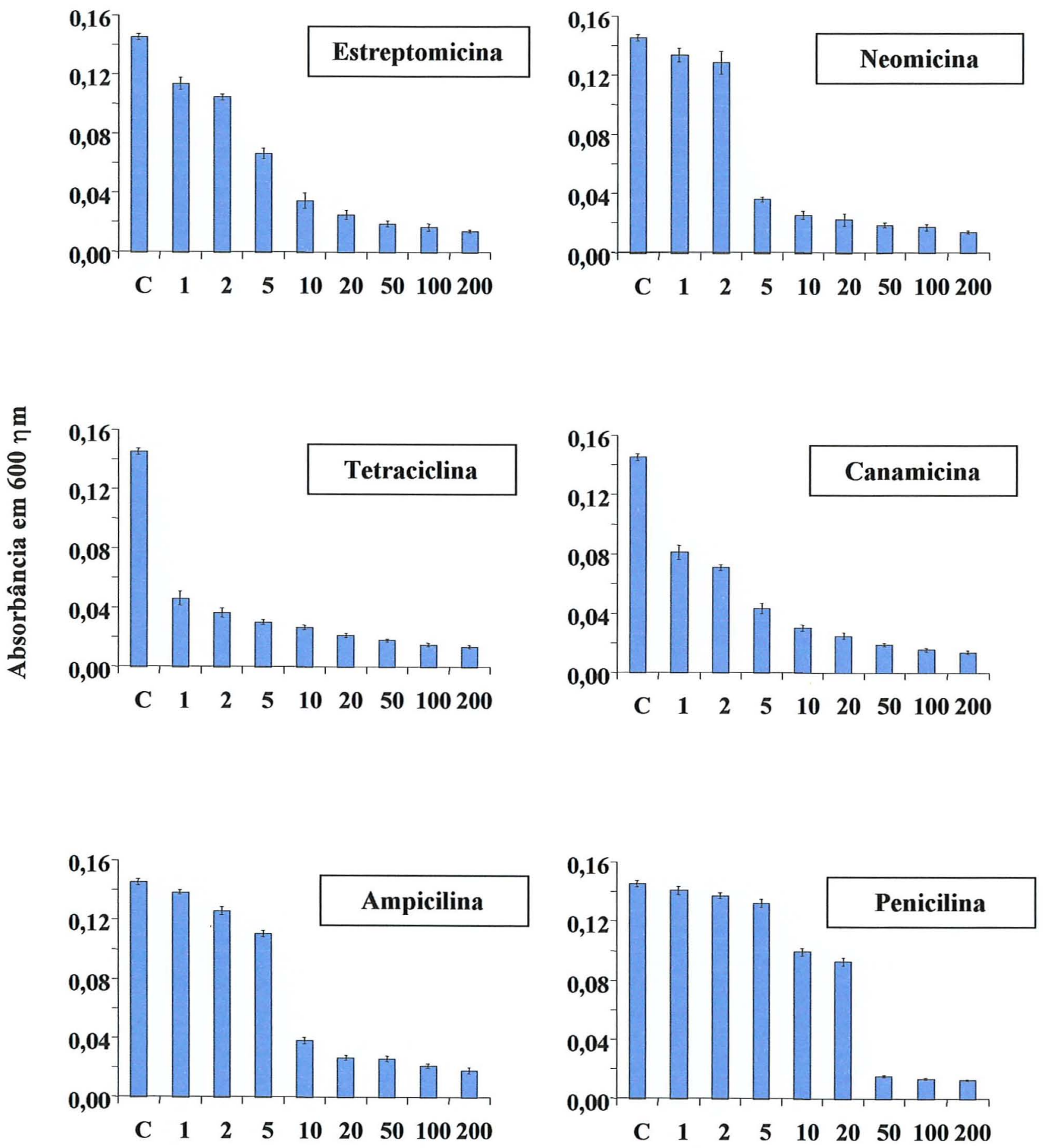

Concentração dos antibióticos $(\mu \mathrm{g} / \mathrm{mL})$

Figura 16. - Curvas de inibição do isolado de citros da região de Marília à diferentes concentrações de antibióticos. 
Isolado: EUA/Videira
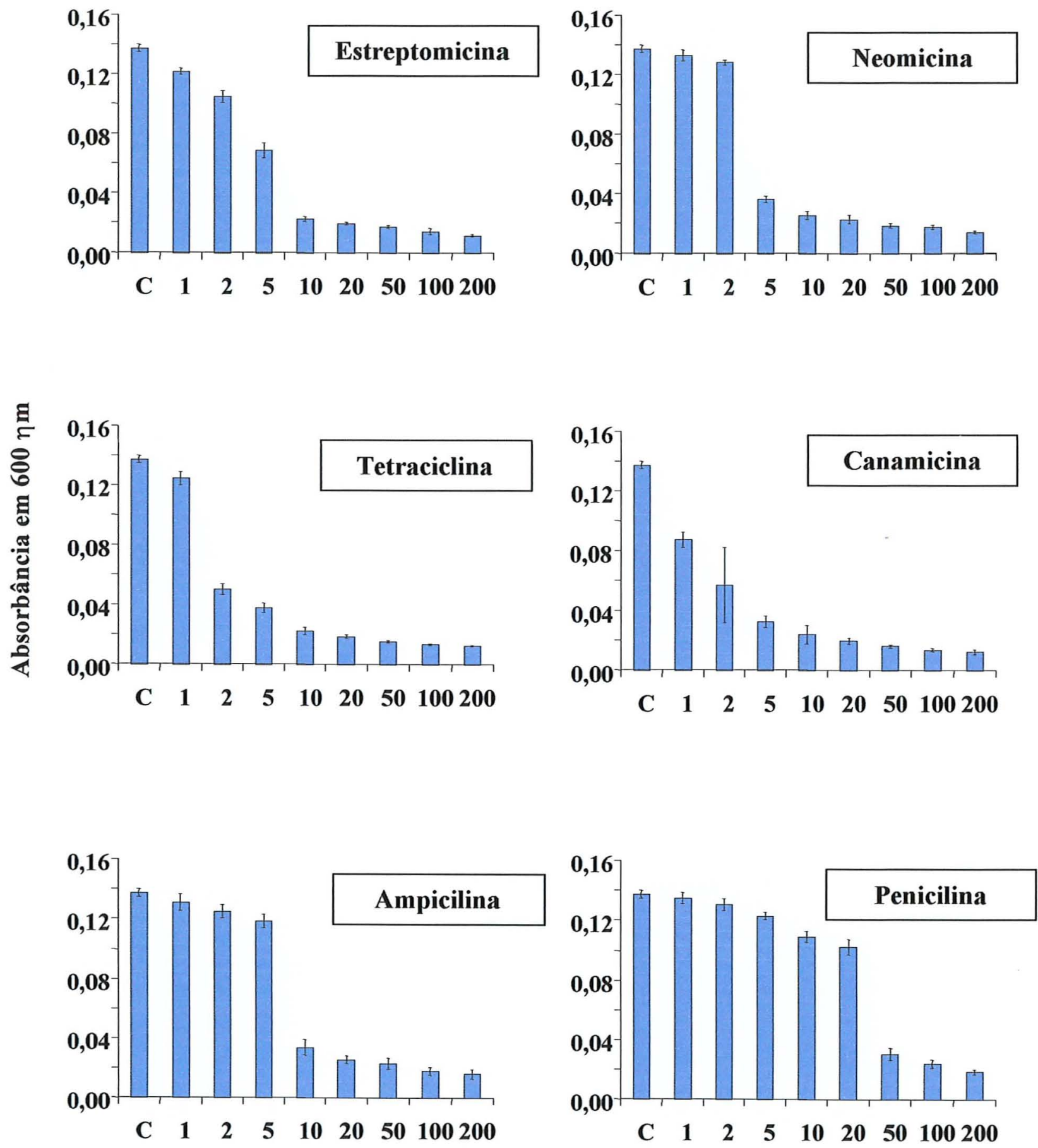

Concentração dos antibióticos $(\mu \mathrm{g} / \mathrm{mL})$

Figura 17. - Curvas de inibição do isolado de videira frente à diferentes concentrações de antibióticos 
Isolado: 9a5c/citros

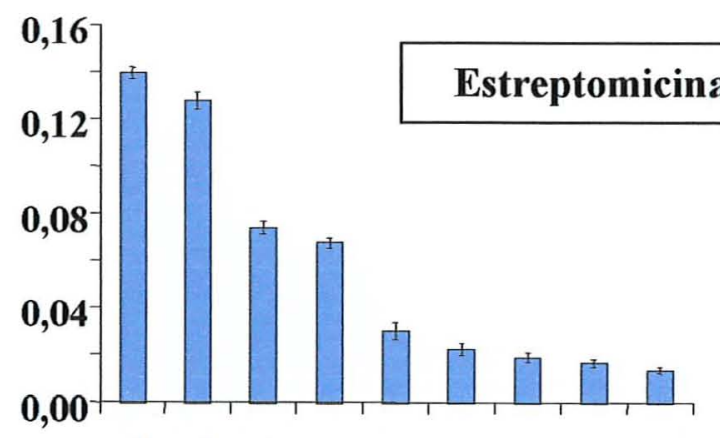

$\begin{array}{llllllllll}\text { C } & 1 & 2 & 5 & 10 & 20 & 50 & 100 & 200\end{array}$
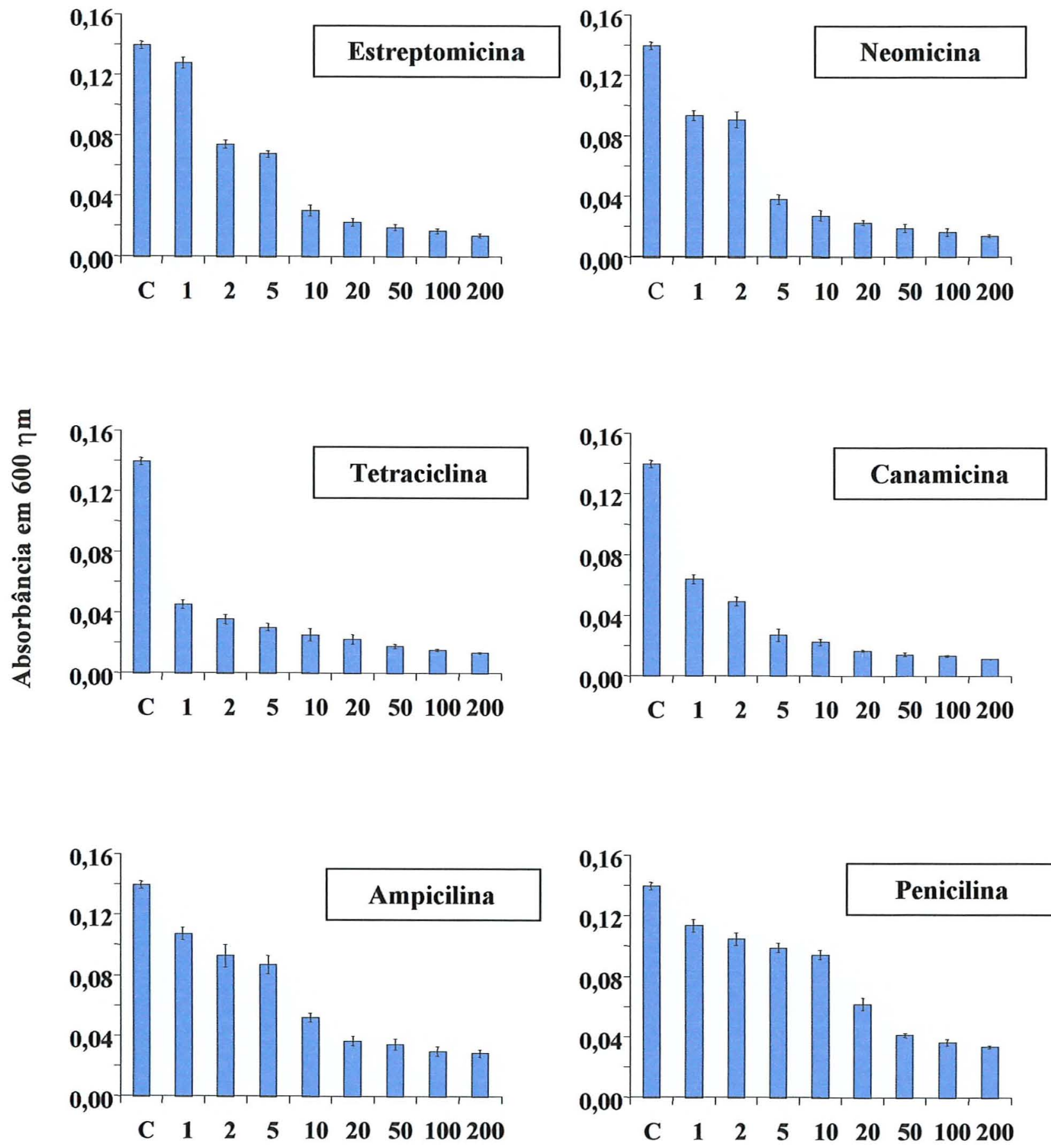

Concentração dos antibióticos $(\mu \mathrm{g} / \mathrm{mL})$

Figura 18. - Curvas de inibição do isolado 9a5c à diferentes concentrações de antibióticos 


\subsection{Interação "in vitro". entre $X$. fastidiosa e bactérias endofíticas de citros}

Os resultados da interação "in vitro" não demostraram antagonismo ou inibição de crescimento da $X$. fastidiosa, isolada de citros afetada pela CVC, por nenhum dos isolados bacterianos endofíticos testados (Pantoea agglomerans, Curtobacterium flaccumfaciens e Methylobacterium spp).

Entretanto, para os ensaios de interação entre a bactéria do gênero Methylobacterium spp houve estímulo de crescimento de $X$. fastidiosa, sendo este endofíticos o único a estimular crescimento o desta bactéria (Figura 19).

X. fastidiosa

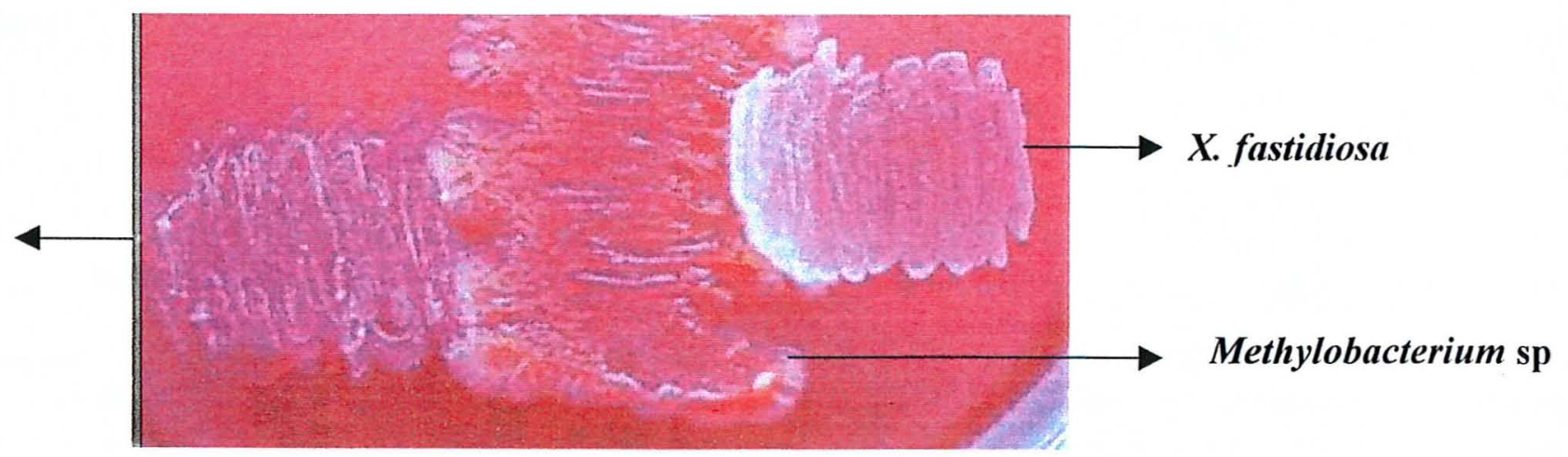

Figura 19. - Estímulo de crescimento da X. fastidiosa por Methylobacterium sp. 


\section{DISCUSSÃO}

A metodologia de isolamento descrita por Lima et al. (1998), mostrou-se adequada para Xylella fastidiosa de citros, sendo essa mesma técnica utilizada para o isolamento desta bactéria em cultura de café. Este fato foi confirmado por Miranda (1999) utilizando essa mesma técnica em citros.

Durante o isolamento notou-se que grande parte do experimento era perdido em função de contaminações, provavelmente acarretadas por microrganismos endofiticos presentes nas amostras, fato este não relatado pelos autores acima citados quando utilizando a referida técnica.

Para solucionar o problema de contaminações nos isolamentos, optou-se pela diluição do conteúdo xilemático após centrifugação, seguido de diluições em número de 10 que foram adequadas para reduzir a incidência de contaminantes.

Almeida (1999), utilizando a metodologia descrita por Hill \& Purcell (1995), para isolamento primário de X. fastidiosa, teve problemas de contaminação do extrato bruto durante $o$ isolamento, e da mesma forma recorreu à diluições para a eliminação dos contaminantes.

No isolamento primário por centrifugação e utilizando o meio de cultura PW constatou-se diferença de crescimento quando utilizava-se o meio líquido e o meio sólido, na forma líquida o crescimento era mais rápido enquanto para o sólido o tempo de incubação era maior para o surgimento de colônias. Carvalho (1999) utilizando esta mesma técnica para isolamento fez referência a um crescimento mais rápido em meio $\mathrm{PW}$ líquido quando comparado ao meio sólido. 
A técnica de isolamento primário de $X$. fastidiosa em ameixeira proposta por Uchibaba et al. (1992), quando aplicada para citros não mostrou resultados satisfatórios, pois o tempo de incubação para o aparecimento de colônias foi de cerca de 20 a 25 dias com o surgimento de colônias pequenas, além de contaminações com outros microrganismos de rápido crescimento. Com esta técnica não foi possível utilizar diluições para minimizar o surgimento de possiveis contaminantes endofíticos.

Leite et al. (1997), em estudos de hospedeiros alternativos de X. fastidiosa, também não obtiveram sucesso utilizando a metodologia descrita por Uchibaba et al. (1992). Os autores tiveram problemas de contaminações, mesmo após a esterilização da parte superficial do vegetal, impossibilitando o isolamento de $X$. fastidiosa em plantas invasoras por este método de detecção.

Entretanto, cabe salientar que a avaliação desta metodologia neste trabalho devese ao fato de Uchibaba et al. (1992) demonstrar que para o isolamento de $X$. fastidiosa em ameixeira, com sintomas de escaldadura das folhas, obtiveram sucesso.

Para isolamento em ameixeira Uchibaba et al. (1992) demostra que os resultados proporcionaram um maior desenvolvimento de colônias e maior taxa de recuperação da população bacteriana comparo com outros meios de cultura e técnicas.

A opção de cultivo da $X$. fastidiosa nos meios PW e BCYE em termos de eficiência relativa deve ser considerada em função do seu objetivo. Pois no meio PW é possível um tempo de incubação menor, cerca de 7 dias para o aparecimento de colônias, enquanto no meio BCYE cerca de 20 dias.

Quando realizava-se sucessivas transferências de $X$. fastidiosa por estrias nos meios de PW e BCYE, observava-se que no meio $\mathrm{PW}$ a viabilidade e o número de colônias caiam em relação ao $\mathrm{BCYE}$. Ao passo que no $\mathrm{BCYE}$ após o mesmo número de transferências obtinha-se maior massa bacteriana, contudo com maior tempo de incubação que no PW.

No presente trabalho, os seis "primers" selecionados para as reações de RAPD produziram 71 bandas polimórficas nos 16 isolados de citros, 2 de cafeeiro e um de videira. Em geral, o RAPD obtido dos isolados de citros demonstraram baixo 
polimorfismo, com exceção do isolado $9 \mathrm{a} 5 \mathrm{c}$ que demostrou varią̧ões nos padrões de bandas em relação aos outros isolados de citros. Em trabalho semelhante sobre análise de variabilidade genética Rosato et al. (1998) também relatam baixa variabilidade genética entre as linhagem $X$. fastidiosa isoladas de plantas cítricas.

Com base no dendograma foi possível constatar que os isolados provenientes de citros formam um grupo distinto dos isolados do cafeeiro e da videira. O grupo citros apresentou um coeficiente médio de similaridade de $72 \%$, possuindo uma pequena variabilidade dentro do próprio grupo, em que o isolado 9a5c apresentando um coeficiente de similaridade de $78 \%$ em relação aos demais isolados de citros.

Quanto aos isolados de cafeeiro e videira é possível colocá-los em grupos distintos ao dos citros, contudo o grupo cafeeiro parece demonstrar um menor polimorfismo em relação ao grupo videira quando comparados com o dos citros, pois o coeficiente médio de similaridade para os isolados de cafeeiro foi de $62 \%$ em relação ao dos citros. Análise por marcadores de PCR, utilizando os "primers" 272-2 int. e CVC-1 (Pooler \& Hartung, 1995a) específicos para X. fastidiosa causadora da CVC, também reforça a hipótese do grupo cafeeiro estar mais próximo do grupo citros, pois utilizando esses "primers" houve a mesma amplificação nos dois grupos e não ocorrendo para o de videira.

Lima et al. (1998) comparando linhagens de X. fastidiosa causadora da CVC e da Coffee Leaf Scorch (CLS), utilizando os "primers" 272-2 e CVC-1, observaram que os produtos de amplificação via PCR foram indiferentes para os isolados de cafeeiro e citros, apesar dos "primers" serem específico para X. fastidiosa causadora da CVC, reforçando os indícios de similaridade genética entre as linhagens isoladas de hospedeiros diferentes.

Costa et al., (2000) em estudo sobre polimorfismo genético de cinco linhagens da bactéria X. fastidiosa, agente causal da Clorose Variegada dos Citros, do Mal de Pierce em videira e queima da folha em ameixeira, sugerem uma pequena diversidade genética (coeficiente de similaridade de $87,2 \%$ ) entre bactérias isoladas de citros e cafeeiro e uma 
grande diversidade (coeficiente de similaridade $50-60 \%$ ) entre isolados de ameixeira do Brasil e de isolados de ameixeira e videira Norte Americana.

Os resultados dos antibiogramas pelo método da difusão em meio sólido mostraram-se adequados para uma análise qualitativa e mais rápida da sensibilidade aos antibióticos pela $X$. fastidiosa, pois o fator tempo quando se trata de um microrganismo fastidioso como a Xylella é de fundamental importância.

Utilizando o método Kirby-Bauer de antibiograma por difusão, foi possível categorizar todos os 10 isolados testados em resistentes a penicilina e sensiveis a canamicina, polimixina B, rifampcina, vancomicina, ampicilina e cloranfenicol. Miranda (1999) em estudos preliminares de sensibilidade a antibióticos pela X. fastidiosa, também utilizando o método Kirby-Bauer, obteve resultados semelhantes para penicilina, e polimixina, e diferentes para ampicilina dos obtidos no presente trabalho. Entretanto, o autor não cita o número médio de repetições empregadas no antibiograma bem como a origem dos isolados.

O meio de PW sólido permitiu satisfatoriamente a condução do antibiograma em pelo método da difusão, podendo ser visualizadas as formações de halos de inibição e não interferir pela presença do soro albumina bovina na ação dos antibióticos, pois trata-se segundo Chang \& Donaldson (1993) de um composto que possui entre outras funções a de sequestrar compostos inibidores no meio de cultura.

Os resultados obtidos no antibiograma em meio líquido utilizando a técnica de diluição dos antibióticos foram interpretados através de gráficos correlacionando a turbidez (absorbância em 600 ๆm) com as diferentes concentrações dos antibióticos, determinando a concentração mínima inibitória (MIC) no ponto onde ocorresse inibição de $50 \%$ ou mais de crescimento bacteriano.

$\mathrm{O}$ antibiótico que teve maior poder de inibição foi a tetraciclina, ocorrendo em baixa concentração $(1 \mu \mathrm{g} / \mathrm{mL})$. Hopkins \& Mortensen (1971) numa tentativa de confirmar que o agente causal da PD era de origem bacteriana, tratou plantas de videira afetada com tetraciclina, conseguindo assim a remissão dos sintomas nas plantas tratadas, evidenciando a susceptibilidade desta bactéria ao antibiótico. 
Diante dos resultados obtidos até o presente momento com os antibiogramas a tetraciclina foi o antibiótico eleito para uma tentativa de convivência da CVC através da antibióticoterapia. A eliminação do patógeno pode ser tentada utilizando-se, por exemplo, a tetraciclina, para o tratamento de borbulhas evitando-se o uso indiscriminado do antibiótico nessa estratégia de controle. Entretanto é preciso ressaltar que fatores limitantes do sucesso da antibióticoterapia podem existir, como: falta de padronização do antibiograma, levando a resultados geralmente de "falsa sensibilidade" e falha na escolha do antibiótico somada às características adequadas para evitar a fitotoxidez durante o tratamento.

Os isolados analisados quanto a sensibilidade à penicilina, mostraram-se resistentes a esse antibiótico tanto no antibiograma pelo método das diluições como pelo método da difusão. Bastonetes Gram-negativos formam um grupo com elevado grau de resistência aos antibióticos, podendo o espectro de sensibilidade variar de uma área geográfica para outra. (Petersdorf et al., 1961). Entretanto através dos dados obtidos neste trabalho foi possível ter uma idéia do padrão mais comum de sensibilidade para os isolados do gênero Xylella testados, onde os antibióticos: estreptomicina, neomicina, tetraciclina, canamicina, cloranfenicol, rifampicina, polimixina e ampicilina revelaram-se sensiveis, recaindo a resistência unicamente frente a penicilina.

Com o seqüenciamento completo do genoma da bactéria $X$. fastidiosa, também foi identificado um gene que codifica uma proteína de ligação a penicilina semelhante a $\beta$ lactamase, inativando à abertura do anel $\beta$-lactâmico desse antibiótico, explicando assim o mecanismo de resistência a esse antibiótico.

Após o seqüenciamento, o passo seguinte é o conhecimento da função dos genes identificados, principalmente, aqueles genes que possam estar envolvidos no processo de patogenicidade desta bactéria. Desta forma, foi lançado o projeto genoma funcional da $X$. fastidiosa pela FAPESP, que tem como objetivo o maior conhecimento da bactéria e da sua interação com vetor e o planta-hospedeiro.

Uma das estratégias mais utilizadas para se estudar a função de genes é a inativação gênica. Neste caso um gene que possa estar envolvido com a patogenicidade é 
alterado de tal forma que, sua expressão não ocorre. O procedimento é construir um gene sintético com um gene de resistência a um antibiótico interrompendo sua sequêencia codificadora, denominado assim de gene inativado.

Em estudo semelhante de função de gene, Duret et al. (1999) utilizaram a estratégia de inativação gênica em Spiroplasma citri, inativando o gene $s c m 1$, envolvido na motilidade deste fitopatógeno. Por esta estratégia foi possível identificar que esse gene não tem importância no processo patogênico deste microrganismo.

Os gene estudado por inativação gênica tem que ser introduzido na bactéria para que substitua o gene selvagem, presente no genoma da bactéria. Com o gene selvagem substituído pelo gene sintético inativado, sua expressão não ocorre. Todo esse procedimento gera uma linhagem mutante da bactéria em questão.

Este mutante pode ser agora testado no processo patogênico e a função do gene na patogenicidade pode ser avaliada. Nessa estratégia é necessário que se desenvolva um sistema de transformação que permita a introdução do gene sintético inativado, que por sua vez modificará o gene alvo. Uma das estratégias mais utilizadas com esse objetivo é a construção de plasmídios contendo um gene de resistência a um antibiótico. Este plasmídio é então transformado em células bacterianas que sejam sensiveis ao referido antibiótico. Uma vez transformadas, estas células são crescidas em meio de cultura contendo este antibiótico. Aquelas colônias que crescerem serão transformadas pelo plasmídio e logo são candidatas para o estudo de patogenicidade.

A maior parte dos plamídios utilizados na construção de vetores para sistema de transformação utilizam genes de resistência a alguns antibióticos testados no presente trabalho, sendo observado genes de resistência como dos plasmídios pUC18-19 (ampicilina) (Sambrook et al., 1989) pBR322 (tetraciclina) (Sambrook et al., 1989), pUCK4 (canamicina e neomicina) (Sambrook et al., 1989), desta forma os plasmídios citados poderão ser utilizados na construção de vetores para transformar $X$. fastidiosa em virtude da sensibilidade demonstrada por esta bactéria em relação a esses antibióticos.

Os testes de interação "in vitro" com as bactérias endofiticas Pantoea agglomerans, Curtobacterium flaccumfaciens e Methylobacterium sp. não demonstraram 
nenhum efeito de inibitório sobre o crescimento de $X$. fastidiosa. Entretanto, observou-se um estímulo no crescimento de $X$. fastidiosa quando interagindo com Methylobacterium sp. Araújo (2000), em estudo da comunidade bacteriana de citros e sua interação com $X$. fastidiosa observou que a bactéria endofitica Curtobacterium flaccumfaciens foi isolada principalmente de plantas cítricas assintomática quanto à $\mathrm{CVC}$, enquanto Methylobacterium spp foi isolada principalmente de plantas com sintomas característicos da CVC.

Os resultados da interação "in vitro", assim como os dados de isolamento de bactérias endofíticas, realizados por de Araújo (2000), sugerem que a bactéria endofítica Methylobacterium sp., estando em alta freqüência em plantas afetadas pela CVC, pode estar de alguma forma estimulando o desenvolvimento da $X$. fastidiosa no processo de colonização da planta hospedeira. 


\section{CONCLUSÕES}

- A metodologia por centrifugação é mais adequada para isolamento de $X$ fastidiosa de citros.

- O meio PW é mais recomendado para reduzir o tempo de incubação para $X$. fastidiosa, mas para obtenção de maior massa bacteriana o meio BCYE foi mais adequado.

- A análise de variabilidade genética demostrou a existência de grupo citros, cafeeiro e videira. Os isolados de citros formam um grupo homogêneo com alto grau de similaridade. $\mathrm{O}$ isolado $9 \mathrm{a} 5 \mathrm{c}$, dentro do grupo citros, demostrou variação nos padrões de bandas em relação aos demais isolados do mesmo grupo.

- O meio de cultura PW para realização de antibiogramas proporcionou resultados satisfatórios, ressaltando-se a inocuidade do soro albumina bovina frente aos antibióticos.

- Os antibióticos estreptomicina, neomicina, canamicina, tetraciclina, ampicilina, polimixina B, rifampcina e cloranfenicol inibiram o crescimento de $X$. fastidiosa. Em relação ao antibiótico penicilina não houve inibição.

- O resultado do seqüenciamento da $X$. fastidiosa veio confirmar que esta bactéria possui resistência ao antibiótico penicilina. 
- Os resultados dos antibiogramas indicam quais os antibióticos que poderão ser usados no desenvolvimento de um sistema de transformação para $X$. fastidiosa.

- Os resultados da interação "in vitro" sugerem que a bactéria endofitica de citros Methylobacterium sp. estimula o crescimento da $X$. fastidiosa 


\section{REFERÊNCIAS BIBLIOGRÁFICAS}

AGRIOUS, N.G. Sintomas da Clorose Variegada dos Citros, Plant Pathology $4^{\mathrm{a}}$.ed Academic Press. 1997.

ALMEIDA, R.P.P. Multiplicação e movimentação de Xylella fastidiosa em mudas de Citrus sinensis e sua eficiência de aquisição e inoculação por vetores. Piracicaba, 1999. 57p. Dissertação (Mestrado) - Escola Superior de Agricultura "Luiz de Queiroz", Universidade de São Paulo.

AMATO NETO, V.; LEVI, G.C.; LOPES, H.V.; MENDONÇA, J.S.; BALDY, J.L.S. Antibióticos na prática médica. 3 ed. Savier, São Paulo. 209p. 1985.

ARAÚJO, W.L. Isolamento, identificação e caracterização genética de bactérias endofiticas de porta-enchertos de citros. Piracicaba, 1996. 85p. Dissertação (Mestrado) Escola Superior de Agricultura "Luiz de Queiroz", Universidade de São Paulo.

ARAÚJO, W.L. A comunidade bacteriana endofitica de citros e sua Interação com Xylella fastidiosa, agente causal da clorose variegada dos citros (CVC). Piracicaba, 2000. 131p. Tese (Doutorado) - Escola Superior de Agricultura "Luiz de Queiroz", Universidade de São Paulo.

AUFAUVRE-BROWN, A.; COHEN, J.; HOLDEN, D.W. Use Randomly Amplified Polymorphic DNA markes to distinguish isolated of Aspegillus fumigatus. Journal of 
Clinical Microbiology, v.30, p.2991-2993, 1992.

AUSUBEL, F.M.; BRENT, R.; KINGSTON, R.E.; MOORE, D.D.; SEIDMAN, J.G.; SMITH, J.A.; STRUHL, K. Short Protocols in Molecular Biology. New York. $2^{\text {a }}$. ed. John Wiles \& Sons, v.1, p.2-10, 1992.

ASTOLFI F $\square$, S.; AZEVEDO, J.L.; AZEVEDO, M. O. Novas técnicas de recombinação em microrganismos: a engenharia genética pela tecnologia do DNA recombinante. In: AZEVEDO, J.L. (Coord.). Genética de Microrganismo em Biotecnologia e Engenharia Genética. Piracicaba: FEALQ, 1985. cap.6, p.43-59.

AZEVEDO, J.L. Genética de Microrganismos. Goiás: Universidade Federal Goiás, 1998. $478 \mathrm{p}$.

AZEVEDO, J.L.; MACCHERONI Jr., W.; PEREIRA, J.O.; ARAÚJO, W.L. 2000. Endophytic microorganisms: a review on insect control and recent advances on tropical plants. EJB: Electronic Journal of Biotechnology [online], 15 April 2000, 3: [cited 05 May 2000]. Available on the Web: http://www.ejb.org/content/vol3/issue1/full3/4. ISSN: 0717-3458.

BAUER, A.W.; ROBERTS, C. E. \& KIRBY, W.M.M. Single disc antibiotic versus multiple disc and plate dilution techniques for antibiotic sensitivity testing. In: Antibiotics Annual 1959/60. New York, Medical Encyclopedia. p. 574-580, 1960.

BAYLES, K.W. The bactericidal action of penicillin: new clues to an unsolved mystery. Trends in Microbiology. v.8, p.274-278, 2000.

BELL, C. R., DICKIE, G.A.; HARVEY, W.L.G.; CHAN, J.W.Y.F. Endophytic bacteria in grapevine. Canadian journal of Microbiology, v.41, p.46-53, 1995. 
BECKMANN, J.S. Oligonucleotideo polymorphisms: a new tool genomic genetics. Biotechnology, v.6, p.1061 - 1064, 1988.

BERETTA, M.J.G.; HARAKAVA, R.; CHAGAS, C.M.; DERRICK, K.S.; BARTHE, G.A.; CECCARDI, T.L.; LEE, R.F.; PARADELA, O.; SUGIMORI, M.; RIBEIRO, I.A. First report of Xylella fastidiosa in coffee. Plant Disease, n.80, p. 821, 1996.

BERETTA, M.J.G.; BARTHE, G.A.; CECCARDI, T.L.; LEE, R.F.; DERRICK, K.S. A survey for strains of Xylella fastidiosa in citrus variegated chlorosis and citrus blight in Brazil Plant Disease, 1997.

BERISHA, B.; CHEN, Y.D.; ZHANG, G.Y.; XU, B.Y.; CHEN, T.A. Isolation of Pierce's disease bacteria from grapevines in Europe. European Journal of Plant Pathology, v.104, p.427-433, 1998.

BRUNSKILL, E.W.; BAYLES, K.W. Identification of LytSR-regulated genes from Staphylococcus aureus. Journal of Bacteriology. v.178, p.5810-5812, 1996.

CAMPOS, C.E.O.P.; AZEVEDO, J.L.; COSTA, S.O.P. Aspectos genéticos e clínicos da resistência bacteriana a drogas. Ars. Curandi, v.9, p.16-36, 1976.

CARLOS, E.F.; LIMA, J.E.O.; ROBERTO, S.R.; COUTINHO, A. Evolução da Clorose Variegada dos Citros em duas propriedades no Estado de São Paulo. Fitopatologia Brasileira, n.22 (Suplemento) resumo n.9, p.233, 1997.

CARVALHO, I.F. Isolamento, cultivo "in vitro" da Xylella fastidiosa e sua extração do sistema vegetativo de Citrus. Araraquara, 1999.67p. Dissertação (Mestrado) - Instituto de Química, Universidade Estadual Paulista "Júlio de Mesquita Filho". 
CHANG, C.J.; DONALDSON, R.C. Xylella fastidiosa: cultivation in chemically defined medium. Phytopathology, v.83, p.192, 1993.

CHANG, C.J; ROBACKER, C.D.; LANE, R.P. Further evidence for the isolation of Xylella fastidiosa on nutrient agar from grapevines showing Pierces's disease symptoms. Canadian Journal of Plant Pathology, v.12, p.405-408, 1990.

CHEN, J.; C.J.; CHANG, R.L.; JARRET. Plasmids from Xylella fastidiosa strains. Canadian Journal of Microbiology, v.38, p.993-995, 1992a.

CHEN, J.; CHEANG, C.J.; JARRET, R.L; GAWEL, N. Genetic variation among Xylella fastidiosa strains. Phytopathology, v.82, p.973-977, 1992b.

CHEN, J, LAMIKANRA, O.,CHANG, C.J., HOPKINS, D.L. Randomly amplified polymorphic DNA analysis of Xylella fastidiosa Pierce's disease and oak leaf scorch pathotypes. Applied and Environmental Microbiology, v.61, p.1688-1690, 1995.

CHEN, X.; LINE, R.F.; LEUNG, H. Relationship between virulence variation and DNA polymorphism in Puccinia striiformis. Phytopathology, v.55, p.681-687, 1965.

COCHRAN, L.C.; HUTCHINS, L. Phony Virus diseases of stones fruit. Handbook. n.437, p.96-102, 1976.

COLETA FILHO, H.D.; CARLOS, E.F.; MACHADO, M.A. Distribuição da bactéria Xylella fastidiosa em plantas de laranja. Fitopatologia Brasileira, n.22 suplemento, p. 234, 1997. (resumo, 13).

CORREL, J.C.; RHOADS, D.D.; GUEERBER, J.C. Examination of mitochondrial DNA 
restriction fragment length polymorphisms, DNA fingerprints, and randomly amplified polymorphic DNA of Colletorichum orbiculare. Phytopathology, v.83, p.1199-1204, 1993.

COSTA, P.I.; FRANCO, C.F; MIRANDA, V.S.; TEIXEIRA, C.D.; HARTUNG,J.S. Strains of Xylella fastidiosa rapidly distinguished by arbitrarily primed-PCR. Current Microbiology, v.40, p.279-282, 2000.

CROWHURST, R.N.; HAWTHORNE, B.T.; RIKKRINK, E.H.A; TEMPLETON, D.M. Differentiation of fusarium solani f. sp. Cucurbitae races 1 and 2 by random amplification of polymorphic DNA. Current Genetic, v.20, p.391-396, 1991.

DAVIS, M.J.; PURCELL, A.H.; THOMSON, S.V. Pierce's disease of grapevines: isolation of the causal bacterium. Sciense, v.199, n.4323, p.75-77, 1978.

DAVIS, M.J.; PURCELL, A. H.; THOMPSON, S.V. Isolation media for the Pierce's disease bacterium. Phytopathology, v.70, p.425-429, 1978.

DAVIS, M.J.; FRENCH, W.J.; SCHAAD, N.W. Axenic culture of bacteria associated with phony disease of peach and plum leaf. Current Microbiology, n.6, p.309-314, 1981a.

DAVIS, M.J.; WHITCOMB, R.F; GILLASPIE Jr., A. G. Fastidious bacteria of plant vascular tissue and invertebrates (including so-called rickettsia-like bacteria). In: STARR, M.P.; STOLP, H.; TRÛPER, H.G.; BALOWS, A.; SCHLEGEL, H.G. (Ed.). The prokaryotes. A handbook on habitats, isolation and identification of bacteria. USA, p.2172-2188, $1981 b$.

DEMEKE, T.; ADAMS, R.P.; CHIBBAR, R. Potential taxonomic use of random 
amplified polymorphic DNA (RAPD): a case study in Brassica. Theoretical and Applied Genetics, v.84, p.990-994, 1992.

DE NEGRI, J.D. Clorose variegada dos citros: nova anomalia afetando pomares em São Paulo e Minas Gerais. Com. Tec. n 82, Ext. Rural, Cati, Campinas. p.6, 1990.

DONADIO, L.C., MOREIRA, C.S. Clorose variegada dos citrus. In: Edição Comemorativa do $15 \square$ Aniversário da Estação Experimental de Citricultura de Bebedouro, Jaboticabal. p.27. 1997.

DUIJFF, B.J., GIANINAZZI-PEARSON, V.; LEMANCEAU, P. Involvement of the outer membrane lipopolysaccharides in the endophytic colonization of tomato roots by biocontrol Pseudomonas fluorescens strain WCS417r. New Phytologist, v.135, p.325$334,1997$.

DURET, S.; DANET, J.; GARNIER, M.; RENAUDIN, J. Gene disruption through homologous recombination in Spiroplasma citri: an scm 1 - disrupted motility mutant is pathogenic. Journal of Bacteriology. v.181, p.7449-7456, 1999.

FAVA NETTO, C. Antibiograma. In: LACAZ, C.S. (org.) Antibióticos. $3^{\mathrm{a}}$ ed. São Paulo. Ed Edgar Blucher Ltda. e Ed. USP, p.221-233. 1975.

FARBER, J.M., ADDISON, C.J. RAPD typing for distinguishing species and strains in the genus Listeria. Journal of Applied Bacteriology, v.77,p.242-250, 1994.

FERREIRA, M.E.; GRATTAPAGLIA, D. Introdução ao uso de marcadores RAPD e RFLP em análise genética. Brasilia: EMBRAPA/CENARGEN, p.219., 1995.

FLEMING, A. On the antibacterial action of culture of a Penicillium whit special 
reference to their use in isolation of Bacillus influenzae. Journal Experimental Pathology, v. 10, p.226-236, 1929.

FOOLAD, M.R.; JONES, R.A; RODRIGUEZ,R.L. RAPD markers for constructing intraspecific tomato genetics maps. Plant Cell Reports, v.12, p.293-297, 1993.

FRASER, C.M. \& FLEISCHMANN R.D. Strategies for whole microbial genome sequencing and analysis. Electrophoresis, v.18, p.1207-1216, 1997.

FRY, S.M.; HUANG, J.S.; MILHOLLAND, R.D. Protease production by grape strains of Xylella fastidiosa. Phytopathology, v.82, p.1094, 1992 (Abstr.)

FUKUOKA, S.; HOSAKA, K.; KAUIMA, O. Use of random amplified polymorphic DNAs (RAPDs) for identification of rice acessions. Japanese Journal of Genetics, v.67, p.243-252, 1992.

FUNGARO, M.H.P.; VIEIRA, M.L.C. Aplicações da PCR em ecologia molecular. In: MELO, I.S.; AZEVEDO, J.L. (Eds). Ecologia microbiana. Jaguariúna: EmbrapaCNPMA, 1998. cap. 8, p. 205-227.

GARNIER, M., CHANG, C.J., ZREIK, L., ROSSETTI, V., BOVÉ, J.M. Citrus variegated chlorosis: serological detection Xylella fastidiosa, the bacterium associated with the disease. In: CONFERENCE OF THE INTERNATIONAL ORGANIZATION OF CITRUS VIROLOGISTS, IOCV, 12, India. Proocedings..., p. 301-305, 1993.

GIBBS, R.A. Hares and tortoises in the race to sequence the human genome: expectations and realities. Trends in Genetics v.13, p.381-383, 1997.

GIRÃO, D.M.; BANDO,S.Y.; GIIRÃO, V.B.; MOREIRA-FILHO; C.A; 
FRACALANZZA, S.E.L.; TRABULSI, L.R.; NETTO, V.M. Characterization of typical and atypical enteropathogenic Escherichia coli (EPEC) strains of the classical O55 serogroup by RAPD analysis. Brazilian Journal of Microbiology, v.30, p.365-368, 1999.

GLIENKE, C. Variabilidade genética no fungo endofitico Guinardia citricarpa Kiely detectada por RAPD. Curitiba, 1995. 115p. Dissertação. (Mestrado) - Universidade Federal do Paraná.

GOHEEN, A.C.; NYLAND, G.; LOWE, S.K. Association of a rickettsialike organism whit Pierce's disease for grapevine and alfalfa dwarf and heat therapy of the disease in grapevines. Phytopathology, v.63, p.341-345, 1973.

GROSSER, J.W.; GMITTER JR, F.G. Protoplast fusion and citrus improvement. Plant Breeding Reviews, New York, v.8, p. 339-374, 1990a.

HALLMANN, J.; QUADT-HALLMANN, A.; MAHAFFEE W.F.; KLOEPPER, J.W. Bacterial endophytes in agricultural crops. Canadian Journal of Microbilogy, v.43, p.895-914, 1997.

HARAKAVA, R.M.; BERETTA, M.J.G. Obtenção de anticorpos para Xylella fastidiosa, agente causal da clorose variegada dos citros, a partir de ovos postos por galinhas poedeira imunizadas. Laranja, v.15, n.1, p.87-95, 1994.

HARRISON, S.P.; MYRTON, L.R.; SKOT, L.; DYE, M.; CRESSWELL, A. Characterization of Rhizobium isolated by amplification of DNA polymorphisms using random primers. Canadian Journal of Microbiology, v.38, p.1009-15, 1992.

HARTUNG, J.S.; BERETTA, M.J.G.; BRALANSKY, R.H.; SPISSO, J.; LEE, R.F. 
Citrus variegated chlorosis bacterium: axenic culture, pathogenicity, and serological relationships whit other strains of Xylella fastidiosa. Phytopathology, v.64, p.591-597, 1994.

HAYDEN, H.L.; PEGG, K.G.; AITKEN, E.A.B.; IRWIN, J.A.G. Genetic relationships as assessed by molecular markers and cross-infections among strains of Colletotrichum gloesporioides. Australian Journal of Botany, v.42, p.9-18, 1994.

HEWITT, W.B. A transmissible disease of grapevines. (Abstr.) Phytopathology, v.29, p.10, 1939.

HILL, B.L.; PURCELL, A.H. Mutiplication and movement of Xylella fastidiosa within grapevine and four other plants. Phytopathology, v.85, p.1368-1372, 1995.

HOPKINS, D.L.; MORTENSEN, J.A. Suppression of Pierce's disease symptoms by tetracycline antibiotics. Plant Disease Reporter, v.55, p.610-612, 1971.

HOPKINS, D.L.; MOLLENHAUER, H.H. Rickettsia-like bacterium associated with Pierce's disease of grapes. Science, v.179, p.298-300, 1973.

HOPKINS, D.L. Variability of virulence in grapevine among isolated of Piece's disease bacterium. Phytopathology, v.74, p.1395-1398. 1984.

HOPKINS, D.L. Physiological and pathological characteristics of avirulent strains of the bacterium that causes Pierce's disease of grapevine. Phytopathology. v.75, p.713-717, 1985.

HOPKINS, D.L. Xylella fastidiosa xylem - limited bacterial pathogen of plants. Annual Review of Phytopathology, v.27, p.271-290, 1989. 
IZIOKA, E. E. K.; SOUZA, N.L.; MACHADO, M.; LOPES, C.R. Caracterização morfológica, patogênica e molecular de Colletotrichum gloeosporioides, agente causal da podridão floral dos citros. Fitopatologia Brasileira (suplemento), v.20, p. 379, 1995.

JAMES, E.K.; REIS, V.M.; OLIVARES, F.L., BALDANI, J.I.; DOBEREINER. Infection of sugar cane by the nitrogen-fixing bacterium Acetobacter diazotrophicus. Journal of Experimental Botany, v.45, p.757-766, 1994.

JAMES, E.K. \& OLIVARES, F.L. Infection and colonization of sugar cane and other graminaceous by endophytic diazotrophs. Critical Reviews in Plant Science, v.17, p.77$119,1998$.

JAWETZ, E.G.; COLEMAN, J.B.; KEMPE, H.C. A laboratory test for bacterial sensitivity to combinations of antibiotics. American Journal of Clinic, v.25, p.1016$1031,1955$.

JULIUS, H.W.; GAIKHORST, G. The effects of combining antibiotics. Antibiotics \& Chemother, v.8, p.287-286, 1958.

KAMPER, S.M.; FRENCH, W.J.; DEKLOET, S.R. Genetic relationships of some fastidious xylem-limited bacteria. International Journal Systematic Bacteriology, n.35, p.185-188, 1995.

LACAZ, C.S. Antibióticos. Conceituação. Agentes produtores. Aspectos microbiológicos. Classificação. Súmula dos principais antibióticos utilizado na prática médica. In: LACAZ, C.S. (Ed.) Antibióticos. $3^{\text {a }}$ ed. São Paulo. Ed Edgar Blucher Ltda. e Ed. USP, p.1-54. 1975 
LEE, R.F.; DERRICK, K.S.; BERETTA, M.J.G; CHAGAS, C.M.; ROSSETTI, V. Citrus variegated chorosis: a new destructive disease of citrus in Brazil. Citrus Industry, v.72, p.10-13, 15. 1991.

LEE, R.F.; BERETTA, M.J.G.; HARTUNG, J. H.; HOOKER, M.E.; DERRICK, K.S. Citrus variegated chlorosis: confirmation of Xylella fastidiosa as the agent causal agent. Summa Phytopathologica, v.19, n.2, p.123-125, 1993.

LEE, R.F.; BERETTA, M.J.G.; DERRICK, K.S.; HOOKER, M.S. Development of a serological assay for citrus variegated chlorosis a new disease of citrus in Brazil. Proceedings of Florida State Horticultural Society, v.105, p.32-35, 1992.

LEITE Jr, R.P.; LEITE, R.M.V.B.C. Associação de Xylella fastidiosa com clorose variegada dos citros. Summa Phytopathologica (resumo), v.17, p.7, 1991.

LEITE, R.M.V.B.C; JACOMINO, A.P. Ocorrência de clorose variegada dos citros no Estado do Paraná. Summa Phytopathologica, v.19, p.35, 1993.

LEU, L.S.; SU, C.C. Isolation, cultivation and pathogenicity of Xylella fastidiosa, the causal bacterium of pear leaf schorch in Taiwan. Plant Disease, v.77, p.642-646, 1993.

LI, W.B. Estudo de resistência ou tolerância à clorose variegada dos citros. Tese (Doutorado - Faculdade de Ciências Agrárias e Veterinárias, Universidade Estadual Paulista, Jaboticabal. 1997. 107p.

LIMA, J.E.O. A pesquisa sobre amarelinho no Fundecitrus. Laranja, v.16, p.137-144, 1995.

LIMA, J.E.O.; MIRANDA, V.S.; COUTINHO, A.; ROBERTO, S. R.; CARLOS, E.F. 
Distribuição de Xylella fastidiosa no cafeeiro, nas regiões cafeeiras e seu isolamento in vitro. Fitopatologia Brasileira, v.21, p.392-393, 1996.

LIMA, J.E.O.; MIRANDA, V. S.; HARTUNG, J.S.; BRLANSKY, R.H.; COUTINHO, A.; ROBERTO, S.R.; CARLOS, E.F. Coffe Leaf Scorch Bacterium: Axenic Culture, Pathogenicity, and Comparison whit Xylella fastidiosa of Citrus. Plant Disease, v.82, p.94-97, 1998.

LOPES, J.R.S.; BERETTA, M.J.G.; HARAKAVA, R.; ALMEIDA, R.P..P.; KRUGNER, R.; GARCIA Jr. A confirmação da transmissão por cigarrinha do agente causal da clorose variegada dos citros. Fitopatologia Brasileira (resumo) v.21, p.343, 1996.

LOUREIRO, M.F. Caracterização de estirpes por técnicas moleculares: o uso dos métodos de PCR e RAPD. In: HUNGRIA, M.; ARAUJO, R.S. Manual de Métodos Empregados em estudos de Microbiologia Agrícola. EMBRAPA, Brasília, 1994, p.183199.

MACHADO, M.A.; CARUSO, E.; QUAGGIO, J.A.; LAGOA, A.M.M.A.; TICELLI, M.; FURLANI, P.R. Trocas gasosas e relações hídricas em laranjeiras com Clorose Variegada dos Citros. Revista Brasileira de Fisiologia Vegetal., v.6, p.53-57, 1994.

MACHADO, M.A.; COLETTA FILHO, H.D.;TARGON, M.L.P.N.; POMPEU JR, J. Genetic relationship of mediterranean mandarins (Citrus deliciosa Tenore) using RAPD marks Euphytica, v.92, p.321-326, 1996.

MALAVOLTA, E. et al. Nova Anomalia dos citros: estudos preliminares. Laranja, v.11, v.1, p. 15-18, 1990. 
MAHAFFEE, W.F.; KLOEPPER, J.W.; VAN VUURDE, J.W.L.; VAN DER WOLF, J.M.; AND VAN DEN BRINK, M. Endophytic colonation of Phaseolus vulgaris by Pseudomonas fluorescens strain 89b-27 and Enterobacter asburiae strain JM22. In : Improving plant productivity in rhizosphere bacteria. M. H. Ryder, P. M. Stephens, \& G. D. Bowen (Eds.). CSIRO, Melbourne, Australia, p.180. 1997.

MANULIS, S.; KOGAN, N.; REUVEN, M.; BEM-YEPHET, Y. Use of the RAPD technique for identification of Fusarium oxysporum f. sp. dianthi from carnation. Phytopathology, v. 84, p.98-101, 1994.

MARTIN-KEARLEY, J.; GOW, J.A.; PÉLOQUIN, M.; GREER, C.W. Numerical analysis and the application of random amplified polymorphic DNA polymerase chain reaction to the differentiation of Vibrio strains from a seasonally cold ocean. Canadian Journal of Microbiology, v.40, p.446-445, 1994.

MEGNEGNEAU, P.; DEBEST, F.; HOCKSTRA, R.F. Genetic variability and related in the complex group of black Aspergillus based on random amplification of polymorphic DNA. Current Genetics., v.23, p.323-329, 1993.

MENEGUCCI, L.L.P.; PAIVA, L.V.; SOUTO, R.F.; CARVALHO, S.A.; MARINHO, C.S.; AMARAL, A.M.; SOUZA, M. Alterações fisico-químicas de frutos de laranjeira 'Valência' com sintomas de clorose variegada dos citros. Revista Brasileira de Fruticultura v.17, p.153-155, 1995.

MINSAVAGE, G.V.; THOMPSON, C.M.; HOPINKS, D.L.; LEITE, R.M.V.B.C.; STALL, R.E.D. Development of polymerase chain reaction protocols for detection of Xylella fastidiosa in plant tissue. Phytopathology, v.84, p.456-461, 1994.

MIRANDA, V.S. Clorose Variegada dos Citros: Estudos quanto ao cultivo, isolamento, 
identificação, teste de sensibilidade a agentes antimicrobianos e caracterização sorológica para a bactéria Xylella fastidiosa. Araraquara, 1998. 71p. Dissertação (Mestrado) Instituto de Química, Universidade Estadual Paulista "Júlio de Mesquita Filho".

M'PIGA, P.; BÉLANGER, R.R.; PAULITZ, T.C., BENHAMOU, N. Increased resistance to Fusarium oxysporum f. sp. radicis-lycopersici in tomato plants treated with the endophytic bacterium Pseudomonas fluorescens strains 63-28. Physiological and Molecular Plant Pathology, v.50, p.301-320, 1997.

MULLIS, K.; FALLONA, F. Specific synthesis of DNA "in vitro" via a polymerase catalyses chain rection. Methods Enzymology. v.55, p.335-350, 1987.

NEVES, E.M. O mundo citrícola em discussão. Gazeta Mercantil/Planalto Paulista, São Paulo, 10 jun. 1999.p.2.

NICHOLSON, P.; REZANOOR, H.N.; SU, H. Use of random amplified polymorphic DNA (RAPD) analysis and genetic fingerprinting to differentiate isolates of race $\mathrm{O}, \mathrm{C}$ and of Bipolaris maydis. Journal of Phytopathology, v.139, p.261-267, 1993.

PETERSDORF, R.G.; HOOK, E.W.; CURTIN, J.A.; GROSSBERG, S.E. The antimicrobial sensitivity of Gram-negative pathogens. Johns Hopkins. Hospital, v. 108, 48-59, 1961.

PETERSDORF, R.G., PLORDe, J.J. - The usefulness of "in vitro" sensitivity test in antibiotic therapy. Annual Review of Medical., v.14, p.41-56, 1963.

POOLER, M. R.; HARTUNG, J.S. Especific detection and indetification of Xylella fastidiosa strains causing citrus variegated chlorosis. Current Microbiology, v.31, p.377-381, 1995a. 
POOLER, M.R.; HARTUNG, J.S. Genetic relationships among strains of Xylella fastidiosa from RAPD-PCR data. Current Microbiology, v.31, p. 134-137, 1995 b.

POOLER, M.R.; HARTUNG, J.S.; FENTON, R.G. Sequence analysis of a 1296nucleotide plasmid from Xylella fastidiosa. Microbiology Letters, v.155, p.217-222, 1997.

PURCELL, A.H.; FINLAY, A H. Evidence for noncirculative transmission of Pierce's disease bacterium by sharpshooter leafhoppers. Phytopathology, v.69, p.393-395, 1979.

PURCELL, A.H.; HOPKINS, D.L. Fastidious xylem-limited bacterial pathogen. Annual. Review of Phytopathology, v.34, p.131-151, 1996.

PURCELL, A.H. Xylella fastidiosa, a regional problem or global threat?. Journal of Plant Pathology, v.79, p.99-105, 1997

QUADT-HALLMANN, A. \& KLOEPPER, J. W. Immunological and localization of the cotton endophyte Enterobacter asburiae JM22 in different plant species. Canadian Journal of Microbiology, v.42, p.1144-1154, 1996.

QUADT-HALLMANN, A.; BENHAMOU, N. \& KLOEPPER, J. W. Bacterial endophytes in cotton: mechanism of entering the plant. Canadian Journal of Microbiology, v.43, p.577-582, 1997a.

QUADT-HALLMANN, A.; HALLMANN, J. \& KLOEPPER, J.W. Bacterial endophytes in cotton: location and interation with other plant associadet bacteria. Canadian Journal Microbiology, v.43, p.254-259, 1997b.

QUAGGIO, J.A. Distúrbios nutricionais em citros afetados por CVC. Ata da $1^{\mathrm{a}}$ Reunião 
do Grupo de Trabalho sobre a CVC, 1988. Secretaria de Agricultura.

RAJU, B.C.; WELLS, J.M.; NYLAND, G.; BRLANKSKY, R.H.; LOWE, S.K. Plum leaf seald: isolation, culture and pathogenicity of causal agent. Phytopathology, v.72, p.1460-1466, 1982.

RAVEN, J.A. Phytophages of xylem and phloem: a comparison of animal and plant sapfeeders. Advances in Ecology Research, v.13, p. 135-234.

REINHOLD-HUREK, B. \& HUREK, T. Life in grasses: diazotrophic endophytes. Trends in Microbiology, v.6, p.139-144, 1998.

ROBERTO, S.R.; COUTINHO, A.; LIMA, J.E.O.; MIRANDA, V.S.; CARLOS, E.F; Transmissão de Xylella fastidiosa pelas cigarrinha Dilobopterus costalimai, Acrogonia terminalis e Oncometopia facialis em citros Fitopatologia Brasileira, v.21, p.517-518, 1996.

RODRIGUES NETO, J.; BERIAM, L.O.S.; KOMORI, N. Caracterização de isolados de Xylella fastidiosa de citros por eletroforese em gel de poliacrilamida/sds. Summa Phytopathologica (resumo), v.18, p.46, 1993.

ROMEIRO, R.S.; OLIVEIRA, J.R.; MOURA, A.B.; BARBOSA, L.S.; SOARES, F.M.; PERES, F.; SIMÕES, A.R. Significado taxonômico da sensibilidade diferencial de fitobactérias a antibióticos. Fitopatologia Brasileira (abstract), v 18, p.277, 1993.

ROSATO, Y.B.; NETO, J.R.; MIRANDA, V.S.; CARLOS. E.F.; MANFIO, G.P. Diversity of a Xylella fastidiosa population from Citrus sinensis affected by citrus variegated chlorosis in Brazil. Systematic and Applied Microbiology, v.21, p.593-598, 1998. 
ROSSETTI, V.; DE NEGRI, J.D. Clorose variegada dos Citros - revisão. Laranja, v.11, p.01-14, 1990.

RUPPEL, S.; HECHT-BUCHHOLZ, C.; REMUS, R.; ORTMANN, U.; SCMELZER, R. Settlement of diazotrophic, phytoeffective bacterial strain Pantoea agglomerans on and within winter wheat: an investigation using ELISA and transmission electron microscopy. Plant and Soil, v.145, p.261-273, 1992.

SAIKI, R.K.; SCARF, S.; FALLONA, F.A.; MULLIS, K.B.; HORN, G.T.; ERLICH, H.A.; ARNHEIM, N. Enzymatic amplification of globin genomic sequences and restriction site analysis for diagnostic of sickle cell anemia. Science, v.230, p.1350-1354, 1985.

SAIKI, R.K.; GELFAND, D.H.; STOEFELL, S.; SHCARF, S.J.; HIGUCHI, G.; HORN, G.T; MULLIS, K.B; ERLICH, H.A. Primer-directed enzymatic amplification of DNA with a thermostable DNA polymerase. Science v.239, p.487-491, 1988.

SAMBROOK, J.; FRITSCH, E.F.; MANIATIS, T. Molecular cloning: a laboratory manual. 2.ed. New York: Cold Spring Harbor Laboratory, 1989.

SANDERY, M., COBLE, J., MCKERSIE-DONNELLEY, S. Random amplified polymorphic DNA (RAPD) profiling of Legionella pneumophila. Letters in Applied Microbiology, v.19, p.184-187, 1994.

SHARMA, V.K.; NOWAK, J. Enhancement of verticillium wilt resistance in tomato transplants by in vitro co-culture of seedlings with a plant growth promoting rhizobacterium (Pseudomonas sp. strain PsJN). Canadian Journal of Microbiology, v.44,p.528-536, 1998. 
SIMPSON, A.J.G.; REINACH, F.C. et al. ARRUDA, P. The genome sequence of plant pathogen Xylella fastidiosa. Nature. v.406, p.151-159, 2000.

SOUSA, A.O. Bactérias endofiticas de Milho (Zea mays L.) e sua variabilidade genética analisada por RAPD. Piracicaba, 1996. 83p. Dissertação (Mestrado) - Escola Superior de Agricultura "Luiz de Queiroz", Universidade de São Paulo.

SPINOSA, H.S.; GORNIAK, S.L.; BERNARDI, M.M. Agentes Antimicrobianos. Rio de Janeiro. Ed. Guanabara-Koogan, p.333-386, 1996.

STANIER, R.Y.; INGRAHAM, J.L; PAINTER, P.R. The Microbiol World. Englewood Cliffs, Prentice Hall, 689p. 1986.

STEPHAN, R.; SCHARAFT, H.; UNTERMANN, F. Characterization of Bacillus licheniformis with the RAPD technique (randomly amplified polymorphic DNA). Letters in Applie Microbiology, v.18, p.260-263, 1994.

STURZ, A.V. \& MATHESON, B.G. Populations of endophytic bacteria which influence host-resistance to Erwinia-induced bacterial soft rot in potato tubers. Plant and Soil, v.184, p.265-271, 1996.

STURZ, A.V.; CHRISTIE, B.R.; MATHESON, B.G. Associations of bacterial endophyte populations from red clover potato crops with potential for beneficial allelopathy. Canadian Journal of Microbiology, v.44, p.162-167, 1998.

TAVARES, W. Manual de antibióticos para o estudante de medicina. Atheneu, Rio de Janeiro, 348p. 1988.

TUBELIS, A. Difusão temporal da clorose variegada dos citros em pomares comerciais 
de laranja doce no Estado de São Paulo e Minas Gerais, Brasil In: ENCONTRO SOBRE AMARELINHO DOS CITROS (CVC), Piracicaba. 21-23, 1992

TUBELIS, A.; RODRIGUES NETO, J.; BERETTA, M.J.G. Primeira constatação da anomalia clorose variegada dos citros no Estado de Goiás. Summa Phytopathologica (resumo), v.19, p.46, 1993.

UCHIBABA, E.Y.; LEITE JÚNIOR, R.P.; LEITE, R.M.V.B.C Avaliação de meios de cultura gerais e específicos para cultivo de Xylella fastidiosa isoladas de ameixeira com escaldadura da folha. Fitopatologia Brasileira v.17, p.252-257, 1992.

VASCONCELOS, M.J.V; MACHADO, M.A.; ALMEIDA; HENNING, A.A.; BARROS, E. G.; MOREIRA, M.A. Differentiation of Colletotrichum truncatum isolates by random amplified polymorphi DNA. Fitopatologia Brasileira, v.19, p.520-523, 1994.

WANG, G.; WHITTAM, T.S.; BERG, D.E. RAPD (Arbitrary primer) PCR is more sensitive than multilocus enzyme electrophoresis for distinguishing related bacterial strains. Nucleic Acids Research, v.21, p.5930-5933, 1993.

WELLS, J.M.; RAJU, B.C.; NYLAND, G.; LOWE, S.K. Medium for isolation and growth of bacteria associated with plum leaf scald and phony peach diseases. Applied and Environmental Microbiology, v.42, p.357-363, 1981.

WELLS, J.M., RAJU, B.C., MYLAND, G. Isolation, cultivation and pathogenicity of bacterium causing phony disease of peach. Phytopathology, v. 73, p.895-862, 1983.

WELLS, J.M.; RAJU, B.C.; JUNG, H.Y.; WEISBURG, W.G.; MANDELCO-PAUL, L.; BRENER, D.J. Xylella fastidiosa gen nov., sp. nov. gram-negative, xylem limited fastidious plant bacteria related to Xanthomonas spp. International Journal of 
Systematic Bacteriology, v.37, p.136-143, 1987.

WELSH, J.; McCLELLAND, M. Fingerprinting using PCR with arbitrary primers. Nucleic Acids Research., v. 18, p.7213-7218, 1990.

WILLIAMS, J.G.K.; KUBELIK, A.R.; LIVAK, K.J.; RAFALSKI, J.A.; TINGEY, S.V. DNA polymorphisms amplified by arbitrary primers are useful as genetic markes. Nucleic Acids Research., v.18, p.6531-6535, 1990.

WILLIAMS, J.G.K.; HANAFEY, M.K.; RAFALSKI, J.A.; TINGEY, S.V. Genetic analysis using random amplified polymorphic DNA markes. Methods in Enzymology., v.218, p.704-740, 1993.

WINKLER, A.J.; HEWITT, W.B.; FRAIZER, N.W.; FREITAG, J.H. Pierce's disease investigations. Hilgardia, v.19, p.207-264, 1949.

YAP, I.; NELSON, R.J. Winboot: a program for performing boostrap analysis of binary data to determine the confidence limits of UPGMA-based dendogram. IRRI Discussion Paper Series, v.14, 1996. 